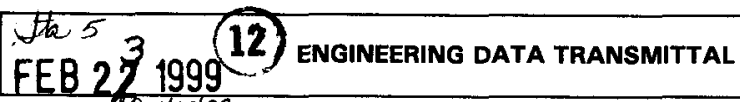 ap $2 / 2399$
}

\section{To: (Receiving Organization)}

Distribution

5. Proj/Prog./Dept./Div:

TRU Project

8. Originator Remarks:

This EDT is to release the documentation for the TRU Project to

Engineering Eiles for retention and retrieval purposes

\section{Receiver Remarks:}

3. From: (Originating Organization)

TRU Waste Program

6. Design Authority/Design Agent/Cog. Engr.:

$\mathrm{N} / \mathrm{A}, \mathrm{N} / \mathrm{A}$, TM Greager
4. Related EDT No::

$\mathrm{N} / \mathrm{A}$

7. Purchase Order No.

$\mathrm{N} / \mathrm{A}$.

9. Equip./Component No.:

$\mathrm{N} / \mathrm{A}$

10. System/Bldg/Facility

$\mathrm{N} / \mathrm{A}$

12. Major Assm. Dwg. No.:

N/A

13. Permit/Permit Application No.:

$\mathrm{N} / \mathrm{A}$

14. Required Response Date:

$N / A$

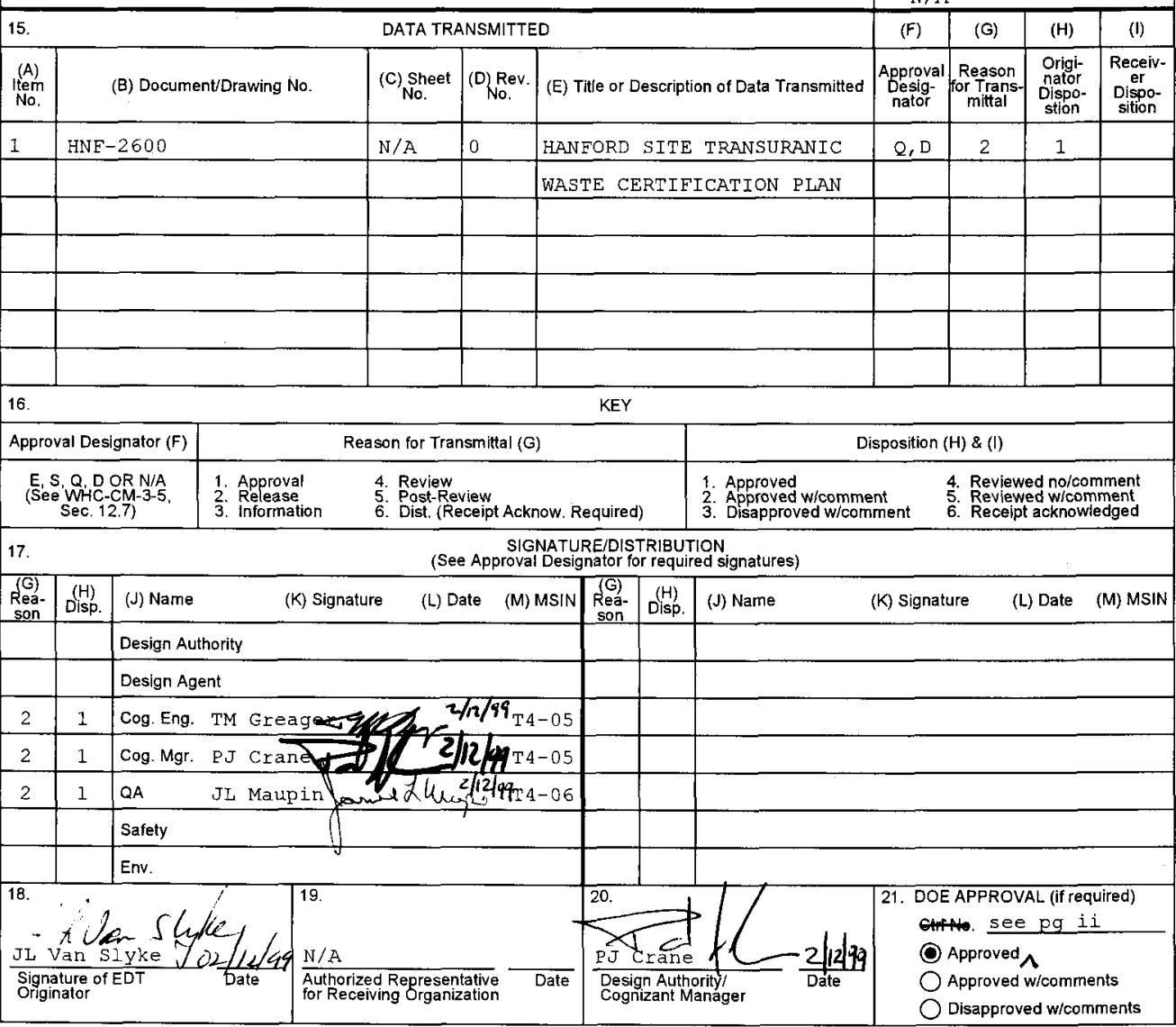

BD-7400-172-2 (10/97) 


\title{
HANFORD SITE TRANSURANIC WASTE CERTIEICATION PLAN
}

\author{
TM Greager \\ Waste Management Federal Services of Hanford, Inc. \\ P.O, Box 700, Richland, WA 99352 \\ U.S. Department of Energy Contract DE-AC06-96RL13200

\begin{tabular}{|c|c|c|}
\hline $\begin{array}{l}\text { DT/ECN: } \\
\text { rg Code: } \\
\text { \&R Code : }\end{array}$ & $\begin{array}{l}\text { EDT- } 625622 \\
32 B 00 \\
\text { EW02J126 }\end{array}$ & $\begin{array}{l}\text { UC: } 506 \\
\text { Charge Code: } \\
\text { Total Pages: }\end{array}$ \\
\hline
\end{tabular}

Key Words: Certification Plan, TRU, CAO, WIPP

Abstract: The Hanford Site Transuranic Waste Certification Plan establishes the programmatic framework and criteria within which the Hanford site ensures that contact-handled TRU wastes can be certified as compliant with the WIPP WAC and TRUPACT-II SARP.

* Kevlar is a registered trademark of E.I. du Pont de Nemours and Company, wilmington, DE.

*Oil-Dri is a registered trademark of Oil-Dxi Corporation, Chicago, IL

TRADEMARK DISCLAIMER. Reference herein to any specific commercial product, process, or service by trade name, trademark, manufacturer, or otherwise, does not necessarily constitute or imply its endorsement, recommendation, or favoring by the United States Government or any agency thereof or its contractors or subcontractors.

printed in the united States of America. To obtain copies of this document, contact: Document Control Services, P.O. Box 950, Mailstop H6-09, Richland WA 99352, Phone (509) 372-2420; Fax (509) 376-4989.
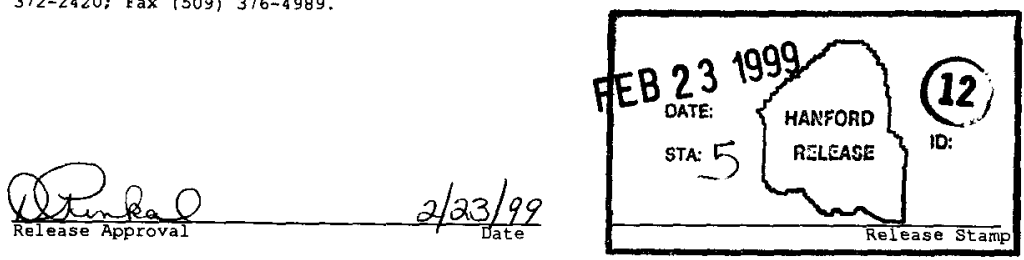

\section{Approved for Public Release}




\section{HANFORD SITE TRANSURANIC WASTE CERTIFICATION PLAN \\ HNF-2600 / Revision 0}

November 10,1998

Project No. 5065.01.0002

Prepared by:

Benchmark Environmental Corporation 4501 Indian School Road NE, Suite 105

Albuquerque, New Mexico 87110

Prepared under Subcontract No. MRC-SLD-A34726 for:

Waste Management Federal Services of Hanford, Inc.

P.O. Box 700

Richland, Washington 99352 


\section{HANFORD SITE TRANSURANIC} WASTE CERTIFICATION PLAN

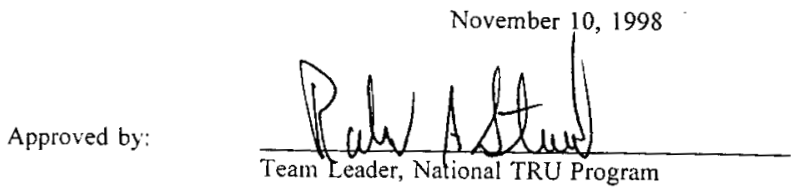

Approved by:

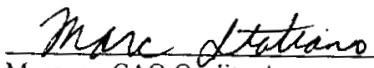

Manager, CAO Quality Assurance

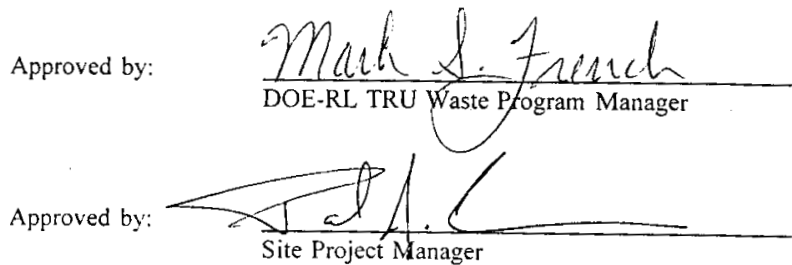

Site Project Manager

Approved by:

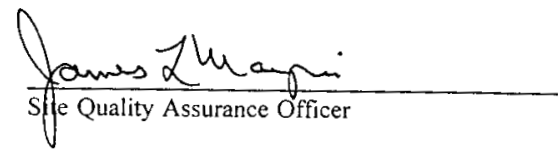

Approved by:

Approved by:
Date: $12 / 10 / 98$

Date: $12 / 10 / 97$

Date: $12 / 7 / 98$

Date: $14 / 20 / 58$

Date: $11 / 20 / 98$

Date: $11 / 20 / 9 p$ 
HNF-2600 Revision 0

\section{CONTENTS}

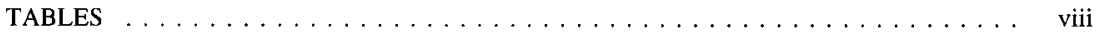

FIGURES $\ldots \ldots \ldots \ldots \ldots \ldots \ldots \ldots \ldots \ldots \ldots \ldots \ldots \ldots \ldots$

ACRONYMS AND ABBREVIATIONS $\ldots \ldots \ldots \ldots \ldots \ldots \ldots \ldots \ldots \ldots$

DEFINITIONS $\ldots \ldots \ldots \ldots \ldots \ldots \ldots \ldots \ldots \ldots \ldots \ldots \ldots \ldots \ldots \ldots \ldots \ldots$

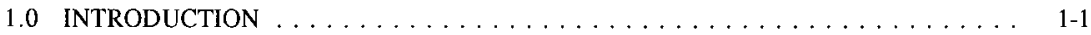

2.0 CERTIFICATION PROGRAM ORGANIZATION AT THE HANFORD SITE $\ldots \ldots \ldots$

2.1 ORGANIZATION AND RESPONSIBILITIES $\ldots \ldots \ldots \ldots \ldots \ldots \ldots \ldots \ldots . \ldots . \ldots \ldots$

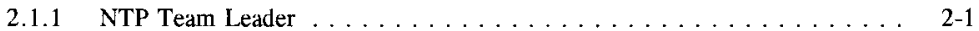

2.1.2 DOE-Richland Waste Programs Division . . . . . . . . . . . . . 2-1

2.1.3 FDH TRU Program Integration Manager . . . . . . . . . . . . . 2-1

2.1.4 Waste Management Services Project Manager . . . . . . . . . . . . . 2-1

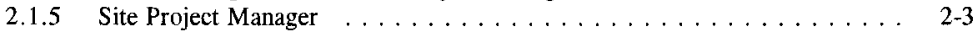

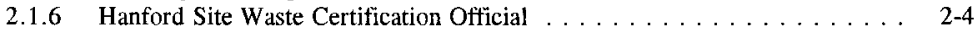

2.1.7 Hanford Site Quality Assurance Officer . . . . . . . . . . . . . . . 2-4

2.1.8 Hanford Site Transportation Certification Official . . . . . . . . . $2-5$

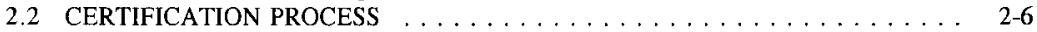

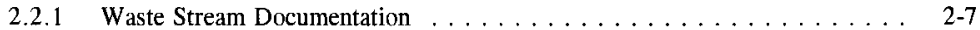

2.2.2 Acceptable Knowledge Documentation . . . . . . . . . . . . . . . 2-14

2.2.3 Waste Characterization and Certification Data Reporting .......... 2-14

2.3 CERTIFICATION PROGRAM DOCUMENT CONTROL AND RECORDS

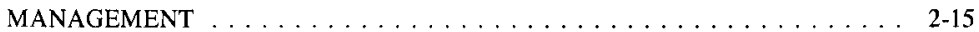

3.0 COMPLIANCE PLAN FOR WIPP WAC $\ldots \ldots \ldots \ldots \ldots \ldots \ldots \ldots \ldots \ldots$

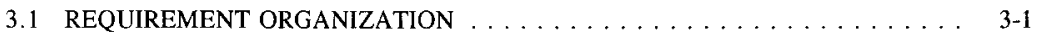

3.2 CONTAINER AND PHYSICAL PROPERTIES CRITERIA AND

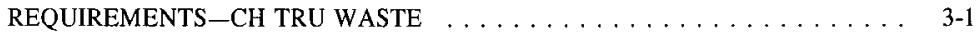

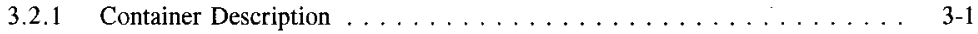

3.2 .1 .1 Requirements . . . . . . . . . . . . . . . . . 3-1

3.2.1.2 Compliance and Verification ................ 3-2

3.2.2 Container/Assembly Weight and Center of Gravity . . . . . . . . . . 3-3

3.2 .2 Requirements . . . . . . . . . . . . . . . . . . 3-3

3.2.2.2 Compliance and Verification .............. 3-4

3.2.3 Removable Surface Contamination (Payload Containers) . . . . . . . . . . . 3-4

3.2.3.1 Requirements . . . . . . . . . . . . . . . . . . . . 3-4

3.2.3.2 Compliance and Verification $\ldots \ldots \ldots \ldots \ldots \ldots \ldots . \ldots \ldots$ 3-4

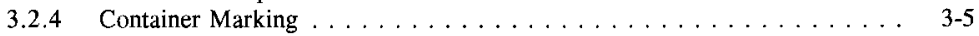

3.2.4.1 Requirements .................... 3-5

3.2.4.2 Compliance and Verification .............. 3-5

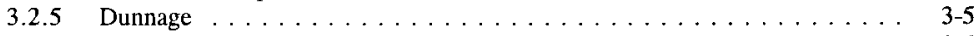

3.2.5.1 Requirements ..................... 3-5

3.2.5.2 Compliance and Verification $\ldots \ldots \ldots$ 3-6 


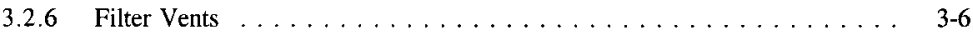

3.2.6.1 Requirements . . . . . . . . . . . . . . . . . . 3-6 3-6

3.2.6.2 Compliance and Verification $\ldots \ldots \ldots \ldots$ 3-6 . . . . . .

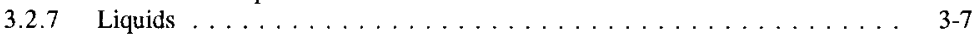

3.2 .7 .1 Requirements . . . . . . . . . . . . . . . . . 3-7

3.2.7.2 Compliance and Verification ............. 3-7

3.3 NUCLEAR PROPERTIES CRITERIA AND REQUIREMENTS--

CH TRU WASTE . . . . . . . . . . . . . . . . . . . . . 3-7

3.3.1 Nuclear Criticality (Pu-239 Fissile Gram Equivalent) . . . . . . . . . . 3-7

3.3.1.1 Requirements . . . . . . . . . . . . . . . . . 3-7

3.3.1.2 Compliance and Verification .............. 3-8

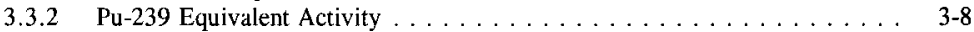

3.3.2.1 Requirements . . . . . . . . . . . . . . . . 3-8

3.3.2.2 Compliance and Verification .............. 3-8

3.3.3 Contact Dose Rate . . . . . . . . . . . . . . . . . . . . . . . 3-9

3.3.3.1 Requirements . . . . . . . . . . . . . . . . . . . 3-9

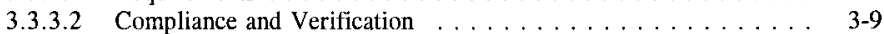

3.3 .4 Thermal Power . . . . . . . . . . . . . . . . . . . . . . . 3-9

3.3.4.1 Requirements . . . . . . . . . . . . . . . . . . . . . 3-9

3.3.4.2 Compliance and Verification ............... 3-10

3.3.5 TRU Alpha Activity Concentration . . . . . . . . . . . . . 3-10

3.3.5.1 Requirements . . . . . . . . . . . . . . . . . . . 3-10

3.3.5.2 Compliance and Verification .............. 3-10

3.4 CHEMICAL PROPERTIES CRITERIA AND REQUIREMENTS-

CH TRU WASTE . . . . . . . . . . . . . . . . . . . 3-11

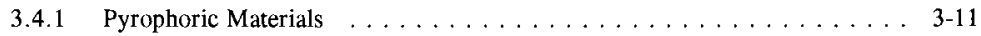

3.4.1.1 Requirements . . . . . . . . . . . . . . . . . . 3-11

3.4.1.2 Compliance and Verification .............. 3-11

3.4 .2 Mixed Wastes . . . . . . . . . . . . . . . . . . . 3-11

3.4.2.1 Requirements ....................... . . 3-11

3.4.2.2 Compliance and Verification ............... 3-12

3.4 .3 Chemical Compatibility . . . . . . . . . . . . . . . . 3-13

3.4.3.1 Requirements . . . . . . . . . . . . . . . . . . 3-13

3.4.3.2 Compliance and Verification ............... 3-13

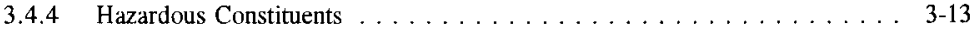

3.4.4.1 Requirements . . . . . . . . . . . . . . . . . 3-13

3.4.4.2 Compliance and Verification ................ 3-13

3.4.5 Explosives, Corrosives, and Compressed Gases . . . . . . . . . . . . 3-13

3.4.5.1 Requirements . . . . . . . . . . . . . . . . . . . 3-13

3.4.5.2 Compliance and Verification . . . . . . . . . . . . . 3-14

3.4.6 Polychlorinated Biphenyl Concentration . . . . . . . . . . . . . . 3-14

3.4.6.1 Requirements ... . . . . . . . . . . . . . . . . . 3-14

3.4.6.2 Compliance and Verification ... . . . . . . . . . 3-14

3.5 GAS GENERATION CRITERIA AND REQUIREMENTS- CH TRU WASTE . . . 3-14

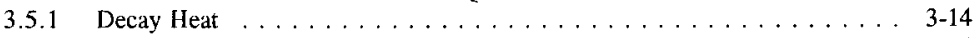

3.5.1.1 Requirements . . . . . . . . . . . . . . . . . . 3-14

3.5.1.2 Compliance and Verification ................... 3-15

3.5.2 Flammable Volatile Organic Compounds . . . . . . . . . . . . . 3-15

3.5.2.1 Requirements . . . . . . . . . . . . . . . . . . 3-15

3.5.2.2 Compliance and Verification ............ 3-15 


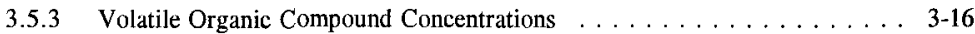

3.5.3.1 Requirements . . . . . . . . . . . . . . . . . . . 3-16

3.5.3.2 Compliance and Verification $\ldots \ldots \ldots \ldots \ldots$ 3-16

3.5 .4 Aspiration . . . . . . . . . . . . . . . . . . 3-17

3.5.4.1 Requirements . . . . . . . . . . . . . . . . 3-17

3.5.4.2 Compliance and Verification .............. 3-17

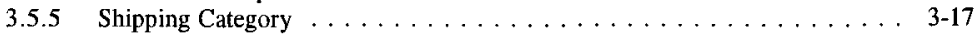

3.5.5.1 Requirements . . . . . . . . . . . . . . . . 3-17

3.5.5.2 Compliance and Verification ............. 3-17

3.5 .6 Confinement Layers . . . . . . . . . . . . . . . . . . 3-17

3.5.6.1 Requirements . . . . . . . . . . . . . . . . 3-17

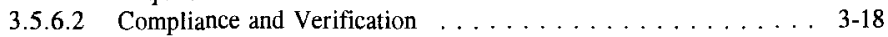

3.6 DATA PACKAGE CRITERIA AND REQUIREMENTS-CH TRU WASTE . . . . 3-18

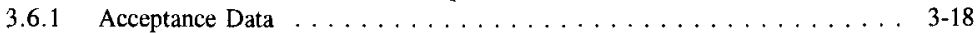

3.6.1.1 Requirements . . . . . . . . . . . . . . . . . . . 3-18

3.6.1.2 Compliance and Verification . . . . . . . . . . . . 3-19

3.6.2 RCRA Data . . . . . . . . . . . . . . . . . . . . 3-20

3.6.2.1 Requirements ..................... . 3-20

3.6.2.2 Compliance and Verification ............... 3-20

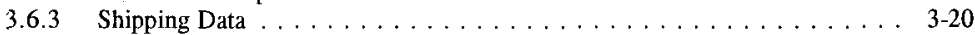

3.6.3.1 Requirements . . . . . . . . . . . . . . . . . . 3-20

3.6.3.2 Compliance and Verification .............. 3-20

4.0 HANFORD SITE COMPLIANCE PLAN FOR TRAMPAC $\ldots \ldots \ldots \ldots \ldots \ldots$. . . .

4.1 PAYLOAD CLASSIFICATION AND ASSIGNMENT OF SHIPPING

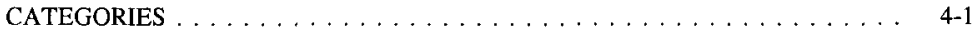

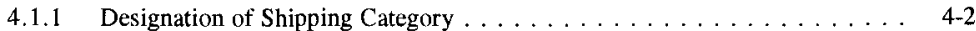

4.1.1.1 Requirements ...................... . 4-2

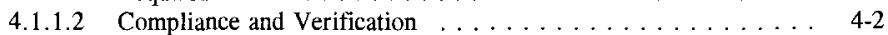

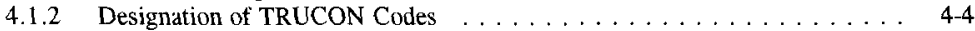

4.1.2.1 Requirements . . . . . . . . . . . . . . . . . 4-4

4.1.2.2 Compliance and Verification ... . . . . . . . . . . 4-4

4.2 PHYSICAL FORM OF THE WASTE $\ldots \ldots \ldots \ldots \ldots \ldots \ldots \ldots \ldots$

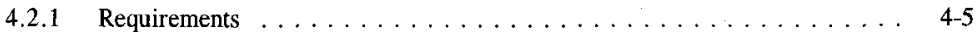

4.2 .2 Compliance and Verification ..................... $4-5$

4.3 CHEMICAL PROPERTIES OF THE WASTE . . . . . . . . . . . . . 4-6

4.3.1 Prohibited Waste Items . . . . . . . . . . . . . . . . . . . 4-6

4.3.1.1 Requirements . . . . . . . . . . . . . . . . . . . 4-6

4.3.1.2 Compliance and Verification $\ldots \ldots \ldots \ldots . \ldots \ldots$ 4-7

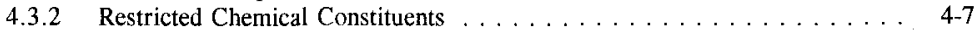

4.3.2.1 Requirements . . . . . . . . . . . . . . . 4 4-7

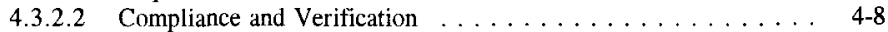

4.4 CHEMICAL COMPATIBILITY $\ldots \ldots \ldots \ldots \ldots \ldots \ldots \ldots \ldots \ldots$

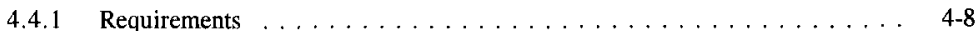

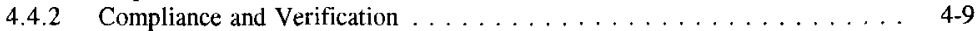

4.5 GAS DISTRIBUTION AND PRESSURE BUILDUP $\ldots \ldots \ldots \ldots \ldots \ldots \ldots$

4.5 .1 Requirements . . . . . . . . . . . . . . . . . . . . . . 4 4-9

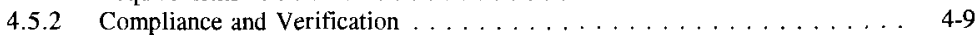


4.6 PAYLOAD CONTAINER AND CONTENTS CONFIGURATION . . . . . . . 4 4-10

4.6.1 Payload Container and Overpacking Configuration . . . . . . . . . . . 4-10

4.6.1.1 Requirements ..................... 4-10

4.6.1.2 Compliance and Verification ................ 4-10

4.6 .2 Payload Container Filters . . . . . . . . . . . . . . . . 4-11

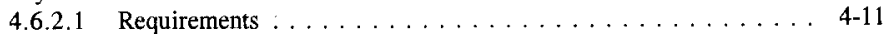

4.6.2.2 Compliance and Verification .............. 4-11

4.6 .3 Rigid Liners . . . . . . . . . . . . . . . . . . . . . $4-11$

4.6.3.1 Requirements ...................... . . . . . . . . . . . .

4.6.3.2 Compliance and Verification .............. . . 4-12

4.6 .4 Inner Confinement Layers . . . . . . . . . . . . . . . . . . 4-12

4.6.4.1 Requirements . . . . . . . . . . . . . . . . . . 4 4-12

4.6.4.2 Compliance and Verification ............... 4-12

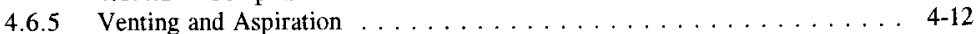

4.6.5.1 Requirements . . . . . . . . . . . . . . . . . . . 4-12 . . . . . . . . .

4.6.5.2 Compliance and Verification ............... . . . . . . . . . . .

4.7 ISOTOPIC INVENTORY AND FISSILE CONTENT $\ldots \ldots \ldots \ldots \ldots \ldots \ldots . . . .4 .4$

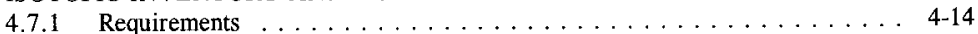

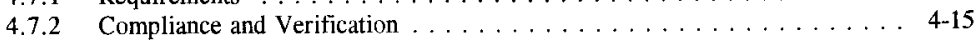

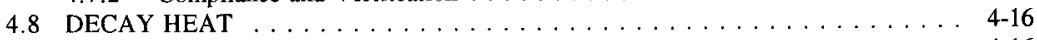

4.8.1 Requirements . . . . . . . . . . . . . . . . 4-16

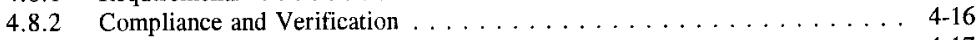

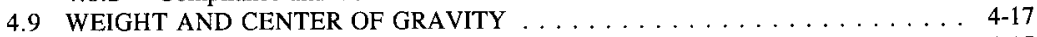

4.9 .1 Requirements ... . . . . . . . . . . . . . . . $4-17$

4.9 .2 Compliance and Verification $\ldots \ldots \ldots \ldots \ldots \ldots \ldots \ldots \ldots \ldots$ 4-18

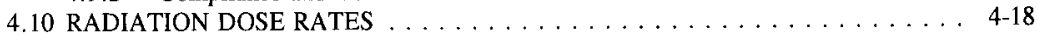

4.10 .1 Requirements ......................... 4-18

4.10 .2 Compliance and Verification . . . . . . . . . . . . . . . 4-19

4.11 PAYLOAD ASSEMBLY CRITERIA . . . . . . . . . . . . . . . . . . 4-19

4.11.1 Certification of Individual Payload Containers for Transport in the TRUPACT-II (Analytical Payload Shipping Category) . . . . . . . . . . . 4-20

4.11.1.1 Requirements . . . . . . . . . . . . . . . . . . . . 4 4-20

4.11 .1 .2 Compliance and Verification . . . . . . . . . . . . 4-20

4.11.2 Certification of Individual Payload Containers for Transport in the

TRUPACT-II (Test Payload Shipping Category) . . . . . . . . . . . . 4 4-22

4.11.2.1 Requirements . . . . . . . . . . . . . . . . . 4-22

4.11.2.2 Compliance and Verification .............. 4-22

4.11 .3 Assembly of a TRUPACT-II Payload . . . . . . . . . . . . 4-23

4.11.3.1 Requirements . . . . . . . . . . . . . . . . . 4-23

4.11.3.2 Compliance and Verification .............. 4-23

4.11 .4 Use of Dunnage Containers ... . . . . . . . . . . . . 4-24

4.11.4.1 Requirements . . . . . . . . . . . . . . . . 4 4-24

4.11 .4 .2 Compliance . . . . . . . . . . . . . . 4-24

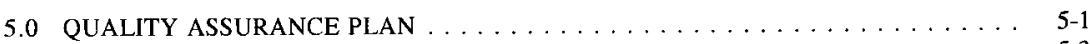

5.1 ORGANIZATION AND QA PROGRAM $\ldots \ldots \ldots \ldots \ldots \ldots \ldots \ldots$

5.2 PERSONNEL QUALIFICATION AND TRAINING $\ldots \ldots \ldots \ldots \ldots \ldots \ldots$

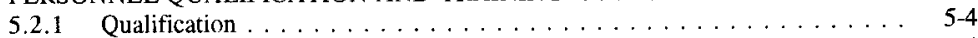

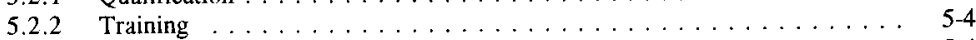

5.3 QUALITY IMPROVEMENT $\ldots \ldots \ldots \ldots \ldots \ldots \ldots \ldots \ldots \ldots$ 


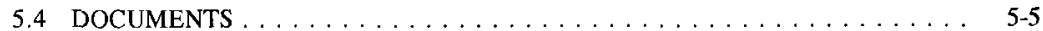

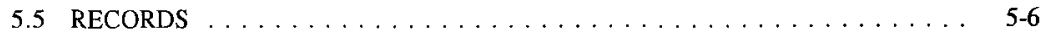

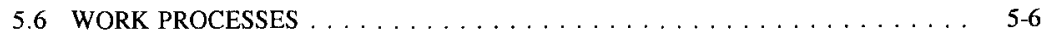

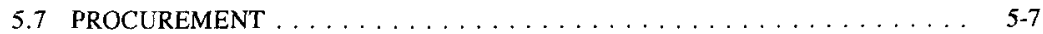

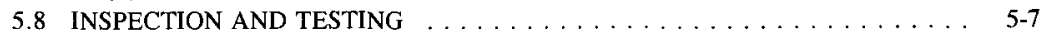

5.9 ASSESSMENT REQUIREMENTS $\ldots \ldots \ldots \ldots \ldots \ldots \ldots \ldots \ldots \ldots \ldots$

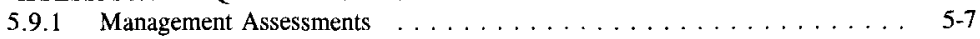

5.9 .2 Independent Assessments $\ldots \ldots \ldots \ldots \ldots \ldots \ldots \ldots \ldots$

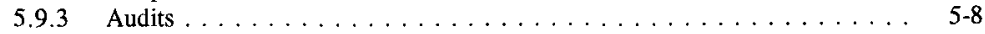

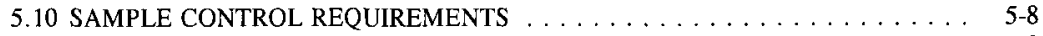

5.11 SCIENTIFIC INVESTIGATION REQUIREMENTS $\ldots \ldots \ldots \ldots \ldots \ldots \ldots$

5.12 SOFTWARE REQUIREMENTS $\ldots \ldots \ldots \ldots \ldots \ldots \ldots \ldots \ldots$

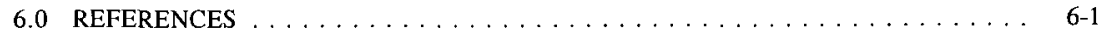

\section{APPENDICES}

A SUMMARY OF CH TRU WASTE ACCEPTANCE CRITERIA, REQUIREMENTS, AND COMPLIANCE AND VERIFICATION DOCUMENTS AND PROCEDURES $\ldots$ A-1

B CH TRU WASTE CERTIFICATION CHECKLIST $\ldots \ldots \ldots \ldots \ldots \ldots \ldots$

C PAYLOAD CONTAINER TRANSPORTATION CERTIFICATION DOCUMENT:

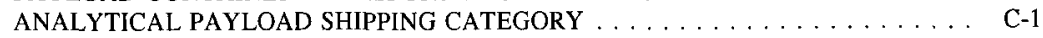

D PAYLOAD CONTAINER TRANSPORTATION CERTIFICATION DOCUMENT:

TEST PAYLOAD SHIPPING CATEGORY $\ldots \ldots \ldots \ldots \ldots \ldots \ldots \ldots \ldots$

E PAYLOAD ASSEMBLY TRANSPORTATION CERTIFICATION DOCUMENT . . . . E-1 
HNF-2600 Revision 0

\section{TABLES}

2-1 Review, Approval, and Control Requirements for the Hanford Site Certification Plan . . 2-15

3-1 Maximum Number of Containers per TRUPACT-II and Authorized Packaging

Configurations

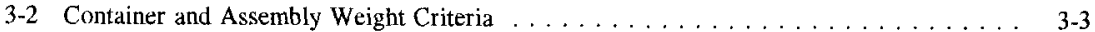

3-3 Nuclear Críticality Criteria . . . . . . . . . . . . . . . . . . . . . . 3-8

3-4 EPA Hazardous Waste Numbers Acceptable at WIPP $\ldots \ldots \ldots \ldots \ldots \ldots \ldots \ldots$. . . . . . . . .

3-5 VOC Concentration Limits for $\mathrm{CH}$ TRU Waste Payload Containers . . . . . . . . . . 3-16

4-1 TRU Waste Types and Corresponding Waste Material Types . . . . . . . . . . . 4-3

4-2 Approved Payload Container and Configuration Definitions $\ldots \ldots \ldots \ldots \ldots \ldots \ldots$. . . . . .

4-3 Approved Payload Configurations for TRUPACT-II Shipments . . . . . . . . . 4 4-13

5-1 Cross-Reference of Quality Assurance Requirements $\ldots \ldots \ldots \ldots \ldots \ldots$ 5-2 
HNF-2600 Revision 0

\section{FIGURES}

1-1 Hanford Site TRU Waste Certification Program Document Hierarchy . . . . . . . . . 1-2

2-1 Hanford Site TRU Waste Certification Program Functional Organizational Chart $\ldots . . \quad 2-2$

2-2 Certification Flow for Retrievably Stored TRU Waste $\ldots \ldots \ldots \ldots \ldots$. . . . . . . 


\section{ACRONYMS AND ABBREVIATIONS}

\begin{tabular}{|c|c|}
\hline $\begin{array}{l}\text { ASME } \\
\text { ASTM }\end{array}$ & $\begin{array}{l}\text { American Society of Mechanical Engineers } \\
\text { American Society for Testing and Materials }\end{array}$ \\
\hline $\mathrm{C}$ of $\mathrm{C}$ & Certificate of Compliance \\
\hline $\mathrm{CAO}$ & Carlsbad Area Office \\
\hline CAR & corrective action request \\
\hline Certification Plan & Hanford Site Transuranic Waste Certification Plan (Hanford 1998) \\
\hline CFR & Code of Federal Regulations \\
\hline $\mathrm{CH}$ & contact-handled \\
\hline CH TRU & contact-handled transuranic \\
\hline CIN & container identification number \\
\hline $\mathrm{CO}$ & certification official \\
\hline $\mathrm{CWC}$ & Central Waste Complex \\
\hline DMS & Data Management System \\
\hline DOD & U.S. Department of Defense \\
\hline DOE & U.S. Department of Energy \\
\hline DOE-RL & U.S. Department of Energy-Richland Operations Office \\
\hline DOT & U.S. Department of Transportation \\
\hline $\mathrm{dpm}$ & disintegration(s) per minute \\
\hline DQO & data quality objective \\
\hline EPA & U.S. Environmental Protection Agency \\
\hline FDH & Fluor Daniel Hanford \\
\hline FGE & fissile gram equivalent \\
\hline $\mathrm{FGE} / \mathrm{g}$ & mass values by $\mathrm{Pu}-239 \mathrm{FGE}$ conversion factors \\
\hline GC & gas chromatography \\
\hline GC/MS & gas chromatography/mass spectrometry \\
\hline GFAA & graphite furnace atomic absorption \\
\hline ICP & inductively coupled plasma \\
\hline $\mathrm{ICV}$ & inner containment vessel \\
\hline LDR & land disposal restriction \\
\hline $\mathrm{M} \& \mathrm{O}$ & management and operating \\
\hline $\mathrm{mrem} / \mathrm{hr}$ & milliroentgen(s) equivalent man per hour \\
\hline MS & mass spectrometry \\
\hline NIST & National Institute of Standards and Technology \\
\hline $\mathrm{nCi} / \mathrm{g}$ & nanocurie(s) per gram \\
\hline NCR & nonconformance report \\
\hline NDA & nondestructive assay \\
\hline NDE & nondestructive examination \\
\hline
\end{tabular}




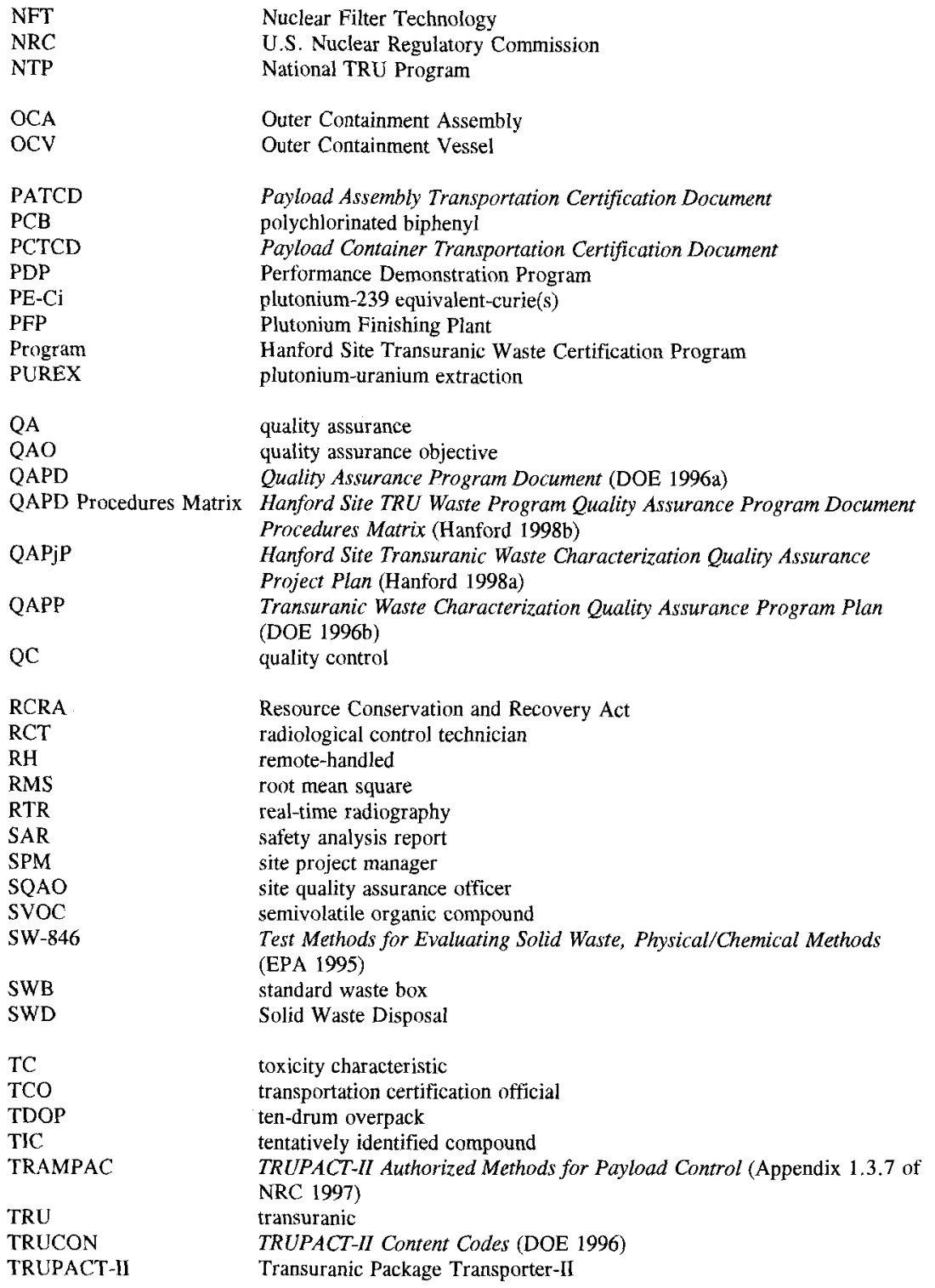


TRUPACT-II SARP TWBIR

VOC

WAC

WIPP

WIPP SAR

WIPP WAC

WRAP

WSPF

WWIS
Safety Analysis Report for the TRUPACT-II Shipping Package (NRC 1997) Transuranic Waste Baseline Inventory Report (DOE 1995b)

volatile organic compound

waste acceptance criteria

Waste Isolation Pilot Plant

Waste Isolation Pilot Plant Safety Analysis Report (Westinghouse 1995)

Waste Acceptance Criteria for the Waste Isolation Pilot Plant (DOE 1996d

Waste Receiving and Processing

Waste Stream Profile Form

Waste Isolation Pilot Plant Waste Information System 


\section{DEFINITIONS}

Acceptable Knowledge. An EPA term which includes process knowledge and results from previous testing, sampling, and analysis associated with the waste. Acceptable knowledge includes information regarding the raw materials used in a process or operation, process description, products produced, and associated wastes. Acceptable knowledge documentation includes the site history and mission, site-specific processes or operations, administrative building controls, and all previous and current activities that generate a specific waste.

Aluminum Honeycomb Spacer Assembly. An assembly which is located within each end of the ICV to provide:

1. A generous void volume to accommodate payload gas generation.

2. An energy-absorbing barrier between the payload and the ICV dished heads.

Assay. The observation of spontaneous or stimulated nuclear radiations, interpreted to estimate the content of one or more radionuclides in a material.

Assessment. Evaluation process used to measure the performance or effectiveness of a system and its elements. Assessment is an all-inclusive term used to denote any of the following: audit, performance evaluation, management systems review, peer review, inspection, or surveillance.

Audit. Planned and documented independent assessment to determine by investigation, examination, or evaluation of objective evidence, the adequacy of and compliance with established procedures, instructions, drawings, and other applicable documents, and the effectiveness of implementation. An audit should not be confused with surveillance or inspection activities performed for the sole purpose of process control or product acceptance.

Carbon Composite Filter. See "Filter Vent."

Certification Authority. Authorization to certify TRU waste to the WIPP Waste Acceptance Criteria which is granted by the CAO to those TRU waste generator/storage sites whose TRU Waste Programs have been evaluated and found to be acceptable.

Certified Waste. Payload containers, loaded with waste, that have been verified to meet the criteria of this document.

Chemical Compatibility. Assessing the properties of all potential chemicals in a payload container $(>1$ weight percent), there must be no adverse safety or health hazards produced as a result of any mixtures that could occur.

Combustible Materials. Organic materials that are dominantly cellulosic (e.g., cotton, paper, cloth, wood, etc.) but also includes plastics.

Compressed Gas. Compressed gases are those materials defined as such by 49 CFR 173, Subpart G.

Contact-Handled TRU Waste. Transuranic waste materials that are packaged in such a way that the dose rate at the surface of the waste package is not greater than $200 \mathrm{mrem} / \mathrm{hr}$. 
Content Code. A uniform system applied to waste forms to group those with similar characteristics for purposes of shipment in TRUPACT-II.

Corrosive Materials. Corrosive materials are those defined as such by 40 CFR 261.22 (a)(l).

Decay Heat. Heat produced by radioactive emissions that is absorbed in the surrounding material.

Defense TRU Waste. Nuclear waste derived from the manufacture of nuclear weapons and operation of naval reactors. Associated activities include (a) naval reactors development, (b) weapons activities, including defense inertial confinement fusion, (c) verification and control technology, (d) defense nuclear materials production, (e) defense nuclear waste materials and by-products management, (f) nuclear waste and materials security and investigations, and (g) research and development. See CAO Interim Guidance on Ensuring Waste Qualifies for Disposal at the Waste Isolation Pilot Plant (DOE 1997)

DOE Field Element. The first line DOE field element that carries the organizational responsibility for (1) managing and executing assigned programs, (2) directing contractors who conduct the programs, and (3) assuring that environment, safety, and health are integral parts of each program.

Explosive Materials. Explosive materials are those defined as such by 49 CFR 173 , Subpart C.

Filter Vent. A filter vent is defined as filter media manufactured of carbon composite, Kevlar, stainless steel, or any material that enables the filter to meet the minimum performance specifications stipulated in Appendix 1.3.5, "Specification for Filter Vents," of the TRUPACT-II SARP.

Fissile Gram Equivalent (FGE). An isotopic mass of radionuclide normalized to Pu-239.

Flammable Volatile Organic Compound (VOC). A headspace gas VOC that has a National Fire Protection Association Flammability Hazard Degree of 3 or 4 and a flash point of less than $100^{\circ} \mathrm{F}$ or considered, by EPA, to be a significant fire hazard under WIPP repository conditions. Flammable headspace gas VOCs that are evaluated for the TRU waste program are listed in Table 1-3 of the TRU Waste Characterization QAPP.

Free Liquid. Liquid that is not sorbed on or in a host material such that it could spill or drain from its container.

G Value. The number of molecules of gas species produced per 100 electron volts of decay energy absorbed by the waste.

Germanium Counter. An assay device with high purity germanium as the detection element.

Glovebox. A sealed box with windows and rubber gloves attached to parts such that an operator's hands and arms are protected as he works inside the box.

Headspace. That volume of any containment that is not occupied by the volume of waste material. "Headspace" is also used to refer to the gases contained in this volume.

Immobilized Materials. Materials that are fixed in a matrix such as glass, ceramic, cement, concrete, etc. 
Inner Containment Vessel. The assembly (comprised of a lid and body) providing a secondary level of containment for the payload. Within each end of the Inner Containment Vessel (ICV) is an aluminum honeycomb spacer assembly.

Item Description Code. A numerical code applied to individual waste forms (including source if applicable) to provide identification which is used for physical segregation and computerized record keeping and tracking.

Miscertification. A waste container that is certified for disposal based on radiography, but that visual examination determines cannot be certified as meeting the WIPP WAC requirements for prohibited items.

NaI Drum Counter. Assay performed on drums using sodium iodide crystals as the measurement device in the detector.

Newly Generated TRU Waste. Waste generated after the development, approval, and implementation of a TRU waste characterization program that meets the requirements outlined in the TRU Waste Characterization QAPP. Newly generated TRU waste also includes any previously generated waste (stored waste) that undergoes any form of treatment, processing, or repackaging in accordance with an approved quality assurance project plan.

Nondestructive Assay. Assay methods for waste items that do not affect the physical or chemical form of the material.

Nondestructive Examination. Methods which allow examination of items without affecting the chemical or physical forms of these items. An example is real-time radiography (RTR) which provides visible evidence of the contents of payload containers.

Oil-Dri. A trade name for a basically clay material absorbent.

Outer Containment Assembly. The assembly (comprised of a lid and body) providing a primary level of containment for the payload. The Outer Containment Assembly (OCA) completely surrounds the Inner Containment Vessel and consists of an exterior stainless steel shell, a relatively thick layer of polyurethane foam, and an inner stainless steel boundary which forms the Outer Containment Vessel (OCV).

Outer Containment Vessel. The innermost boundary of the Outer Containment Assembly.

Overpack. A payload container placed around another container to control contamination, or enclose a damaged container.

Package. The reusable Type B shipping container (i.e., TRUPACT-II or RH-TRU 72-B Cask) loaded with TRU waste payload containers, that has been prepared for shipment in accordance with the Packaging QA Program.

Packaging QA Program. A site-specific document which defines the quality assurance and quality control activities applicable to usage of the NRC-approved packaging. This program shall meet the requirements of 10 CFR Part 71, Subpart $\mathrm{H}$. 
Packaging. The reusable Type B shipping container for transport of TRU waste payload containers (i.e., TRUPACT-II or RH-TRU 72-B Cask). A transportation device consisting of an assembly of components necessary to ensure compliance with the requirements of Titles 49 C.FR Part 173, Subpart I and 10 CFR Part 71.4.

Passive-Active Neutron Counter. A device that measures the radiations that occur spontaneously or naturally (passive) and those that are induced by external irradiation (active) and comparing the results of both measurements.

Payload Container Assembly. An assembly of payload containers, such as a seven-pack of drums, that is intended to be handled and emplaced as a single unit.

Payload Container. The outermost container (e.g., 55-gal. drums, Standard Waste Boxes) for TRU waste material that is placed in a reusable Type B shipping container (i.e., TRUPACT-II or RH-TRU 72-B Cask) for transport.

Payload Pallet. A lightweight pallet with an aluminum honeycomb core, used for loading and unloading 14, 55-gallon drums of CH-TRU waste at one time.

Payload. Contact-Handled Transuranic (CH TRU) waste contained within 14, 55-gallon drums or two Standard Waste Boxes (SWBs). The payload is considered to include a lift pallet if Standard Waste Boxes are not used. Any dunnage used external to the 55-gallon drums or SWBs is also considered to be part of the payload.

Pipe Component. A stainless steel container used for packaging specific waste forms within a 55-gallon drum. The pipe component is exclusively used as part of the pipe overpack.

Pipe Overpack. A payload container consisting of a pipe component positioned by dunnage within a 55-gallon drum with a rigid, polyethylene liner and lid. Fourteen pipe overpacks will fit within the TRUPACT-II packaging.

Plutonium Equivalent Curie (PE-Ci). An equivalent radiotoxic hazard of a radionuclide normalized to Pu-239.

Polyethylene Liners. Rigid drum liners molded from high-density polyethylene, typically with a wall thickness of about 0.09 inches $(90$ mils). The liner generally has a snap-on cover of the same material.

Pressurized Vessels (Containers). Smaller containers in the payload container such as aerosol cans, which may hold compressed gas.

Pu-239 Fissile Gram Equivalent. The amount of $\mathrm{Pu}-239$ which would produce the equivalent $\mathrm{K}_{\mathrm{eff}}$ as that determined for the fissile material in the container (assuming all containers are in an optimally moderated in infinite array). U-235 and U-233 and other isotopes shall be calculated as Pu-239 fissile equivalents using ANSI/ANS-8.15-1981.

Pyrophoric. Materials which may ignite spontaneously or which emit sparks when scratched or struck especially with materials such as steel.

Radioassay (RA). Assay methods used to identify and quantify radionuclides in TRU waste. 
Radiochemical Assay. Assay performed with wet samples in a radiochemical laboratory using separation techniques.

Radiography. A nondestructive testing method that uses X-rays, gamma rays, or neutrons to inspect and determine the physical form of waste.

Remote-Handled Transuranic Waste. Packaged TRU waste whose external surface dose rate exceeds 200 mrem per hour. For the WIPP, there is an upper limit of 1000 rem per hour.

Residual Liquid. Liquids in quantities of less than 1 volume percent of the waste container that result from liquid residues remaining in well-drained internal containers, condensation of moisture, and liquid separation resulting from sludge/resin setting.

Retrievably Stored TRU Waste. Waste generated after 1970 and before the development, approval, and implementation of a TRU waste characterization program that meets the requirements outlined in the TRU Waste Characterization QAPP.

Segmented Gamma Scan. Assay device.

Shipper. A TRU Waste Generator/Storage Site that releases a TRUPACT-Il or RH-TRU 72-B Cask to a carrier for shipment.

Shipping Category. A grouping system for CH-TRU waste payload containers which assures incompatible groups are not mixed in the same TRUPACT-II.

Shipping Package. The Packaging with its radioactive contents, or Payload, as presented for transportation (10 CFR 71.4). The Package is denoted as the TRUPACT-II Contact-Handled Transuranic Waste Shipping Package, or equivalently, the TRUPACT-II Shipping Package, or TRUPACT-II Package.

Standard Waste Box (SWB). A payload container authorized for use with TRUPACT-II Transportation Packages that meets Department of Transportation (DOT) Specification 7A Type A. The Standard Waste Box was designed specifically to fit TRUPACT-II. Two Standard Waste Boxes (one on top of another) can fit within the TRUPACT-II Packaging.

Ten-Drum Overpack. A specialized payload container authorized for use within the TRUPACT-II packaging. One Standard Waste Box or ten 55-gallon drums can fit inside a Ten Drum Overpack (TDOP). One TDOP will fit within the TRUPACT-II packaging.

Tentatively Identified Compounds. Nontarget compounds identified using GC/MS. These reported concentrations will have a higher uncertainty associated with them than the reported target analyte concentrations.

Test Category. Decay Heat determination from testing of individual waste packages for hydrogen generation prior to placement in TRUPACT-II.

TRAMPAC. TRUPACT-II Authorized Methods for Payload Control document developed to show how the all waste parameters are controlled to assure TRUPACT-II payloads meet all of the TRUPACT-II shipping requirements and limits. 
Transportation Authority. Authorization for use of the TRUPACT-II or RH-TRU 72-B Cask for transportation of TRU waste, which is granted by the CAO to those TRU waste generator/storage sites whose TRU Waste Programs have been evaluated and found to be acceptable.

Transuranic (TRU) Wastes. Wastes contaminated with alpha-emitting radionuclides of atomic number greater than 92 (e.g., the radioactive isotopes of plutonium), have half-lives greater than 20 years, and are present in concentrations greater than 100 nanocuries per gram of waste.

TRU Mixed Waste. TRU waste that is co-contaminated with hazardous constituents as identified in 40 CFR Part 261, Subparts C and D.

TRU Waste Certification Plan. A site-specific document that describes the methods used by the Site to comply with each TRU waste acceptance criterion and requirement. This program document shall include procedural and administrative controls, and must describe all activities pertaining to TRU waste certitication including the required $\mathrm{QA}$ and $\mathrm{QC}$ activities applicable to the certification of TRU waste to the WAC.

TRUCON. TRUPACT-II Content Codes (DOE 1996) document developed to show wastes characterized and grouped together for controlling the payload in each TRUPACT-II.

TRUPACT-II. An NRC certified Type B transportation packaging used for transportation of contact-handled transuranic wastes.

TRUPACT-11 Packaging. The Packaging consisting of an Outer Containment Assembly, an Inner Containment Vessel and two aluminum honeycomb spacer assemblies.

TRUPACT-II User. Organizations or facilities that prepare a TRUPACT-II for release to a carrier for shipment. Users assure, via their TRUPACT-II User Program, that the payload, inspection, testing, closing, and release for shipment of the TRUPACT-II meets the requirements of the TRUPACT-II C of C. Users may also perform minor maintenance on the TRUPACT-II.

Twist and Tape. A method of bag closure for waste consisting of gathering the neck of the bag, twisting tightly, and wrapping tightly with plastic tape. Often called "horsetail."

Validation. An activity that demonstrates or confirms that a process, item, data set, or service satisfies the requirements defined by the user. Data validation requirements for the TRU waste program include signature release and are described in the TRU Waste Characterization QAPP.

Verification. The act of authenticating or formally asserting the truth that a process, item, data set, or service is, in fact, that which is claimed. Data verification is the process used to confirm that all review and validation procedures have been completed. Data verification requirements for the TRU waste program are described in TRU Waste Characterization QAPP.

Volatile Organic Compounds. For the purposes of the TRU waste program, those gas VOCs listed in the TRU Waste Characterization QAPP (Table 12-1 and the target VOCs listed in Table 13-1) and any additional compounds tentatively identified by the VOC analytical procedures used to satisfy QAPP requirements. 
Waste Acceptance Criteria. Criteria developed for the safe disposal of TRU waste in the Waste Isolation Pilot Plant, meeting the very long term disposal requirements of the WIPP underground salt bed.

Waste Certification. Formal and documented activities associated with waste processing and records required to certify that the waste has been characterized and meets WIPP Waste Acceptance Criteria.

Waste Characterization. The process of determining that TRU waste meets the requirements of the WAC by the acceptable performance of the activities defined by site-specific, CAO-approved plans outlined in Table 2-4 (e.g., quality assurance project plans, etc.).

Waste Form. The physical form of the waste such as sludges, combustibles, metals, etc.

Waste Material Type. Further divisions of waste types based on $\mathrm{G}$ (flammable) values (gas generation potential).

Waste Package Assembly. An assembly of waste packages, such as a seven-pack of drums, that is intended to be handled and emplaced in a single unit by the WIPP waste handling system.

Waste Packaging. The process of filling a payload container with waste and remaining within the controls applied to layers of confinement.

Waste Stream. Waste material generated from a single process or from an activity that is similar in material, physical form, and hazardous constituents.

Waste Type. Waste type refers to physical types of waste such as solidified inorganics, solid inorganics, solidified organics, and solid organics. 


\subsection{INTRODUCTION}

As a generator of transuranic (TRU) and TRU mixed waste destined for disposal at the Waste Isolation Pilot Plant (WIPP), the Hanford Site must ensure that its TRU waste meets the requirements of U.S. Department of Energy (DOE) Order 5820.2A, Radioactive Waste Management, and the Waste Acceptance Criteria for the Waste Isolation Pilot Plant (DOE 1996d) (WIPP WAC). The WIPP WAC establishes the specific physical, chemical, radiological, and packaging criteria for acceptance of defense TRU waste shipments at WIPP. The WIPP WAC also requires that participating DOE TRU waste generator/treatment/storage sites produce site-specific documents, including a certification plan, that describe their management of TRU waste and TRU waste shipments before transferring waste to WIPP. The Hanford Site must also ensure that its TRU waste destined for disposal at WIPP meets requirements for transport in the Transuranic Package Transporter-II (TRUPACT-II). The U.S. Nuclear Regulatory Commission (NRC) establishes the TRUPACT-II requirements in the Safety Analysis Report for the TRUPACT-II Shipping Package (NRC 1997) (TRUPACT-II SARP).

Figure 1-1 illustrates the hierarchy of regulatory requirements for TRU waste certification and reflects the flow-down of requirements from higher-level documents to site-level documents. To ensure that future changes to the WIPP WAC and other relevant requirements documents are appropriately reflected, this Hanford Site Transuranic Waste Certification Plan (hereinafter referred to as the Certification Plan) will be reviewed at least annually and updated as necessary.

This Certitication Plan establishes the programmatic framework and criteria within which the Hanford Site ensures that contact-handled $(\mathrm{CH})$ TRU wastes can be certified as compliant with the WIPP WAC and TRUPACT-II Authorized Methods for Pcyload Control (Appendix 1.3.7 of the TRUPACT-II SARP) (TRAMPAC). This Certitication Plan does not address remote-handled (RH) defense TRU forms. This Certification Plan includes the following sections:

- Section 2.0, "Certification Program Organization at the Hanford Site," identifies Hanford Site organizations involved in the TRU Waste Certification Program (the Program), describes the interaction between the characterization, certification, and transportation personnel, and lists the responsibilities of key Program officials.

- Section 3.0, "Hanford Site Compliance Plan for WIPP WAC," summarizes the WIPP WAC requirements and describes the Hanford Site's contact-handled transuranic (CH TRU) waste management program, including documents and activities that implement and verify compliance with each requirement.

- Section 4.0, "Hanford Site Compliance Plan for TRAMPAC," describes the Hantord Site's CH TRU waste management practices to demonstrate compliance with the TRUPACT-II SARP.

- Section 5.0, "Quality Assurance Plan," describes how the Hanford Site's Program complies with Quality Assurance Program Document (DOE 1996a) (QAPD), WIPP WAC, and 10 Code of Federal Regulations (CFR) Part 71, Subpart $H$ quality assurance (QA) requirements for certification. The Hanford Transuranic Waste Packaging Quality Assurance Plan (Hanford 1998d) describes activities related to the use, maintenance, and control of packages used to store and transport waste to WIPP in compliance with U.S. Department of Transportation (DOT) and NRC requirements. 


\section{HNF-2600 Revision 0}

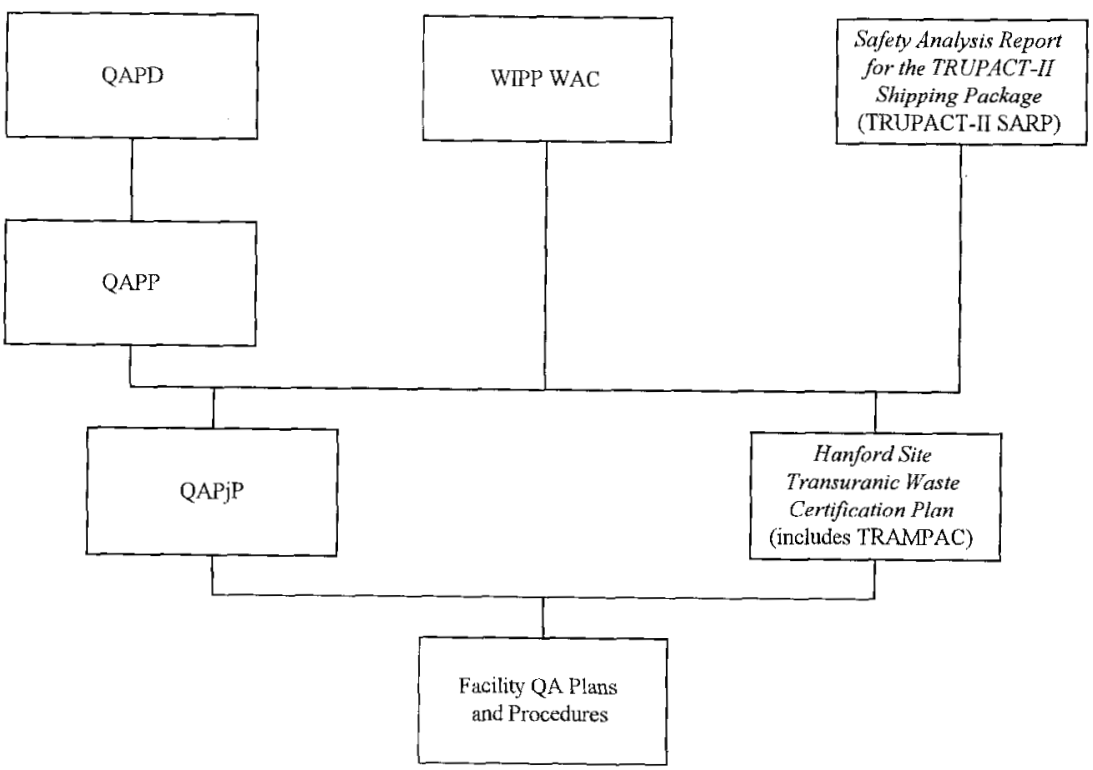

\footnotetext{
QA $\quad=$ quality assurance

QAPD $\quad$ = Quality Assurance Program Document (DOE 1996a)

QAPjP

QAPP

= Hanford Site Transuronir Waste Characterization Quality Asstrance Project Plan (Hanford 1998a)

TRAMPAC

$=$ Transuranic Waste Characterization Quality Assurance Program Plan (DOE 1996b)

WIPP WAC

$=$ TRUPACT-Il Authorized Methods for Payload Control (Appendix 1.3.7 of NRC 1997)

= Waste Acceptance Criteria for the Waste Isolation Pilot Plant (DOE 1996d)
}

Figure 1-I. Hanford Site TRU Waste Certification Program Document Hierarchy. 
This Certification Plan, which includes the Compliance Plan for TRAMPAC and associated QA Plan, together with the Hanford Site Transuranic Waste Characterization Quality Assurance Project Plan (Hanford 1998a) (QAPjP), establish the basis for the Hanford Site's waste characterization, certification, and transportation packaging operations. These documents are submitted to the Carlsbad Area Office (CAO) for review and approval. 
The responsibilities for TRU waste management at the Hanford Site are distributed within various organizations. This section identifies the Hanford Site organizations involved in the Program, describes the responsibilities of and interactions between these organizations, depicts a generalized process flow for TRU waste, summarizes the use of acceptable knowledge in the certification program, and describes the document control and records management process.

\subsection{ORGANIZATION AND RESPONSIBILITIES}

Figure 2-1 is a functional organization chart pertaining to TRU waste characterization, certification, and payload assembly activities at the Hanford Site. The following subsections identify the organizations that oversee the Program and describe the roles and responsibilities of key positions within the Program charged with implementing the requirements defined in this Certification Plan.

\subsubsection{NTP Team Leader}

The CAO manager delegates the responsibility for TRU waste management activities to the National TRU Program (NTP) team leader. The NTP team leader is responsible for overseeing TRU waste program activities at participating DOE sites, and ensuring NTP requirements are met. The NTP team leader, in conjunction with the CAO QA manager, is responsible for conducting audits of all activities associated with TRU waste characterization and certification described in the QAPP and QAPD. The NTP team leader reviews and approves this Certification Plan before its implementation. The CAO QA manager also reviews and approves this Certification Plan.

\subsubsection{DOE-Richland Waste Programs Division}

The DOE-RL Waste Programs Division is responsible for Program execution and oversight and serves as an interface between CAO and the Hanford Site. The DOE-RL TRU waste program manager ensures that Certification Plan activities comply with applicable DOE orders, the QAPP, the QAPjP, and all applicable federal and state regulations. The DOE-RL TRU waste program manager also ensures that resources and funding are available to accomplish TRU waste certification activities. DOE-RL TRU waste program manager reviews and approves this Certification Plan.

\subsubsection{FDH TRU Program Integration Manager}

The Fluor Daniel Hanford (FDH) TRU Program Integration Manager interfaces between the Waste Management Services project manager and DOE-RL Waste Programs Division and ensures that Program plans and operations are coordinated, integrated, and consistent with WIPP programs, policies, and guidance.

\subsubsection{Waste Management Services Project Manager}




\section{HNF-2600 Revision 0}

The Waste Management Services project manager interfaces between the TRU waste program site project manager (SPM) and DOE-RL on waste management projects. The Waste Management 


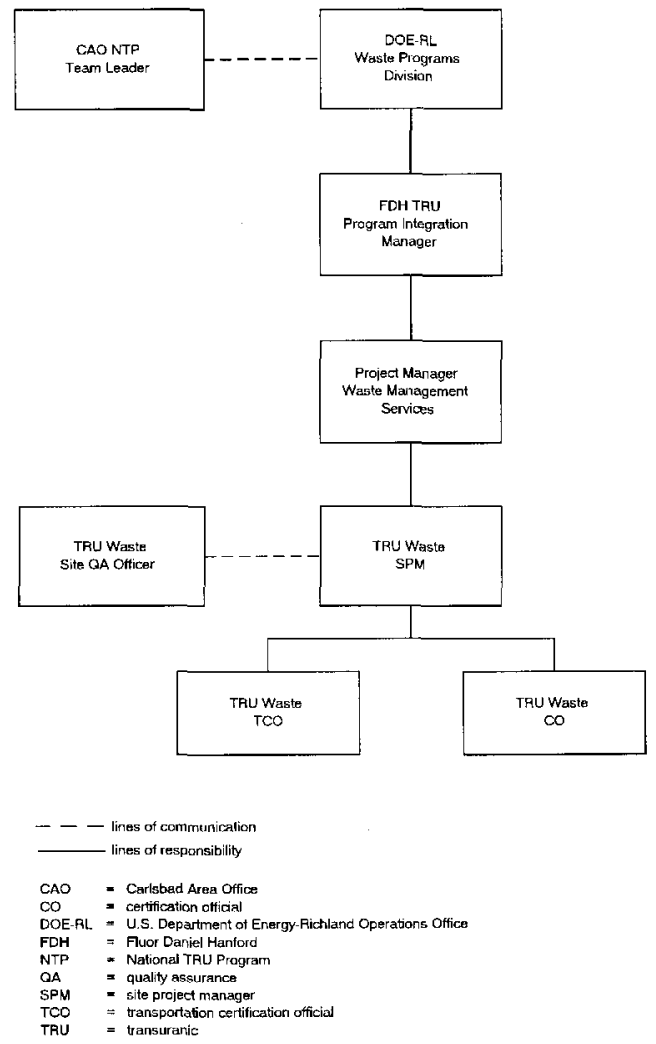

Figure 2-1. Eantord Site TRU Waste Certification Program Functional Organizational Chart. 
Services project manager ensures that Program plans and operations are coordinated, integrated, and consistent with WIPP programs, policies, and guidance; and is responsible for resolving with CAO any identified issues or concerns.

\subsubsection{Site Project Manager}

The SPM is the principal point of contact with DOE (including CAO, NTP, U.S. Department of Energy-Richland Operations Office [DOE-RL]) for technical activities associated with TRU waste. The SPM provides programmatic support for Hanford Site TRU waste organizations involved in TRU waste storage, characterization, certification, and transportation activities. The SPM coordinates with the Hanford Site waste certification official (CO) and transportation certification official (TCO) and oversees Program activities to ensure that Hanford Site TRU waste is characterized and certified compliant with WIPP requirements. Specific Program responsibilities assigned to the SPM include the following:

- Reviewing and approving the QAPjP and this Certification Plan

- Ensuring that the Hanford Site compliance plan for the TRAMPAC and associated documents are revised, reviewed, approved, and implemented as necessary to maintain authorization for shipping TRU waste to WIPP

- Ensuring Program personnel receive appropriate training and orientation

- Selecting, prioritizing, and tracking waste to be sampled and analyzed

- Validating and verifying project-level analytical data

- Reconciling analytical data with data quality objectives (DQOs)

- Certifying Waste Stream Profile Forms (WSPF) data

- Obtaining acceptable knowledge information from waste generators regarding U.S. Environmental Protection Agency (EPA) hazardous waste numbers

- Submitting quality assurance/quality control (QA/QC) reports to DOE field offices

- Transmitting testing, sampling, and analytical data to CAO

- Assisting the Hanford Site QA officer (SQAO) in defining and standardizing Program assessment criteria and preparing responses to deficiency reports, such as corrective action requests (CARs), generated by $\mathrm{CAO}$ or other external assessment organizations

- Halting certification activities if problems affecting the quality of certification processes or work products exist

- Notifying personnel of nonconformances

The SPM may delegate any of these activities to another individual; however, the SPM retains responsibility for ensuring that Program requirements are met. 


\subsubsection{Hanford Site Waste Certification Official}

The Hanford Site waste CO certifies all data and information necessary to document that all TRU waste payload containers prepared for shipment to WIPP meet all specified criteria. The CO coordinates certification-related activities and works closely with the SQAO to effect QC of the Program. Specific duties and responsibilities of the $\mathrm{CO}$ include the following:

- Certifying that waste is characterized in accordance with the requirements stipulated in the Hanford Site TRAMPAC and QAPjP

- Certifying that waste packages and waste shipments meet WIPP WAC requirements

- Interfacing with the SPM, TCO, and SQAO on matters related to certification

- Implementing the following Program QA activities:

- reviewing and approving this Certification Plan

- ensuring that copies of certification documents are managed as QA records in the designated repository

- preparing nonconformance reports (NCRs) and documenting corrective actions

- coordinating with the SQAO to analyze trends in program nonconformances for certification-related activities

- assisting the SQAO in preparing responses to deficiency reports, such as CARs, generated by $\mathrm{CAO}$ or other external assessment organizations

- Stopping certification activities if problems affecting the quality of certification processes or work products exist

The CO may designate one or more individuals to perform these responsibilities, but retains ultimate responsibility for ensuring that Program requirements are met.

\subsubsection{Hanford Site Quality Assurance Officer}

The SQAO provides QA oversight and planning for TRU waste characterization and certification, and oversees the implementation of the QAPjP and the QA requirements of the Certification Plan. The SQAO's general responsibilities include the following:

- Reviewing and approving this Certification Plan

- Coordinating internal and external audits and assessnents to verify compliance

- Tracking and evaluating trends in compliance with QA objectives (QAOs) established in the QAPjP by performing the following:

- ensuring that testing, sampling, and analytical facilities are assessed 
- ensuring that NCRs that affect program activities are prepared, when appropriate

- tracking and trending nonconformances

- verifying corrective actions have been taken to resolve nonconformances

- validating and verifying data at the project level

- submitting QA/QC reports to the SPM, as needed

- preparing and submitting semiannual QA summary reports to the SPM and FDH TRU Program Integration Manager

- Coordinating responses to deficiency reports (e.g., CARs) generated by CAO or other external assessment organizations

- Providing QA oversight for data package assembly and interface with the WIPP Waste Information System (WWIS)

- Stopping certification activities if problems affecting the quality of certification processes or work products exist

The SQAO may designate one or more individuals to perform the above functional responsibilities, but retains ultimate responsibility for assuring compliance with Program requirements.

\subsubsection{Hanford Site Transportation Certification Official}

The Hanford Site TCO ensures that the site-specific TRU waste packaging and transportation program complies with the TRAMPAC and applicable U.S. Department of Transportation (DOT) requirements specified in $49 \mathrm{CFR}$ and NRC requirements in $10 \mathrm{CFR} 71$. The TCO verifies payload containers and payload assemblies and ensures compliance with all packaging and records requirements. The TCO obtains WIPP authority to ship and ensures that all parameters identified in the TRAMPAC are met before the transportation packaging is released to a carrier for transport. Specific TCO responsibilities include the following:

- Ensuring that the Hanford Site compliance plan for TRAMPAC and associated documents are revised, reviewed, approved, and implemented, as necessary, for the Hanford Site to maintain authorization for off-site shipments of TRU waste

- Interfacing with the originating facility to develop and maintain procedures to load the TRUPACT-II in accordance with the TRUPACT-II SARP and WIPP WAC to ensure that all payloads meet all applicable requirements

- Maintaining Hanford Site TRUPACT-II Content Codes (TRUCON) in accordance with the TRUCON (DOE 1996) and requesting revisions from CAO, as necessary

- Providing information to the SPM to obtain WIPP approval to ship 
- Interfacing with the SPM, CO, and SQAO on matters related to payload certification and off-site transportation of TRU waste

- Developing and maintaining the packaging QA plan as required by the WIPP WAC

- Reviewing and approving this Certification Plan

- Reviewing all payload data sheets and documenting compliance with all packaging and shipping requirements described in this Certification Plan

- Preparing and signing Bills of Lading, Uniform Hazardous Waste Manifests, and Land Disposal Restriction (LDR) Notifications, as appropriate

Shipping activities related to the TRUPACT-II and WIPP acceptance include the following:

- Ensuring compliance with applicable DOT and NRC regulations

- Providing guidance to waste generators to assist their efforts to comply with the TRAMPAC and WIPP WAC criteria and requirements in implementing procedures affecting characterization, quality assurance, and waste certification

- Ensuring that the proper shipping category, TRUCON codes, and Hanford Site waste form number are assigned to each container and shipment

- Reviewing all payload data sheets and Hanford Site records to guarantee and document compliance with all packaging and shipping requirements

- In conjunction with the $\mathrm{CO}$, ensuring that all waste containers and shipments are certifiable for transport and that all documentation packages are complete and accurate

- Interfacing with the WWIS and the SPM to obtain approval to ship

The TCO may designate one or more individuals to perform these responsibilities, but retains ultimate responsibility for ensuring that certification-related Program requirements are met.

\subsection{CERTIFICATION PROCESS}

The Hanford Site TRU waste certification process involves interfaces between various organizations. With the exception of debris waste that is repackaged, the Hanford Site will manage all TRU waste as retrievably stored. The process for certifying waste and preparing it for transport to WIPP involves a series of operations. Initially, acceptable knowledge is used to assign EPA hazardous waste numbers, matrix parameter categories, waste material parameters, and radionuclide composition to individual waste containers. The Hanford Site Transuranic Waste Sampling Plan (Hanford 1998c) describes the rationale for delineating waste streams based on acceptable knowledge. Acceptable knowledge information for each waste stream is verified through testing, sampling, and analytical methods summarized below:

- Radiography and visual examination identify and confirm the matrix parameter category and waste material parameter weights. 
- Radioassay data identify and quantify radionuclide composition and concentration.

- Headspace gas sampling and analysis provide data to determine potential flammability, and confirm EPA hazardous waste numbers.

- Sampling and analysis of homogeneous solids and soil/gravel provide data to confirm listed and toxicity characteristic EPA hazardous waste numbers and quantify hazardous constituent concentration.

Figure 2-2 illustrates the certification process flow for retrievably stored TRU waste. Sections 3.0 and 4.0 detail the compliance and verification of each process operation and implementing procedure(s).

\subsubsection{Waste Stream Documentation}

Hanford Site waste generators produce waste stream documentation to meet Hanford Site waste acceptance criteria and support the waste stream approval process. Waste stream information is supplied on site-specific forms and attachments. At a minimum, generators provide the following waste stream information:

- Generator information

- Waste stream name

- Waste generating process description

- Radiological information (e.g., classification, reportable radionuclides, characterization method)

- Chemical constituent information (e.g., chemicals present, concentration ranges, characterization methods)

- LDR information, including identification of underlying hazardous constituents, if applicable

- Waste type information (e.g., physical state, inert materials, and stabilizing agents and/or absorbents used)

- Packaging information (e.g., container type and size, maximum weight)

- Additional attachments, including process flow information, analytical data, container drawings, or other waste acceptance information

In addition to waste stream information, generators submit the following waste container documentation:

- Container identification number

- Waste profile number

- Waste description 
HNF-2600 Revision 0

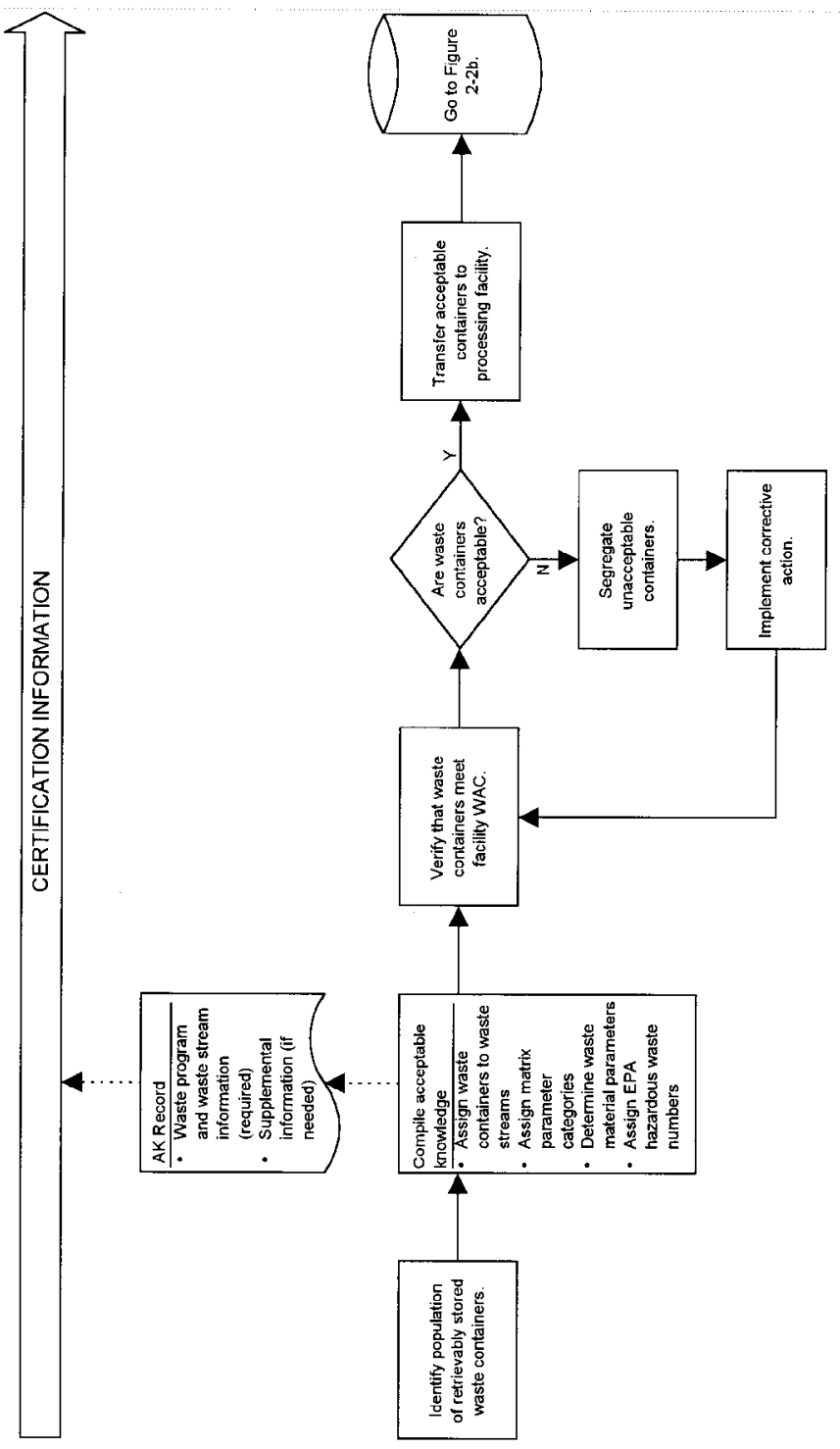

落 
HNF-2600 Revision 0

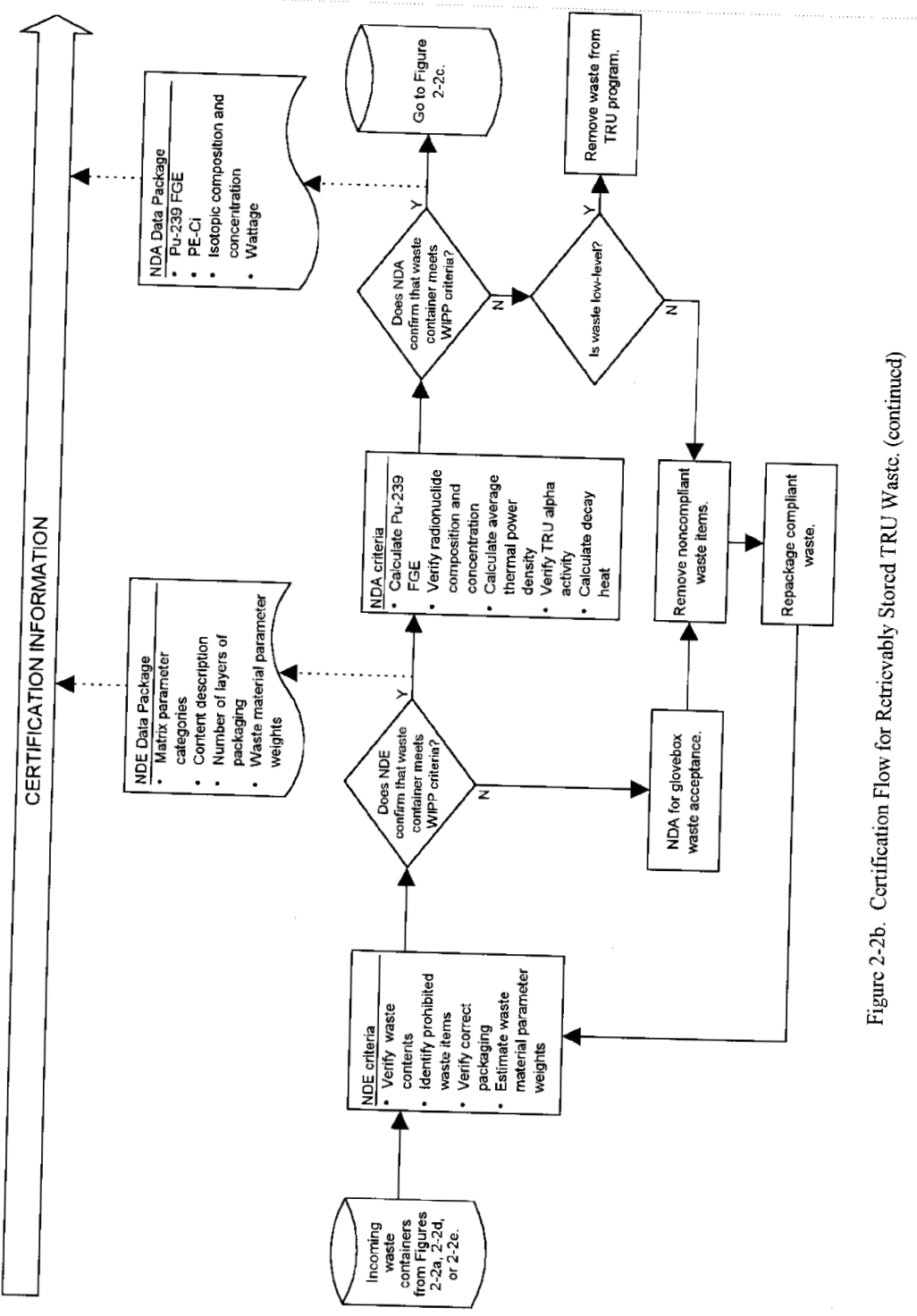


HNF-2600 Revision 0

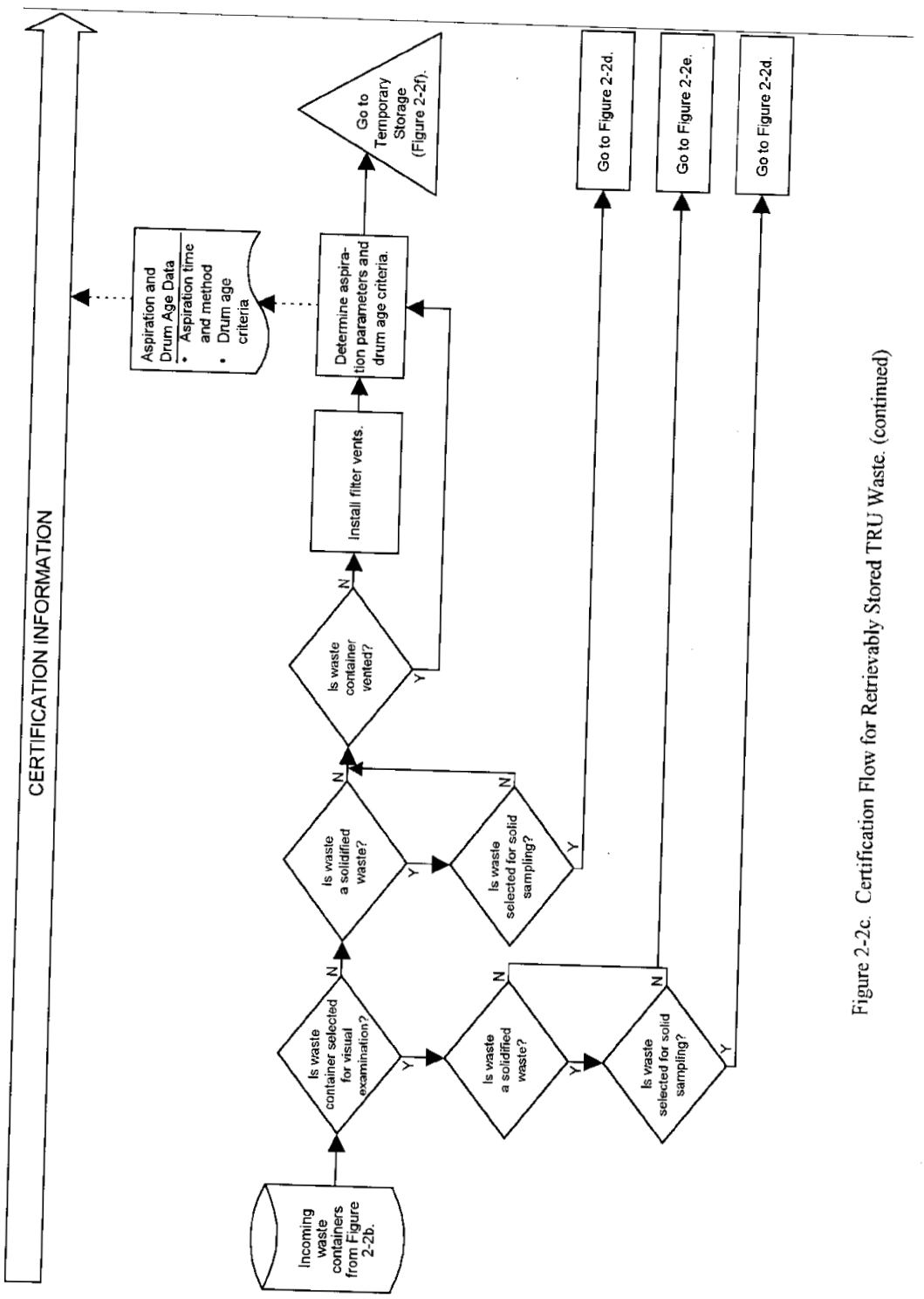




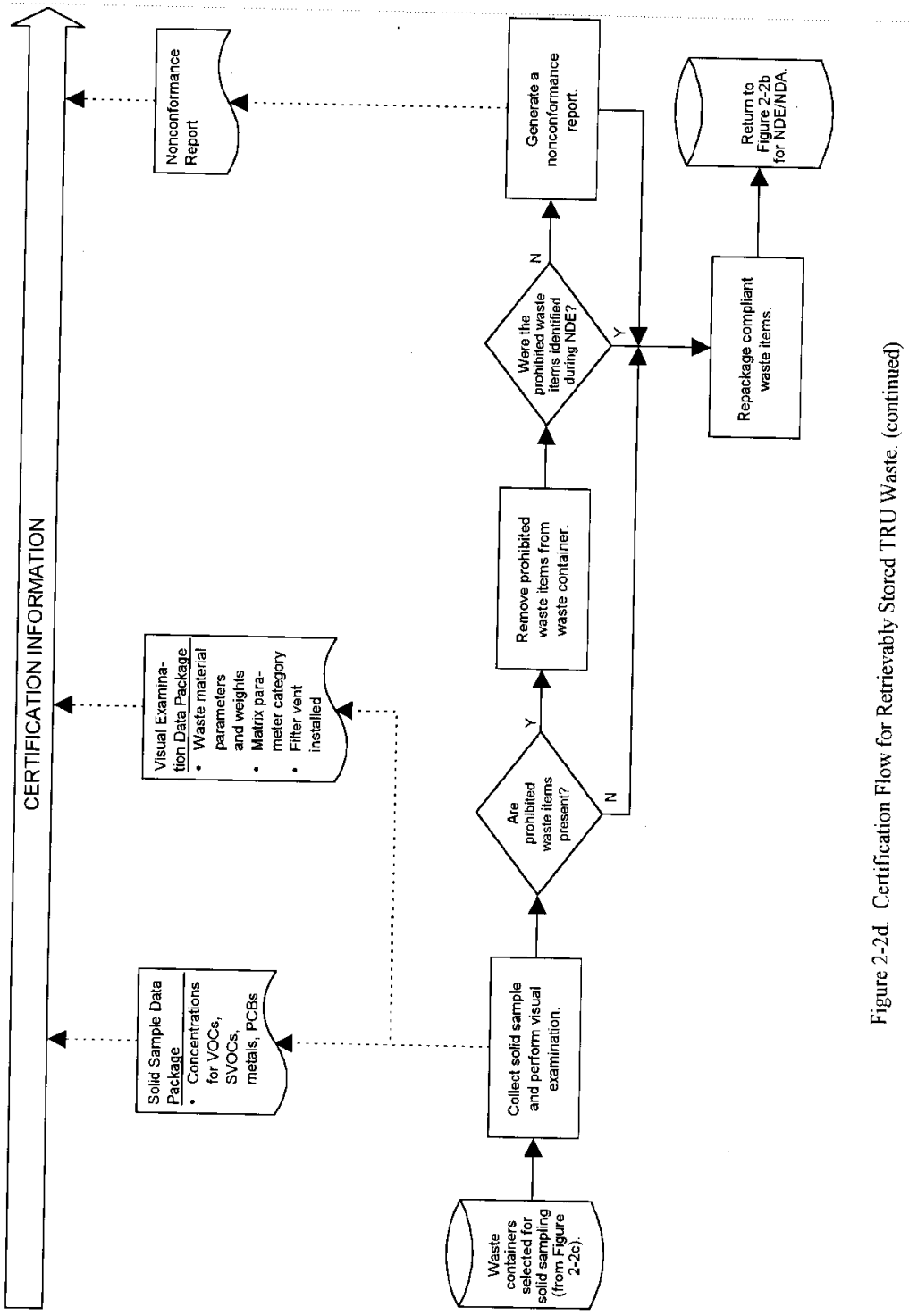


HNF-2600 Revision 0

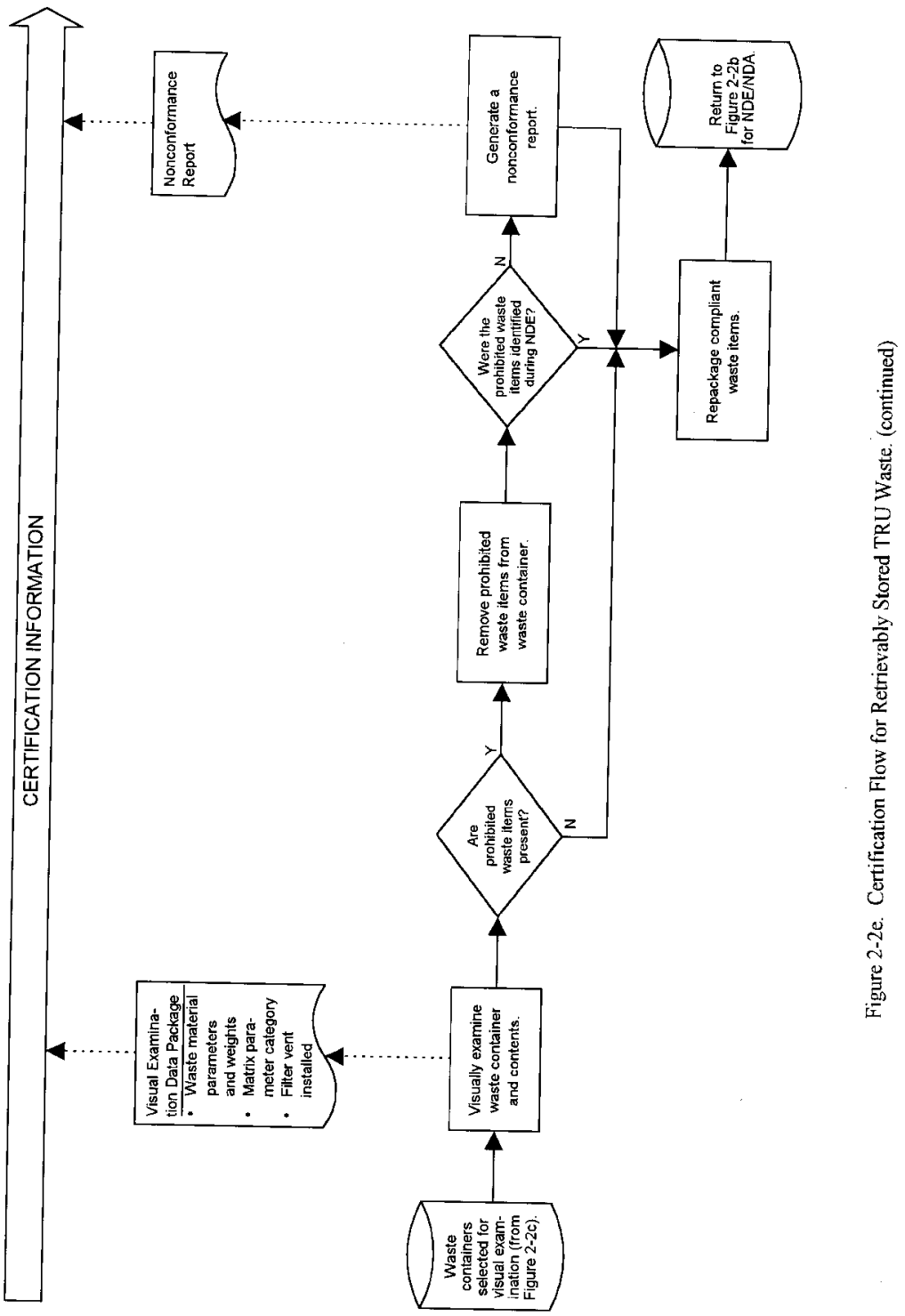


HNF-2600 Revision 0

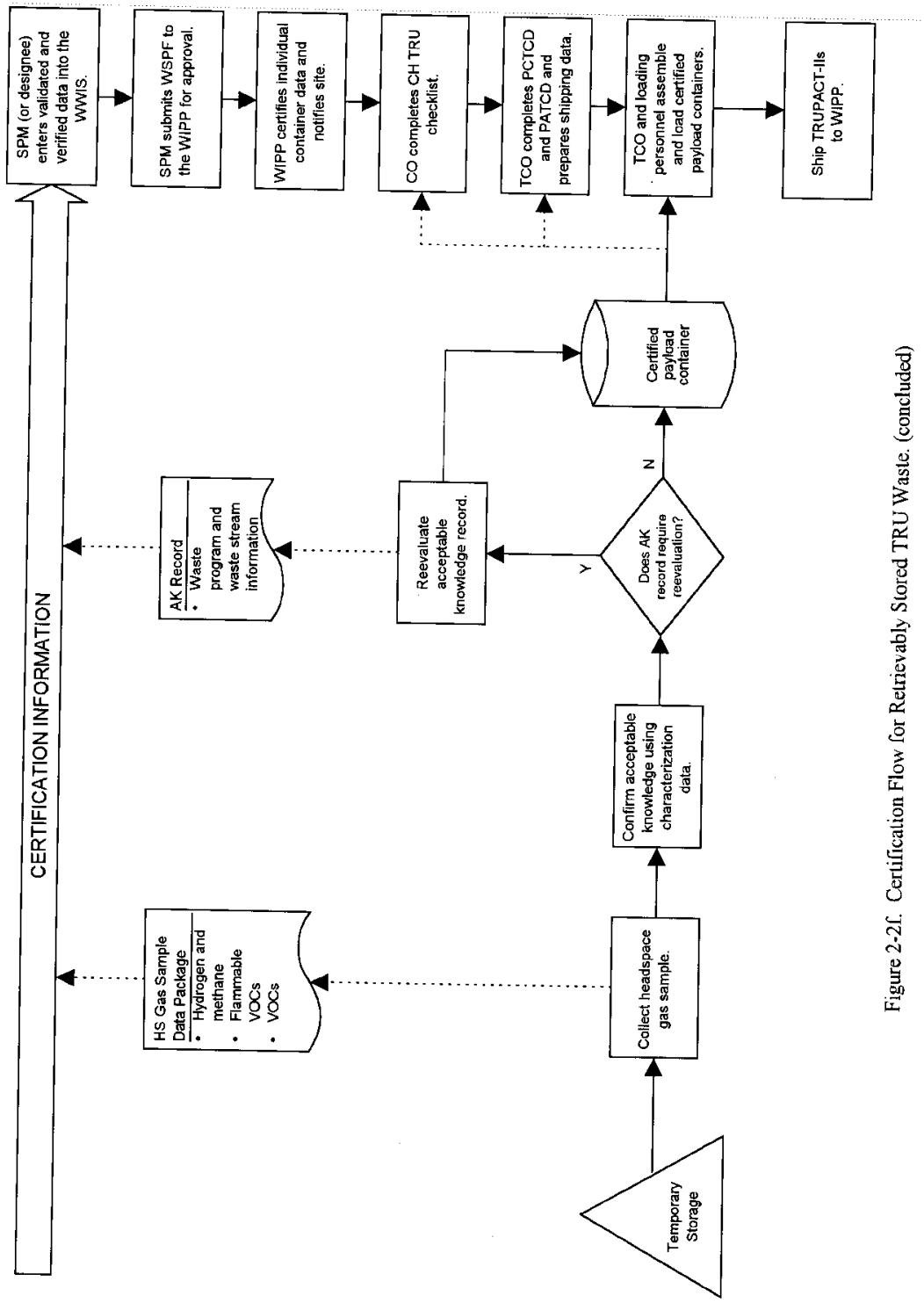


- Generator information

- Waste contents inventory

- EPA hazardous waste numbers

- Waste classifications or designations (i.e., Washington State hazardous waste codes)

- Dose rate information

- Reportable radionuclides and quantities

- Waste composition

- Packaging materials and quantities

Information provided by waste generators is supplemented with information gathered during TRU Program characterization and certification activities to meet data requirements for completing the WIPP Waste Stream Profile Form (WSPF) and WWIS submittals.

\subsubsection{Acceptable Knowledge Documentation}

The Hanford Site uses acceptable knowledge to assign matrix parameter categories and EPA hazardous waste numbers and to determine the waste material parameters and radionuclides present in waste streams. For each TRU waste stream, acceptable knowledge information is compiled in an auditable record; confirmed through radiography, visual examination, radiological assay, headspace gas sampling and analysis, and solidified waste sampling and analysis; and audited periodically to ensure adequacy of the information.

Information compiled to document acceptable knowledge on a site-wide and facility-specific basis includes TRU waste management program information, waste stream information, and supplemental documentation (including reference lists). Acceptable knowledge information sources are prioritized in terms of accuracy, with published documents and controlled databases being the most reliable. Unpublished data, internal procedures, and notes are considered to be the next most reliable, with correspondence and interviews considered the least defensible. Acceptable Knowledge Documentation Management (WMH-400, Section 7.1.9) describes the process for assembling and reviewing acceptable knowledge in compliance with the QAPP requirements and confirming acceptable knowledge information using results of testing, sampling, and analysis. This procedure also establishes administrative controls to ensure that responsibility, oversight, training, nonconformance, and corrective action activities are documented and comply with QAPP requirements. Performance is tracked by assessing the frequency of inconsistencies among different sources of information and by documenting results of acceptable knowledge confirmatory testing.

The SPM (or designee) reviews waste stream documentation and data packages resulting from radiography, visual examination, headspace gas sampling and analysis, and solidified waste sampling and analysis (as appropriate) to confirm matrix parameter category, EPA hazardous waste numbers, and waste material parameter designations using acceptable knowledge. Changes to EPA hazardous waste numbers are identified and justified based on confirmatory testing data. Acceptable knowledge information is reevaluated if discrepancies are identified between acceptable knowledge documentation and data from confirmatory testing.

\subsubsection{Waste Characterization and Certification Data Reporting}

The SPM (or designee) reconciles TRU waste characterization data with applicable data quality objectives (DQOs) and completes a WIPP WSPF for each Hanford Site TRU waste stream to 
be disposed at the WIPP. Summaries of waste stream information and reconciliation of DQOS comprise WSPF attachments. Transuranic Waste Characterization Data Quality Objectives Reconciliation and Reporting (WMH-400, Section 7.1.1) specifies the information required to complete the WSPF and describes the process for reconciling waste characterization data with Program-required parameters, preparing data summary reports, and correlating container identification to data packages.

The SPM transmits waste characterization, certification, and shipment data to WIPP using the WWIS. WIPP Waste Information System Data Entry and Reporting (WMH-400, Section 7.1.5) describes the process for entering and reporting required data on payload containers and assemblies into the WWIS.

\subsection{CERTIFICATION PROGRAM DOCUMENT CONTROL AND RECORDS MANAGEMENT}

This Certification Plan, which includes the Compliance Plan for TRAMPAC and associated QA pians, together with the Hanford Site QAPjP, establish the basis for the Hanford Site's TRU waste characterization, certification, and transportation packaging operations. These documents are submitted to $\mathrm{CAO}$ for review and approval. The individuals identified in Table 2-1 review and/or approve this Certification Plan and any revisions. The CO (or designee) reviews this Certification Plan at least annually and schedules revisions, reviews, approvals, and distribution.

Table 2-1. Review, Approval, and Control Requirements for the Hanford Site Certification Plan.

\begin{tabular}{lcccc}
\hline Organization/Reviewer & Review & $\begin{array}{c}\text { Review and } \\
\text { approval }\end{array}$ & $\begin{array}{c}\text { Change } \\
\text { approval }\end{array}$ & $\begin{array}{c}\text { Change } \\
\text { control }\end{array}$ \\
\hline National TRU Program Team Leader & - & $\mathrm{X}$ & $\mathrm{X}^{\mathrm{a}}$ & - \\
Carlsbad Area Office Quality Assurance Manager & - & $\mathrm{X}$ & $\mathrm{X}$ & - \\
DOE-RL TRU Waste Program Manager & - & $\mathrm{X}$ & $\mathrm{X}^{\mathrm{a}}$ & - \\
FDH TRU Program Integration Manager & $\mathrm{X}$ & - & - & - \\
Site Project Manager & - & $\mathrm{X}$ & $\mathrm{X}$ & $\mathrm{X}^{\mathrm{b}}$ \\
Site Quality Assurance Officer & - & $\mathrm{X}$ & $\mathrm{X}$ & - \\
Waste Certification Official & - & $\mathrm{X}$ & $\mathrm{X}$ & - \\
Transportation Certification Official & - & $\mathrm{X}$ & $\mathrm{X}$ & - \\
Note: - not required. & & & & \\
${ }^{2}$ Changes affecting performance criteria or data quality only. & & & \\
${ }^{\circ}$ Ensures compliance with records management requirements. & & &
\end{tabular}


Program personnel develop, maintain, and control this Certification Plan in accordance with TRU Document Control (WMH-400, Section 1.4.1). Program personnel generate records of characterization, certification, packaging, and transportation activities and review these records to ensure compliance with Program requirements. Approved records are collected, processed, stored, and maintained in accordance with records management requirements established in TRU Records Management (WMH-400, Section 1.5.1). 
HNF-2600 Revision 0

COMPLIANCE PLAN FOR WIPP WAC

This section describes the Hanford Site's methods of compliance and verification to meet WIPP WAC requirements for $\mathrm{CH}$ TRU waste, including transportation requirements (i.e., acceptable methods for payload compliance) defined in the TRAMPAC, and environmental compliance requirements for TRU mixed waste established in the WIPP RCRA Part B Permit Application (DOE 1996d) and the 40 CFR 191/194 Compliance Certification Application (DOE 1995a).

\subsection{REQUIREMENT ORGANIZATION}

WIPP WAC requirements are organized into five major categories: 1) container and physical properties, 2) nuclear properties, 3) chemical properties, 4) gas generation, and 5) data package. Sections 3.2 through 3.6 correlate with the organization in the WIPP WAC for CH TRU waste requirements. Waste shipped to WIPP must comply with the most restrictive of the CH TRU requirements established in the WIPP WAC and TRAMPAC; therefore, only the most restrictive requirements are described in this section. Revisions of requirements in referenced documents controlled by agencies or organizations other than DOE (e.g., EPA, New Mexico Environment Department, NRC) shall have precedence over values quoted in this Certification Plan. Changes incorporated in future revisions of the WIPP WAC will be reflected in future revisions of this Certification Plan.

Appendix A summarizes the WIPP WAC and TRAMPAC requirements and identifies the Hanford Site documents and procedures that implement each requirement. The numbering of WIPP WAC requirements in Appendix A correlates with the numbering system in the following subsections.

If a requirement is not met, Program personnel will segregate the nonconforming item and initiate an NCR or report the nonconformance in accordance with TRU Nonconforming Item Reporting and Control (WMH-400, Section 1.3.2). Corrective action will be taken in accordance with TRU Corrective Action Management (WMH-400, Section 1.3.1) to resolve nonconformances. See also Section 5.3 of this Certification Plan.

\subsection{CONTAINER AND PHYSICAL PROPERTIES CRITERIA AND REQUIREMENTS- CH TRU WASTE}

\subsubsection{Container Description}

\subsubsection{Requirements}

CH TRU waste shall only be shipped in 55-gal. drums, pipe overpacks in 55-gal. drums, standard waste boxes (SWBs), and ten-drum overpacks (TDOPs) in the TRUPACT-II. Containers shall meet the requirements of the TRUPACT-II SARP, Appendix 1.3.3, and Section 8.0 of the TRAMPAC. Drums shall be DOT specification $17 \mathrm{C}$ or $17 \mathrm{H}$, or UN1A2 reusable drums. SWBs, and TDOPs shall be manufactured in accordance with drawings supplied by the CAO. All payload containers shall be inspected to ensure they are in good condition and can withstand further handling prior to shipment. Table 3-1 provides the maximum number of containers per TRUPACT-II and the authorized packaging configurations. 
Table 3-1. Maximum Number of Containers per TRUPACT-II and Authorized Packaging Configurations.

\begin{tabular}{ll}
\hline Maximum Number of Containers & \multicolumn{1}{c}{ Authorized Packaging } \\
\hline 14 & 55-gal. drum \\
14 & Pipe overpacks in 55-gal. drums \\
2 & SWBs \\
2 & SWBs, each containing one bin \\
1 & SWBs, each containing four 55-gal. drums \\
1 & TDOP, containing ten 55-gal. drums \\
1 & TDOP, containing one SWB \\
1 & TDOP, containing one bin within an SWB \\
& TDOP, containing four 55-gal. drums within an SWB \\
\hline
\end{tabular}

Source: Table 3.2.1.2, WIPP WAC (Revision 5, Change Notice No. 2).

\subsubsection{Compliance and Verification}

The Hanford Site follows TRU Control of Purchased Items and Services (WMH-400, Section 2.3.3) to procure payload containers (i.e., 55-gal. drums, SWBs, and TDOPs) that meet the following requirements:

- SWBs and TDOPs are procured to the same standards and specifications as the containers used in Type A testing

- New 55-gal. drums are procured as UN1A2 reusable drums, in accordance with applicable requirements of 49 CFR Part 173 which is allowable per CAO memo CAO:NTP:JFS971144UFC5822. Fifty-five-gal. drums may also be procured to the same standards and specifications as the drums used in Type A testing.

Recovered drums are inspected to ensure that they are DOT Specification $17 \mathrm{C}$ or $17 \mathrm{H}$ or meet UN1A2 requirements for reusable drums. Permanent markings embossed on the bottom of the drums are used to verify the drum type if procurement records are not available. Program personnel examine retrievably stored containers for compliance with the applicable requirements and verify that the containers are in good condition in accordance with Transuranic Waste Sample and Waste Container Management Activities (WMH-400, Section 7.1.7). Program personnel document their procurement acceptance and/or visual inspections. If packages cannot be shown to meet the above requirements by procurement records and/or physical examination, Program personnel take corrective action (e.g., repackage the waste into a certifiable container) to resolve the nonconformance. The TCO verifies that the packaging meets applicable requirements and that the TRUPACT-II is assembled in an authorized packaging configuration, in accordance with Receive and Load TRUPACT Containers (WRP1-OP-0521) and Transuranic Waste Transportation and Disposal Certification (WMH-400, Section 7.1.8). 


\subsubsection{Container/Assembly Weight and Center of Gravity}

\subsubsection{Requirements}

Individual payload container weights shall be limited to the maximum weight used in the DOT Type A testing or the weight limits specified by TRUPACT-II restrictions, whichever is less.

Table 3-2 defines the weight limits that apply to CH TRU waste payload containers, loaded TRUPACT-IIs, and TRUPACT-II shipments. Because all weight criteria must be met, different payload configurations are restricted by different requirements. For example, a payload assembly of 14 55-gal. drums may not be greater than $7,265 \mathrm{lbs}$, even though the maximum weight of a single 55 gal. drum may be $1,000 \mathrm{lbs}$. Although the maximum weight of the payload assembly must not exceed $7,265 \mathrm{lbs}$, the weight available for the $\mathrm{CH}$ TRU waste payload assembly will be less, depending on

Table 3-2. Container and Assembly Weight Criteria.

Component Maximum Gross Weight (lbs)

Individual Payload Container-Required for Certification

55-gal. steel drum (DOT Spec. 17C and 17H)

55-gal. steel drum (UN/1 A2/X320/S)

55-gal. steel drum (UN/1 A2/X325/S)

55-gal. steel drum (UN/1A2/X400/S)

55-gal. steel drum (UN/1 A2/X425/S)

55-gal. steel drum (UN/1A2/X430/S)

$\leq 1,000$

$\leq 700$

$\leq 716$

55-gal. steel drum (UN/1A2/X435/S)

55-gal. drum overpacked in SWB

$\leq 882$

$\leq 937$

$\leq 948$

SWB

$\leq 959$

TDOP

$\leq 1,450$

$\leq 4,000$

$\leq 6,450^{\mathrm{a}}$

Pipe Overpack Payload Container-Required for Certification

Pipe Overpack 6-in. diameter

$\leq 328$

Pipe Overpack 12-in. diameter

$\leq 547$

Payload Container Assembly-After Waste is Certified

Payload Container Assembly

$\leq 7,265$

TRUPACT-II

$\leq 19,250$

Truck (Tractor/Trailer)

$\leq 80,000$

a Although the WIPP WAC maximum weight is higher for the TDOP (i.e.g, $\leq 6,700 \mathrm{lbs}$ ), the more restrictive weight requirement from the TRAMPAC is listed here.

Source: Table 3.2.2.2, WIPP WAC (Revision 5, Change Notice No. 2) and TRAMPAC, Section 11. 
the as-built weight of the TRUPACT-II to be used (the average as-built weight of a production TRUPACT-II is $12,705 \mathrm{lbs}$ ). The weight available for the CH TRU waste payload assembly is obtained by subtracting the as-built weight of a TRUPACT-II from the maximum gross weight of $19,250 \mathrm{lbs}$. The maximum gross weight per TRUPACT-II is specified based on an approximate asbuilt weight of $13,050 \mathrm{lbs}$ and an average payload weight of $6,200 \mathrm{lbs}$; this is usually the limiting weight for two TRUPACT-Iis per shipment. The DOT limit of $80,000 \mathrm{lbs}$ gross vehicle weight rating must also be met; this is the limiting weight for three TRUPACT-IIs per shipment.

The center of gravity of a loaded TRUPACT-II shall be determined by the weights and locations of the individual CH TRU waste payload containers. The total weight of the top seven-pack of drums or an SWB shall be less than or equal to the total weight of the lower seven-pack of drums or an SWB. The total weight of the top five drums in a TDOP shall be less than or equal to the total weight of the bottom five drums.

\subsubsection{Compliance and Verification}

Loading facility personnel weigh the individual payload containers, ensuring that individual payload container weights do not exceed maximum weight limits listed on Table 3-2 or weight limits for which the drum has been certified, whichever is less. After individual payload containers are certified, loading personnel ensure that the payload assembly does not exceed maximum weights listed in Table 3-2. The TCO verifies compliance with weight requirements and enters information on the Payload Container Transportation Certification Document (PCTCD). (For more information about the PCTCD, see Section 4.11 and Appendices C and D.) Loading facility personnel ensure that the center of gravity of a loaded TRUPACT-II meets the requirements by loading the heaviest seven-pack, an SWB, or TDOP on the bottom of the payload assembly. The TCO verifies that loading requirements are met. Loading facility personnel follow Receive and Load TRUPACT Containers (WRP1-OP0521), and the CO verifies container weight in accordance with Transuranic Waste Transportation and Disposal Certification (WMH-400, Section 7.1.8).

\subsubsection{Removable Surface Contamination (Payload Containers)}

\subsubsection{Requirements}

The degree of removable surface contamination for each CH TRU waste payload container or payload container assembly must be measured and documented prior to shipment. Removable surface contamination on CH TRU waste payload containers or container assemblies shall not be greater than 20 disintegrations per minute $(\mathrm{dpm})$ per $100 \mathrm{~cm}^{2}$ for alpha-emitting radionuclides and 200 dpm per $100 \mathrm{~cm}^{2}$ for beta-gamma-emitting radionuclides. Beta-gamma contamination may be less than or equal to $1,000 \mathrm{dpm}$ per $100 \mathrm{~cm}^{2}$ if it meets the requirements of $10 \mathrm{CFR} 835$ (DOE Radiological Control Manual, Table 2-2). Fixing surface contamination to meet the above criterion is not permitted.

\subsubsection{Compliance and Verification}

A Hanford Site radiological control technician (RCT) surveys TRU waste containers and container assemblies for removable surface contamination before the containers are loaded for shipment. The RCT assesses removable contamination and documents the results in accordance with Release Survey (WRP1-OP-1209) and Radioactive Material Shipment and Receipt Surveys (WRP1-OP-1201) and using equipment calibrated with National Institute of Standards and Technology 
(NIST) traceable sources. If the RCT determines that removable contamination exceeds 20 dpm per $100 \mathrm{~cm}^{2}$ for alpha-emitting radionuclides or $200 \mathrm{dpm}$ per $100 \mathrm{~cm}^{2}$ for beta-gamma-emitting radionuclides, the TCO determines whether surface contamination can be removed to meet established limits or requests that noncompliant container(s) and/or container assemblies be removed from the loading process and arranges for other certifiable container(s) to replace the noncompliant container(s). The CO confirms removable surface contamination survey results in accordance with Transuranic Waste Transportation and Disposal Certification (WMH-400, Section 7.1.8).

\subsubsection{Container Marking}

\subsubsection{Requirements}

Each CH TRU waste payload container shall be uniquely identified by means of labels permanently attached in conspicuous locations. The labels shall contain a unique container identification number consisting of site and container information. The container identification number shall be in medium- to low-density Code 39 bar code symbology (per MLL-STD-1189B) in characters at least 1 in. high, and alphanumeric characters at least 0.5 -in. high. The bar code identification labels shall be placed at three locations about 120 degrees apart so that at least one label is clearly visible when drums are assembled into a seven-pack (i.e., a label must be visible after slip sheets and wrapping are applied). Labels are required on the flat sides of SWBs. Each CH TRU waste payload container shall be marked with the shipping category after verification of all payload parameters. See Section 3.2.5 for dunnage container labeling requirements.

\subsubsection{Compliance and Verification}

All waste containers currently in the CWC have a bar code label containing a unique identification number. Generators procure waste containers with bar code labels affixed in accordance with the Hantord Site's container management program.

After verifying all payload parameters, Program personnel mark each container with the appropriate shipping category description as described in Section 4.1.1. The TCO verifies compliance with container marking requirements by visually inspecting all TRU waste containers and their labels and comparing them to the container data package prior to shipment in accordance with Receive and Load TRUPACT Containers (WRP1-OP-0521). The TCO confirms the appropriate shipping category and documents compliance on the CH TRU Waste Certification Statement (see Appendix B) and the PCTCD. The CO confirms container marking, in accordance with Transuranic Waste Transportation and Disposal Certification (WMH-400, Section 7.1.8).

\subsubsection{Dunnage}

\subsubsection{Requirements}

If too few payload containers meeting all payload container and transportation requirements are available, dunnage must complete one of the configurations specified in Table 3-1. An empty 55-gal. metal drum or empty SWB may be used as dunnage, as specified in Section 13.4 of the TRAMPAC. If an empty drum is used as dunnage to complete a seven-pack in a shipment to WIPP, the drum shall be labeled "EMPTY" or "DUNNAGE" and have a container marking per Section 3.2.4 of this Certification Plan, as appropriate. Dunnage containers shall have open vent ports (i.e., 
vent ports shall be unplugged or filtered). The empty drum shall be reported by container identification number (CIN) in the data package. Actual data (e.g., zeros, weights) shall be reported in the WWIS data fields for a dunnage drum that is part of a payload assembly. If a seven-pack of empty drums or an SWB is shipped as dunnage to fill a TRUPACT-Il, label the drums or SWB "EMPTY" or "DUNNAGE," but do not label them with container identification numbers or include them in WWIS data.

\subsubsection{Compliance and Verification}

In accordance with Receive and Load TRUPACT Containers (WRP1-OP-0521), loading facility personnel load the TRUPACT-II in one of the configurations identified in Table 3-1. If dunnage containers are used to complete a seven-pack assembly, loading personnel mark each dunnage container with a unique identification number, label the containers "EMPTY" or "DUNNAGE," and document this action. Dunnage drums in a seven-pack assembly are reported by CIN and reported in the WWIS. If a seven-pack of empty drums is shipped as dunnage, each dunnage container is labeled "EMPTY" or "DUNNAGE," but the containers are not marked with an identification number and not reported in the WWIS. Loading personnel open or vent dunnage containers to prevent container lids from popping off when a vacuum is drawn on the TRUPACT-II. The TCO verifies whether dunnage containers are used, whether the containers are marked and labeled as required, and documents the information on the PCTCD. The CO confirms the use of dunnage containers in accordance with Transuranic Waste Transportation and Disposal Certification (WMH-400, Section 7.1.8).

\subsubsection{Filter Vents}

\subsubsection{Requirements}

All payload containers (including overpacks, but not dunnage containers) shall be vented with filters to control gas concentration and pressure. Filters shall meet the specifications described in Appendix 1.3 .5 of the TRUPACT-II SARP.

\subsubsection{Compliance and Verification}

The Hanford Site procures Nuclear Filter Technology (NTF)-012, NFT-013, and NFT-020 (or equivalent) carbon composite filters for use on TRU waste containers. Filters meet the specifications described in the TRAMPAC and are procured in accordance with the Hanford Site's procurement process identified in Section 5.7. Program personnel ensure that all waste containers, including any overpacks, are vented with one or more of these filter(s). Program personnel verify filter vent installation by visual inspection, and document the installation inspection in accordance with Receive and Load TRUPACT Containers (WRP1-OP-0521). The CO confirms payload container venting in accordance with Transuranic Waste Transportation and Disposal Certification (WMH-400, Section 7.1.8). 


\subsubsection{Liquids}

\subsubsection{Requirements}

Sites shall have policies and procedures that prohibit free liquids being placed in newly generated $\mathrm{CH}$ TRU wastes. Sites shall ensure that $\mathrm{CH}$ TRU waste contains as little residual liquid as is reasonably achievable by pouring, pumping, or aspirating. Internal containers (e.g., bottles, cans) shall contain less than $1 \mathrm{in}$. $(2.5 \mathrm{~cm})$ of liquid in the bottom of the container. In no case shall the total liquid volume (i.e., the sum of all internal or payload container volumes) exceed:

- $2 \mathrm{~L}$ in a 55-gal. drum

- $8 \mathrm{~L}$ in an SWB

The total volume of residual liquid shall be less than one volume percent of the payload container.

\subsubsection{Compliance and Verification}

Generators ensure that TRU waste is not in free-liquid form, that minor residual liquids remaining in well-drained containers do not exceed one volume percent, and that the total liquid in the waste package does not exceed one volume percent.

For purposes of demonstrating compliance with this requirement, newly generated and retrievably stored waste will be managed identically. Initially, acceptable knowledge is used to determine container contents. Acceptable knowledge is confirmed by nondestructive examination (NDE) and/or visual examination. Program personnel estimate liquid volume by NDE and/or visual examination, in accordance with Transuranic Waste Repackaging, Visual Examination, and Sampling (WMH-400, Section 7.1.3) and applicable procedures listed in Appendix A and record the location of any liquid detected in a $\mathrm{CH}$ TRU waste container. NDE and/or visual examination personnel reject payload containers found to have greater than one volume percent liquid or greater than $1 \mathrm{in}$. of liquid in the bottom of an internal container and segregate them. If necessary, repackaging personnel repackage nonconforming waste containers in accordance with Transuranic Waste Repackaging, Visual Examination, and Sampling (WMH-400, Section 7.1.3). The CO confirms the liquids criteria in accordance with Transuranic Waste Transportation and Disposal Certification (WMH-400, Section 7.1.8).

\subsection{NUCLEAR PROPERTIES CRITERIA AND REQUIREMENTS-CH TRU WASTE}

\subsubsection{Nuclear Criticality (Pu-239 Fissile Gram Equivalent)}

\subsubsection{Requirements}

The fissile or fissionable radionuclide content, in terms of $\mathrm{Pu}-239$ fissile gram equivalent (FGE), of CH TRU waste payload containers shall be no greater than $200 \mathrm{~g}$ per 55-gal. drum, or 325 g per SWB or TDOP. The Pu-239 FGE shall be calculated using the methods detailed in Section 9.4 of the TRAMPAC. Table 3-3 defines the maximum allowable quantity of fissile material, expressed as Pu-239 FGE, for CH TRU waste in the TRUPACT-II. The maximum allowable quantity includes two times the measurement error, as specified in Section 9.4 of the TRAMPAC. 
Table 3-3. Nuclear Criticality Criteria.

\begin{tabular}{lc}
\hline Payload Container & Pu-239 FGE \\
\hline 55-gal. drum & $\leq 200$ \\
SWB & $\leq 325$ \\
TDOP & $\leq 325$ \\
Pipe component overpacked in 55-gal. drum & $\leq 200$ \\
TRUPACT-II & $\leq 325$ \\
TRUPACT-II (14 pipe overpacks) & $\leq 2800$ \\
\hline
\end{tabular}

Source: Table 3.3.1.2, WIPP WAC (Revision 5, Change Notice No. 2).

\subsubsection{Compliance and Verification}

Nondestructive array (NDA) personnel obtain the CH TRU waste fissile content in accordance with one or more of the radioassay procedures listed in Appendix A. All radioassay equipment is qualified under the corresponding Performance Demonstration Program (PDP) requirements. NDA personnel calculate the fissile or fissionable radionuclide content of the CH TRU waste container as Pu-239 FGEs according to approved calculation methods described in Section 9.4 of the TRAMPAC.

NDA personnel manually compute FGE and isotopic values or use computational algorithms to calculate values. NDA personnel validate and verify calculation programs in accordance with $T R U$ Software Quality Assurance (WMH-400, Section 6.1.1) before the software is used as part of the Program. Section 4.7.2 of this Certification Plan discusses FGE compliance and verification procedures for individual payload containers and TRUPACT-II payload assemblies. The CO confirms nuclear criticality criteria in accordance with Transuranic Waste Transportation and Disposal Certification (WMH-400, Section 7.1.8).

\subsubsection{Pu-239 Equivalent Activity}

\subsubsection{Requirements}

Untreated CH TRU waste shall not exceed $80 \mathrm{Pu}-239$ equivalent-curies (PE-Ci) of activity per 55-gal. drum, or $130 \mathrm{PE}$-Ci of activity per SWB. Untreated CH TRU waste in 55-gal, drums may contain up to 1800 PE-Ci of activity if overpacked in SWBs or TDOPs. Solidified/vitrified CH TRU waste shall not exceed $1800 \mathrm{PE}-\mathrm{Ci}$ of activity per 55-gal. drum. Appendix A of the WIPP WAC details the methods used to calculate PE-Ci.

\subsubsection{Compliance and Verification}

NDA personnel verify radionuclide composition and concentration using QAPP-approved methods as described in the QAPjP. NDA personnel calculate the activity of the CH TRU waste container as PE-Ci according to the methodology in Appendix A of the WIPP WAC. NDA personnel 
validate and verify the computational algorithms in the software in accordance with TRU Software Quality Assurance (WMH-400, Section 6.1.1) before the software is used as part of the Program. Program personnel identify payload containers exceeding $80 \mathrm{PE}-\mathrm{Ci}$ in a drum, $130 \mathrm{PE}-\mathrm{Ci}$ in an SWB, or $1800 \mathrm{PE}-\mathrm{Ci}$ for a 55 -gal. drum that is overpacked or that contains solidified/vitrified waste, segregate them, and disposition them in accordance with approved procedures listed in Appendix A. The CO confirms Pu-239 equivalent activity in accordance with Transuranic Waste Transportation and Disposal Certification (WMH-400, Section 7.1.8).

\subsubsection{Contact Dose Rate}

\subsubsection{Requirements}

CH TRU waste payload containers shall have a maximum contact dose rate (beta + gamma + neutron) at any point no greater than 200 milliroentgen equivalent man per hour ( $\mathrm{mrem} / \mathrm{hr}$ ). Neutron contributions to the total payload container dose rate shall be reported separately in the data package. The external dose rate of the loaded TRUPACT-II to be transported is limited to $200 \mathrm{mrem} / \mathrm{hr}$ at contact and $10 \mathrm{mrem} / \mathrm{hr}$ at 2 meters, as specified in Section 12.0 of the TRAMPAC. TRUPACT-II shipments also must comply with requirements specified in 10 CFR $\$ 71.47$. Supplemental shielding can be used to limit the dose rate for as low as reasonably achievable programs, but not to meet dose rate restrictions for the TRUPACT-II.

\subsubsection{Compliance and Verification}

An RCT uses survey instruments calibrated with NIST traceable sources to measure the dose rate at contact and at $2 \mathrm{~m}$ for loaded TRUPACT-II waste payload containers following Release Survey (WRP1-OP-1209), Radioactive Material Shipment and Receipt Surveys (WRP1-OP-1201), and Receive and Load TRUPACT Containers (WRP1-OP-0521), and in compliance with the Hanford Site Radiological Control Manual (Hanford 1994). TRUPACT-II shipments also must comply with requirements specified in $10 \mathrm{CFR} \$ 71.47$. If the RCT identifies containers exceeding the dose rate limits, loading personnel unload the TRUPACT-II, reconfigure the payload, and remeasure the dose rate to demonstrate compliance with the dose rate criteria. If necessary, loading personnel segregate nonconforming containers and repackage them in accordance with Transuranic Waste Repackaging, Visual Examination, and Sampling (WMH-400, Section 7.1.3). The CO confirms the contact dose rate in accordance with Transuranic Waste Transportation and Disposal Certification (WMH-400, Section 7.1.8).

\subsubsection{Thermal Power}

\subsubsection{Requirements}

Individual CH TRU waste payload containers in which the average thermal power density exceeds $0.1 \mathrm{~W} / \mathrm{ft}^{3}\left(3.5 \mathrm{~W} / \mathrm{m}^{3}\right)$ shall have the thermal power recorded in the data package. The thermal limit for the total decay heat from all CH TRU waste payload containers in a TRUPACT-II is $40 \mathrm{~W}$. The limits defined for decay heat in Section 3.5.1.1 of this certification plan also apply. 


\subsubsection{Compliance and Verification}

Program personnel calculate the average thermal power density of the CH TRU waste container in accordance with the methodology in Section 10.0 of the TRAMPAC manually or using computational algorithms. Program personnel validate and verify calculation programs in accordance with TRU Software Quality Assurance (WMH-400, Section 6.1.1) before the software is used as part of the Program. Decay heat compliance and verification methods for individual payload containers are discussed in Section 3.5.1. Decay heat compliance and verification methods for TRUPACT-II payloads are discussed in Section 4.8. Program personnel document the thermal power if the average thermal power density of the individual payload containers exceed $0.1 \mathrm{~W} / \mathrm{ft}^{3}$. Assay reports containing thermal power data are submitted in testing batch data reports to the site project office. The CO confirms thermal power density in accordance with Transuranic Waste Transportation and Disposal Certification (WMH-400, Section 7.1.8).

\subsubsection{TRU Alpha Activity Concentration}

\subsubsection{Requirements}

For purposes of defense CH TRU waste certification, the lower limit of $>100$ nanocuries/gram (nCi/g) of TRU radionuclides in the waste shall be interpreted as $>100 \mathrm{nCi}$ per gram of waste matrix. The weight of added external shielding and the payload containers (including any rigid liners) shall be subtracted prior to performing the $\mathrm{nCi} / \mathrm{g}$ calculation. A propagated measurement error shall be included in the calculation of the lower limit of activity concentration (e.g., measurement plus error $>100 \mathrm{nCi} / \mathrm{g}$ ). Only defense TRU waste or defense TRU mixed waste is acceptable for disposal in the WIPP. Documented evidence from assay data shall exist to show that the TRU alpha activity concentration of any defense $\mathrm{CH}$ TRU waste payload container is greater than $100 \mathrm{nCi} / \mathrm{g}$ of waste matrix.

\subsubsection{Compliance and Verification}

NDA personnel measure TRU alpha activity concentration in accordance with one or more of the radioassay procedures listed in Appendix A. NDA personnel calculate the TRU alpha activity concentration of the CH TRU waste container manually or using computational algorithms. NDA personnel validate and verify calculation programs in accordance with $T R U$ Software Quality Assurance (WMH-400, Section 6.1.1) before the software is used as part of the Program. Assay data are validated and verified in accordance with Data Management for NDE/NDA Results (WMH-350, Section 2.3) and submitted in batch data reports to the site project office. The CO confirms TRU alpha activity in accordance with Transuranic Waste Transportation and Disposal Certification (WMH-400, Section 7.1.8). Program personnel manage waste containers with TRU alpha activity concentrations that do not exceed $100 \mathrm{nCi} / \mathrm{g}$ as low-level waste. 


\subsection{CHEMICAL PROPERTIES CRITERIA AND REQUIREMENTS-CH TRU WASTE}

\subsubsection{Pyrophoric Materials}

\subsubsection{Requirements}

Pyrophoric materials other than radionuclides shall be rendered safe prior to placement in the CH TRU waste payload container by mixing them with chemically stable materials (e.g., concrete, glass) or shall be processed to remove their hazardous properties. Not more than one percent by weight of the CH TRU waste payload in each payload container shall be pyrophoric forms of radionuclides, and these shall be generally dispersed in the payload. Nonradionuclide pyrophorics are not allowed.

The one percent limitation on radionuclides is to allow for any minor residues of uranium or plutonium that may remain in an unoxidized state in the payload. The CH TRU wastes expected to contain metallic radionuclides are to be treated (oxidized) to eliminate as much of the potential pyrophorics as possible prior to placement in payload containers. A validated process that converts radionuclide pyrophoric compounds to a nonpyrophoric form may be used to meet this requirement. This process may either change the chemical form of the pyrophoric material or mix and bind it within an inert matrix.

\subsubsection{Compliance and Verification}

The Hanford Site limits radionuclide pyrophorics to not more than one percent by weight and requires processing of $\mathrm{CH}$ TRU wastes containing nonradionuclide pyrophoric materials to remove their hazardous properties prior to emplacement in payload containers. Program personnel compile, record, and evaluate acceptable knowledge in accordance with Acceptable Knowledge Documentation Management (WMH-400, Section 7.1.9). Program personnel review acceptable knowledge, including sampling and analysis data, documentation of waste stream descriptions, or actions to treat or stabilize the waste to eliminate specific characteristics, to verify that wasteproducing processes excluded or controlled pyrophoric materials. The CO confirms the pyrophorics criteria in accordance with Transuranic Waste Transportation and Disposal Certification (WMH-400, Section 7.1.8).

\subsubsection{Mixed Wastes}

\subsubsection{Requirements}

CH TRU waste shall contain hazardous constituents only as cocontaminants with transuranics (TRU mixed waste). All CH TRU mixed waste exhibiting corrosive, reactive, or ignitable characteristics shall be treated to remove the hazardous characteristic.

CH TRU waste shall be characterized as defined in the QAPP. Sites must determine whether their defense CH TRU waste is a mixed waste. The determination shall be based upon acceptable knowledge documentation and/or sampling and analysis data that indicate that the waste is hazardous as defined in 40 CFR Part 261, Subparts C and D. Each CH TRU mixed waste payload container must be assigned one or more EPA hazardous waste numbers. Only EPA hazardous waste numbers listed in the WIPP RCRA Part B Permit Application may be managed at WIPP. Table 3-4 lists the WIPP acceptable EPA hazardous waste numbers. 
Table 3-4. EPA Hazardous Waste Numbers Acceptable at WIPP.

\begin{tabular}{lll}
\hline F001 & D008 & D030 \\
F002 & D009 & D032 \\
F003 & D010 & D034 \\
F004 & D011 & D035 \\
F005 & D018 & D036 \\
F006 & D019 & D037 \\
F007 & D021 & D038 \\
F009 & D022 & D039 \\
D004 & D026 & D040 \\
D005 & D027 & D043 \\
D006 & D028 & P015 \\
D007 & D029 & \\
\hline
\end{tabular}

Source: Table 3.4.2.3-2, WIPP WAC (Revision 5, Change Notice No. 1).

\subsubsection{Compliance and Verification}

Program personnel review acceptable knowledge information documenting that waste does not exhibit corrosive, reactive, or ignitable characteristics and/or require treatment to remove these hazardous characteristics, and to verify that waste production processes included no corrosives, reactives, or ignitables. Program personnel implement QAPjP requirements and one or more of the procedures identified in Appendix A to characterize waste streams through headspace gas and solidified waste sampling and analysis. For homogeneous waste streams, toxicity characteristic and spent solvent EPA hazardous waste numbers are assigned based upon the analytical results and acceptable knowledge. For debris waste, EPA hazardous waste numbers are assigned based on acceptable knowledge. Toxicity characteristic (TC) EPA hazardous waste numbers are assigned to debris waste streams based on headspace gas sampling and analytical results if acceptable knowledge indicates the waste might contain a TC constituent in excess of the TC regulatory level. If data are insufficient to demonstrate that the concentration of the constituent is less than the TC regulatory level, the TC EPA hazardous waste number for the identified constituent is applied to the waste stream. The SPM (or designee) reviews the analytical data to ensure that chemical constituents in the waste are allowable according to the Chemical Lists in Appendix B of the TRUPACT-II SARP. At the discretion of the SPM, additional sampling of the waste stream from which any nonconforming container originated may be performed to determine whether the container is anomalous or is representative of the entire waste stream.

Program personnel identify hazardous constituents in CH TRU wastes and record the data in accordance with applicable data management procedures. The SQAO (or designee) verifies that data are entered in the WWIS. The CO confirms the mixed waste criteria in accordance with Transuranic Waste Transportation and Disposal Certification (WMH-400, Section 7.1.8). 


\subsubsection{Chemical Compatibility}

\subsubsection{Requirements}

CH TRU mixed waste must not contain chemicals that would cause adverse reactions with other payload containers during handling or disposal. The CH TRU mixed waste must be compatible with its container and packaging materials as well as other waste.

\subsubsection{Compliance and Verification}

Program personnel ensure compliance with the compatibility requirements using acceptable knowledge documentation. The TCO verifies chemical compatibility by comparing payload container inventory with approved TRUCON codes using Tables 5-1 through 5-6 of the TRAMPAC in accordance with Receive and Load TRUPACT Containers (WRP1-OP-0521). The CO confirms chemical compatibility criteria in accordance with Transuranic Waste Transportation and Disposal Certification (WMH-400, Section 7,1,8).

\subsubsection{Hazardous Constituents}

\subsubsection{Requirements}

The type and quantity of hazardous constituents on the target analyte lists, as described in the QAPP, and tentatively identified compounds (TICs) must be recorded in the site's data package and reported in the WWIS database.

\subsubsection{Compliance and Verification}

Program personnel determine the type and quantity of hazardous constituents and TICs through acceptable knowledge information and analytical results as described in Section 3.4.2. Program personnel document the types and quantities of the hazardous components in the CH TRU mixed wastes in accordance with applicable data management procedures. The SQAO (or designee) verifies that data are recorded in the WWIS. The CO confirms the hazardous constituents in accordance with Transuranic Waste Transportation and Disposal Certification (WMH-400, Section 7.1.8).

\subsubsection{Explosives, Corrosives, and Compressed Gases}

\subsubsection{Requirements}

The CH TRU waste payload shall contain no explosives (49 CFR $\$ 173.50$ ), corrosives (49 CFR $\$ 173.136$ ), compressed gases (49 CFR $\$ 173.115$ ), or pressurized containers and no ignitable, corrosive, or reactive wastes (as defined by 40 CFR $\$ \$ 261.21,261.22$, and 261.23 , respectively). Explosive materials, if present, must be treated or diluted such that a detonation is not possible. Corrosive materials, if present, must be treated to render them noncorrosive. 


\subsubsection{Compliance and Verification}

The Hanford Site prohibits explosives, compressed gases, and untreated corrosives in TRU waste containers. Program personnel compile, record, and evaluate acceptable knowledge in accordance with Acceptable Knowledge Documentation Management (WMH-400, Section 7.1.9) documenting that waste-producing processes do not contain explosives, corrosives, compressed gases, or pressurized containers and/or require the waste to be treated or diluted such that detonation is impossible and the waste is noncorrosive. Acceptable knowledge information is verified through NDE and/or visual examination. Program personnel record data regarding prohibited items and submit data reports to the SQAO. The CO verifies this information on the $\mathrm{CH}$ TRU Waste Certification Statement, in accordance with Transuranic Waste Transportation and Disposal Certification (WMH400, Section 7.1.8).

\subsubsection{Polychlorinated Biphenyl Concentration}

\subsubsection{Requirements}

TRU waste with polychlorinated biphenyl (PCB) concentrations equal to or greater than 50 ppm is not allowed for disposal in the WIPP. For CH TRU organic sludges, statistical selection, sampling, and analysis for PCBs must be performed in accordance with the QAPP. If transformer oils containing PCBs are identified in a waste stream, these wastes shall be examined for PCBs. Acceptable knowledge may be used to characterize debris waste. Knowledge of the operations that generated these wastes is used to determine whether the waste comes from a process where PCBs are a possible waste component.

\subsubsection{Compliance and Verification}

Program personnel sample containers of homogeneous TRU waste with potential PCB contamination. Analytical facility personnel analyze the samples. Sampling and analysis is conducted in accordance with applicable procedures specified in the QAPJP. For debris waste, Program personnel compile, record, and evaluate acceptable knowledge in accordance with Acceptable Knowledge Documentation Management (WMH-400, Section 7.1.9) to demonstrate compliance with the PCB requirement. The CO verifies that PCB levels comply with requirements and documents this on the CH TRU Waste Certification Statement in accordance with Transuranic Waste Transportation and Disposal Certification (WMH-400, Section 7.1.8).

\subsection{GAS GENERATION CRITERIA AND REQUIREMENTS- CH TRU WASTE}

\subsubsection{Decay Heat}

\subsubsection{Requirements}

Because of gas generation concerns, there is a wattage limit for individual payload containers and a wattage limit for the TRUPACT-II payload assembly. These wattage limits are presented in the TRUPACT-II SARP, Section 1.2.3.3.8. If the decay heat is less than the limits for the specified payload shipping category, the payload meets the payload assembly compliance limit for decay heat. If individual payload containers exceed the limit, these containers must be tested in accor- 
dance with Attachment 2.0 of the TRAMPAC, "Gas Generation Test Plan to Qualify Test Category Waste for Shipment in the TRUPACT-II."

Calculations shall be performed as specified in Section 10.0 of the TRAMPAC. Documented evidence shall exist to show that individual $\mathrm{CH}$ TRU waste payload containers and the total payload assembly to be transported meet the decay heat limits specified in the TRUCON for the appropriate shipping category.

\subsubsection{Compliance and Verification}

NDA personnel use the isotopic composition radioassay data to calculate the decay heat of the CH TRU waste container in accordance with the methodology in Section 10.0 of the TRAMPAC. NDA personnel calculate decay heat and verify calculations using QC checks or use computational algorithms programmed into the software used. Program personnel validate and verify the calculation program in accordance with TRU Software Quality Assurance (WMH-400, Section 6.1.1) before the software is used as part of the Program. Individual payload containers exceeding the limit are tested in accordance with Attachment 2.0 of the TRAMPAC, "Gas Generation Test Plan to Qualify Test Category Waste for Shipment in the TRUPACT II." NDA personnel record decay heat calculations and submit radioassay testing batch data reports to the SQAO. The TCO verifies that the decay heat of the loaded TRUPACT-II meets the limit specified in the TRUCON for the appropriate shipping category in accordance with Receive and Load TRUPACT Containers (WRP1-OP-0521). The CO confirms decay heat criteria in accordance with Transuranic Waste Transportation and Disposal Certification (WMH-400, Section 7.1.8). Program personnel repackage nonconforming waste containers in accordance with Transuranic Waste Repackaging, Visual Examination, and Sampling (WMH-400, Section 7.1.3).

\subsubsection{Flammable Volatile Organic Compounds}

\subsubsection{Requirements}

The total concentration of potentially flammable volatile organic compounds (VOCs) is limited to $500 \mathrm{ppm}$ in the headspace of a CH TRU waste payload container, as specified in Section 5.0 of the TRAMPAC.

\subsubsection{Compliance and Verification}

Program personnel sample headspace gases and have them analyzed in accordance with methods specified in the QAPjP. Analytical personnel determine the total concentration of potentially flammable VOCs in the headspace of a CH TRU waste container in accordance with one or more of the analytical procedures identified in Appendix A. TRUPACT-II loading personnel accept and load only payload containers that do not exceed flammable VOC requirements. The CO confirms the flammable VOC criteria in accordance with Transuranic Waste Transportation and Disposal Certification (WMH-400, Section 7.1.8). Program personnel identify containers that exceed VOC requirements, segregate them, and ensure that the noncompliant containers are repackaged in accordance with Transuranic Waste Repackaging, Visual Examination, and Sampling (WMH-400, Section 7.1.3). 


\subsubsection{Volatile Organic Compound Concentrations}

\subsubsection{Requirements}

No wastes shall be managed at WIPP which contain headspace gas VOC concentrations resulting in emissions not protective of human health and the environment. Table 3-5 lists the VOCs and limits for an average concentration in a repository room. A container that has been analyzed and reported to contain higher VOC concentrations than the average limits may be approved for disposal by the WIPP management and operating (M\&O) contractor on a case-by-case basis. Approval for containers exceeding the average limits will be done by the WWIS exception process. Sites shall report the results of VOC headspace gas sampling for each TRU waste payload container using the WWIS. VOC concentration levels, as reported, will be evaluated by the WIPP M\&O contractor to ensure that VOC averages for each repository room do not exceed the limits defined in Table 3-5.

Table 3-5. VOC Concentration Limits for CH TRU Waste Payload Containers.

\begin{tabular}{|c|c|}
\hline Compound & $\begin{array}{l}\text { Average Headspace Gas } \\
\text { Concentration Limits (ppm) }\end{array}$ \\
\hline Carbon tetrachloride & $.7,510$ \\
\hline Chlorobenzene & 17,600 \\
\hline Chloroform & 6,325 \\
\hline 1,1-Dichloroethylene ${ }^{a}$ & 500 \\
\hline 1,2-Dichloroethane & 500 \\
\hline Methylene chloride & 100,000 \\
\hline 1,1,2,2-Tetrachloroethane & 7,924 \\
\hline Toluene & 41,135 \\
\hline 1,1,1-Trichloroethane & 100,000 \\
\hline
\end{tabular}

a Although WIPP WAC allowable levels are higher for these potentially flammable VOCs, the more restrictive requirements listed here from the TRAMPAC, Section 5.2.5 must be followed.

Source: Table 3.5.3.3, WIPP WAC (Revision 5, Change Notice No. 1) and TRAMPAC, Section 5.2.5.

\subsubsection{Compliance and Verification}

Headspace gas samples are collected and analyzed in accordance with methods specified in the QAPjP and procedures referenced in Appendix A. Program personnel compare the headspace gas analytical results to the VOC concentration limits in Table 3-5 and report the results to CAO via the WWIS. If the VOC concentration limits are higher than the average limits allowed, the SPM for designee) reports the results to $\mathrm{CAO}$ and use the WWIS exception process to request evaluation and approval by the WIPP M\&O contractor on a case-by-case basis. The CO confirms VOC concentrations in accordance with Transuranic Waste Transportation and Disposal Certification (WMH-400, Section 7.1.8). Program personnel identify waste containers that are rejected because they do not meet the VOC concentration limits and repackage the nonconforming containers in accordance with Transuranic Waste Repackaging, Visual Examination, and Sampling (WMH-400, Section 7.1.3). 


\subsubsection{Aspiration}

\subsubsection{Requirements}

Sites adding filters to unvented payload containers of $\mathrm{CH}$ TRU waste shall, prior to transport, aspirate the payload containers according to documented procedures for a sufficient period of time to ensure equilibration of any potentially flammable gases that may have accumulated in the closed containers. Required aspiration times are listed in the TRUPACT-II SARP, Appendix 3.6.11, and the TRUCON, Tables 7-1 through 9-3. Options for determining aspiration time include determination based on the date of drum closure and headspace gas sampling at the time of venting or during aspiration.

\subsubsection{Compliance and Verification}

Program personnel aspirate waste containers in accordance with Sampling Design and Data Analysis for RCRA Characterization and Visual Examination of Retrievably Stored Transuranic Waste (WMH-400, Section 7.1.4) for the duration specified in the TRUPACT-II SARP, Appendix 3.6.11, and the TRUCON, Tables 7-1 through 9-3, prior to loading into a TRUPACT-II. The TCO verifies that waste containers have been aspirated and documents this on the PCTCD. The CO confirms aspiration times in accordance with Transuranic Waste Transportation and Disposal Certification (WMH-400, Section 7.1.8).

\subsubsection{Shipping Category}

\subsubsection{Requirements}

All CH TRU waste payload containers in a single TRUPACT-II shall belong to the same shipping category, as defined in Section 13.0 of the TRAMPAC. Each payload container shall meet the definition of one of the content codes in the TRUCON. Section 3.2.4 discusses container marking requirements for shipping categories.

\subsubsection{Compliance and Verification}

Program personnel assign TRUCON codes and shipping categories to waste containers based on the waste type and packaging configuration determined through acceptable knowledge and characterization resuits. The TCO verifies proper assignment and loading of the TRUPACT-II in accordance with Receive and Load TRUPACT Containers (WRP1-OP-0521), and documents this on the PCTCD and Payload Assembly Transportation Certification Document (PATCD) (see Appendix E). See Section 3.2.4 for container marking requirements for shipping categories. The $\mathrm{CO}$ confirms the shipping category in accordance with Transuranic Waste Transportation and Disposal Certification (WMH-400, Section 7.1.8).

\subsubsection{Confinement Layers}

\subsubsection{Requirements}

Documented procedures shall be used to ensure that the requirements specified in Section 8.0 of the TRAMPAC are met, including the following: 
- Rigid 55-gal. drum liner, if present, shall be punctured or have a filter vent.

- Maximum number of confinement layers for the waste shall be known and shall comply with the TRUCON.

- Bags shall be closed by one of the following methods:

- Twist-and-tape closure

- Fold-and-tape closure

- Heat-sealed, provided a minimum of one filter vent is present on the bag

- Sealed containers $>4 \mathbf{L}$ are prohibited, except for Waste Material Type II. 2 packaged in a metal container.

\subsubsection{Compliance and Verification}

Program personnel ensure compliance with the confinement layer requirements using acceptable knowledge information verified by NDE and/or visual examination. NDE and visual examination are conducted in accordance with methods specified in the QAPJP and described in procedures identified in Appendix A. The CO confirms confinement layers in accordance with Transuranic Waste Transportation and Disposal Certification (WMH-400, Section 7.1.8).

\subsection{DATA PACKAGE CRITERIA AND REQUIREMENTS-CH TRU WASTE}

\subsubsection{Acceptance Data}

\subsubsection{Requirements}

An auditable data package for each waste container with a signed certification statement attesting to the fact that the CH TRU waste meets the requirements of the current WIPP WAC shall be maintained at the site. This data package shall include, as a minimum:

- Container identification number

- Container assembly identification number (if applicable)

- Date of payload container certification

- WAC exception number (if applicable)

- Date of container closure

- Maximum contact dose rate in $\mathrm{mrem} / \mathrm{hr}$ and specific neutron dose rate

- Weight

- Payload container type

- Procurement or inspection records that containers meet requirements

- Assay information, including PE-Ci, alpha Ci, and Pu-239 FGE content

- Measured or calculated thermal power

- Shipment number

- Date of shipment

- Other information considered significant by the generator

- TRU alpha activity concentration

- Removable surface contamination 
TRUPACT-II Requirements

- Physical description of waste form (content code)

- TRUPACT-II number(s)

- Flammable headspace gas VOC concentration

- Headspace flammable gas concentration (hydrogen and methane)

- Date of TRUPACT-II closure

- Shipping category

Environmental Compliance Requirements

- Headspace gas VOC concentration

- PCB concentration (if applicable)

- Hazardous constituents (if applicable)

- EPA hazardous waste numbers (if applicable)

- Waste Stream Profile number

- Total VOC, semivolatile organic compound (SVOC), and metal concentrations (if applicable)

WWIS data shall be entered and transmitted to the WIPP and approved by the WIPP prior to shipping waste. Depending upon the waste form, some WWIS fields are not applicable or required. The signed and dated certification statement shall be maintained on file by the site. Waste characterization and waste certification data records shall be maintained as required by the QAPP and QAPD.

\subsubsection{Compliance and Verification}

Program personnel implement auditable data package requirements as described in the QAPjP and in accordance with implementing procedures identified in Appendix A. The SPM reviews the data package to ensure that the package is complete and correct.

The SQAO and SPM verify compliance with the data package requirements by reviewing data packages and waste certification statements in accordance with Transuranic Waste Project Level Data Validation and Verification (WMH-400, Section 7.1.6). The SQAO ensures that the WWIS data are entered into the system and the SPM transmits the data to the CAO for approval prior to waste shipment in accordance with WIPP Waste Information System Data Entry and Reporting (WMH-400, Section 7.1.5).

The CO confirms that the auditable data package is complete, and prepares and signs the $\mathrm{CH}$ TRU Waste Certification Checklist (see Appendix B) in accordance with Transuranic Waste Transportation and Disposal Certification (WMH-400, Section 7.1.8). (If the CO prepares the data package, another qualified individual reviews it.) If deficiencies are identified, the CO and SPM resolve any deficiencies and the data package is reviewed again. The $\mathrm{CO}$ maintains all signed $\mathrm{CH}$ TRU Waste Certification Checklists as quality records on file in accordance with TRU Records Management (WMH-400, Section 1.5.1). The TCO completes the data package, adding the shipment, payload, and dose rate information. 


\section{HNF-2600 Revision 0}

\subsubsection{RCRA Data}

\subsubsection{Requirements}

Sites shall prepare and transmit to the WIPP a WSPF for each waste stream in accordance with Appendix E of the WIPP WAC. Sites shall prepare a Uniform Hazardous Waste Manifest in accordance with 40 CFR $\$ 262.23$ and a LDR notification in accordance with 40 CFR Part 268 for each shipment of CH TRU mixed waste.

\subsubsection{Compliance and Verification}

When data are available to satisfy WIPP WAC requirements, the CO compiles the CAO data package. The SPM reviews the data package and prepares the WSPF in accordance with TRU Waste Characterization Data Quality Objectives Reconciliation and Reporting (WMH-400, Section 7.1.1). If complete, the SPM approves and transmits the package to CAO. If the SPM identifies a deficiency, the SPM and CO coordinate to resolve the deficiencies and the data package is reviewed again.

Program personnel prepare a Uniform Hazardous Waste Manifest and an LDR notification for each shipment that includes mixed waste in accordance with Transuranic Waste Transportation and Disposal Certification (WMH-400, Section 7.1.8). The SPM reviews the manifest and LDR notification for accuracy and completeness. If the SPM identifies a deficiency in the manifest or notification, the SPM returns the paperwork to the CO and TCO for resolution. If the manifest and LDR notification are accurate and complete, the TCO signs them and removes the generator copy of the manifest. The records management coordinator maintains the generator copy of the Uniform Hazardous Waste Manifest on file along with a copy of the LDR notification in accordance with TRU Records Management (WMH-400, Section 1.5.1).

\subsubsection{Shipping Data}

\subsubsection{Requirements}

Sites shall have procedures in place for certifying a TRUPACT-II payload in accordance with the TRAMPAC and DOT requirements. Sites shall prepare Bills of Lading for CH TRU waste shipments in accordance with 49 CFR Part 172, Subpart C, or a Uniform Hazardous Waste Manifest in accordance with 40 CFR $\$ 262.23$. Sites shall prepare a TRUPACT-II PCTCD in accordance with Section 13.0 of the TRAMPAC for each payload container prior to loading the container into a TRUPACT-II.

\subsubsection{Compliance and Verification}

The TCO prepares a TRUPACT-II PCTCD in accordance with Section 13.0 of the TRAMPAC for each payload container prior to loading the container into a TRUPACT-II. Transportation logistics personnel prepare a bill of lading or Uniform Hazardous Waste Manifest at the direction of the TCO. For non-mixed waste shipments, a bill of lading is prepared in accordance with the requirements of 49 CFR Part 172, Subpart C. A Uniform Hazardous Waste Manifest in prepared for mixed waste shipments in accordance with 40 CFR \$262.23. For TRU waste shipments that include mixed waste, a Uniform Hazardous Waste Manifest may be used in place of a bill of lading, as specified at 40 CFR $\$ 262.23$. Transportation procedures are included in TRU Transportation Logistics (WMH-400, Section 2.1.5). 
The TCO completes the PCTCD (Section 4.11) to certify an individual payload container and a PATCD to certify the payload assembly for shipping in accordance with Receive and Load TRUPACT Containers (WRP1-OP-0521) which is based on Section 13.0 of the TRAMPAC. The CO verifies compliance with shipping data requirements by reviewing the PCTCD, PATCD, Bill of Lading, or Uniform Hazardous Waste Manifest, and signing the CH TRU Waste Certification Statement in accordance with Transuranic Waste Transportation and Disposal Certification (WMH400, Section 7.1.8). Transportation packaging personnel perform final inspection and approval of the payload assembly and shipping documents. 


\subsection{HANFORD SITE COMPLIANCE PLAN FOR TRAMPAC}

This section comprises the Hanford Site Compliance Plan for TRAMPAC and describes $\mathrm{CH}$ TRU waste management practices and procedures used at the Hanford Site to demonstrate compliance with the TRAMPAC. The Hanford Site must demonstrate compliance with TRAMPAC transportation requirements before TRU wastes can be shipped from the Hanford Site in the TRUPACT-II, a Type $\mathrm{B}$ package certified for transporting $\mathrm{CH}$ TRU wastes. This Compliance Plan demonstrates compliance with TRAMPAC requirements, which include the following:

- Payload classification and assignment of shipping categories

- Physical form of the waste

- Chemical properties of the waste

- Chemical compatibility

- Gas distribution and pressure buildup

- Payload container and contents configuration

- Isotopic inventory and fissile content

- Decay heat

- Weight and center of gravity

- Radiation dose rates

- Payload assembly criteria

This section is organized so that the TRAMPAC requirement is summarized followed by descriptions of the Hanford Site methods of compliance and verification. Appendix A summarizes the WIPP WAC and TRAMPAC requirements and identifies applicable Hanford Site documents and procedures that implement each requirement. Appendix A is organized to correlate with section numbering for WIPP WAC requirements; therefore, the compliance and verification sub-sections of Section 4.0 are cross-referenced to the applicable WIPP WAC requirements listed in Appendix A. Please note that RTR and assay requirements are spelled out in Sections 9 and 10 (respectively) of the QAPjP (HNF-2599 Revision 0).

If a requirement is not met, Program personnel segregate the nonconforming item and initiate an NCR or report the nonconformance in accordance with TRU Nonconforming Item Reporting and Control (WMH-400, Section 1.3.2). Corrective action will be taken in accordance with $T R U$ Corrective Action Management (WMH-400, Section 1.3.1) to resolve nonconformances. (See Section 5.3 for more information about nonconformances.)

\subsection{PAYLOAD CLASSIFICATION AND ASSIGNMENT OF SHIPPING CATEGORIES}

As required by the TRUPACT-II SARP, Section 1.2.3, as referenced in Section 3.0 of the TRAMPAC, all waste containers to be transported in the TRUPACT-II must be assigned to a specific shipping category based on the physical and chemical characteristics of the waste and the packaging configuration used. Assigning a waste to the appropriate shipping category is necessary to ensure that waste is shipped under transportation conditions that meet the requirements of the current version of the TRUPACT-II SARP. In accordance with the TRUCON Codes document, which describes the content code system for shipping CH TRU waste in a TRUPACT-II, each waste container shipped to WIPP must be assigned an approved TRUCON code based on the waste contents and packaging method. 


\subsubsection{Designation of Shipping Category}

\subsubsection{Requirements}

The shipping category is denoted by a series of alphanumeric characters that indicate the type of waste, type of container used to package the waste, and the number and type of confinement layers present in the payload container. The shipping category is in the form, N.n1Xn2, where

$\mathrm{N} \quad=\mathrm{A}$ Roman numeral (I to IV) that describes the physical form of the waste and is termed the "Waste Type" (see Table 4-1)

$\mathrm{n} 1=\mathrm{A}$ number $(1,2$, or 3$)$ denoting cases where further division of the waste type has been made based on the gas-generating potential of the waste (these subcategories of the waste type are termed "Waste Material Types") (see Table 4-1)

$\mathrm{X}=\mathrm{A}$ capital letter (A, B, C, or D) that designates the payload container and, if applicable, the overpacking configuration (see Table 4-2)

$\mathrm{n} 2=$ An alpha or numeric character that denotes the number of bag layers or type of containment of the waste. The number of plastic layers is indicated by a numeral ( 0 through 6 ). The letter $M$ is used when the waste is placed directly in a metal can as the innermost layer of confinement.

A T (for "Test Category") placed at the end of a shipping category indicates a shipping category that cannot be shipped without first performing a test to verify a container's actual gas generation rate. The required testing is described in the TRAMPAC. All other shipping categories are referred to as analytical shipping categories.

Shipping category III.1A3 is an example denoting a solid organic waste packaged with a maximum of three layers of confinement inside of a drum. (Further details on the definition of shipping categories are provided in the TRUPACT-II SARP).

\subsubsection{Compliance and Verification}

Wastes generated at the Hanford Site have been categorized into several waste streams, as described in the Transuranic Waste Baseline Inventory Report (DOE 1995b) (TWBIR). The TRUCON lists Hanford Site waste streams and their associated waste material types for waste that have been assigned a TRUCON code. The shipping category is assigned based on acceptable knowledge and/or visual inspection and is verified by NDE. The assigned shipping category must match a TRUCON for Hanford. The TCO verities the shipping category of each payload container before certification for shipment to WIPP and documents this according to the instructions for completing the PCTCD and PATCD, in accordance with Transuranic Waste Transportation and Disposal Certification (WMH400, Section 7.1.8).

See also Appendix A, column "WIPP WAC and Certification Plan Section," row 3.5.5, which contains the titles of applicable procedures that implement the requirements of this section. 
Table 4-1. TRU Waste Types and Corresponding Waste Material Types.

\begin{tabular}{|c|c|c|}
\hline $\begin{array}{l}\text { Waste } \\
\text { Type }\end{array}$ & $\begin{array}{l}\text { Waste Material } \\
\text { Type }\end{array}$ & Description \\
\hline \multirow[t]{4}{*}{ I } & & $\begin{array}{l}\text { SOLIDIFIED AQUEOUS OR HOMOGENEOUS INORGANIC } \\
\text { SOLIDS }\end{array}$ \\
\hline & I.1 & Solidified inorganic liquids \\
\hline & I. 2 & Soils or sludges \\
\hline & 1.3 & Concreted inorganics \\
\hline \multirow[t]{3}{*}{ II } & & SOLID INORGANICS \\
\hline & II. 1 & Solid inorganics in plastic packaging \\
\hline & II.2 & Solid inorganics in metal can \\
\hline III & III. 1 & SOLID ORGANICS \\
\hline IV & IV.1 & SOLIDIFIED ORGANICS \\
\hline
\end{tabular}

Source: Table 1.2.3.2-3, TRUPACT-II SARP (Revision 14).

Table 4-2. Approved Payload Container and Configuration Definitions.

\begin{tabular}{|c|c|c|c|}
\hline $\begin{array}{l}\text { Primary } \\
\text { Payload } \\
\text { Container }\end{array}$ & Description & $\begin{array}{l}\text { TRUPACT-II } \\
\text { Payload } \\
\text { Configuration }\end{array}$ & $\begin{array}{l}\text { Shipping } \\
\text { Category Alpha } \\
\text { Designator }\end{array}$ \\
\hline 55-gal. drum & $\begin{array}{l}\text { Drums with materials in additional layers } \\
\text { of confinement (e.g., rigid liner[s], } \\
\text { bag[s], and can[s]) }\end{array}$ & $\begin{array}{l}2 \text { seven-packs } \\
\text { (14 drums) }\end{array}$ & A \\
\hline SWB & $\begin{array}{l}\text { Overpacks of drums (up to four) placed } \\
\text { in an SWB }\end{array}$ & 2 SWBs & B \\
\hline SWB & $\begin{array}{l}\text { SWB with material in additional layers of } \\
\text { confinement (e.g., bag[s] and can[s]) }\end{array}$ & 2 SWBs & C \\
\hline SWB & $\begin{array}{l}\text { Overpack of an experimental bin in an } \\
\text { SWB }\end{array}$ & 2 SWBS & D \\
\hline Pipe overpack & $\begin{array}{l}\text { Pipe overpack assembly overpacked in a } \\
55 \text {-gal. drum }\end{array}$ & $\begin{array}{l}14 \text { pipe overpacks in } 55- \\
\text { gal. drums }\end{array}$ & E \\
\hline TDOP & $\begin{array}{l}\text { Up to } 1055 \text {-gal. drums or } 1 \text { SWB, or } 1 \\
\text { experimental bin overpacked in an SWB }\end{array}$ & 1 TDOP & $\begin{array}{l}\text { Apply appropriate } \\
\text { shipping category } \\
\text { designator based on } \\
\text { type of payload } \\
\text { container in the } \\
\text { TDOP }\end{array}$ \\
\hline
\end{tabular}

Source: Section 1.2.3.2.4 and Table 1.2.3.2-4, TRUPACT-II SARP (Revision 16). 


\subsubsection{Designation of TRUCON Codes}

\subsubsection{Requirements}

Each waste form at a given site is also characterized by its contents and packaging method and must be assigned a TRUCON code. The TRUCON, referenced by the "Certificate of Compliance" for the TRUPACT-II, presents a description of each TRU waste form at each site and is used to establish a TRUCON code and a corresponding shipping category for each waste form.

Only CH TRU waste forms described under a content code in the TRUCON can be transported in the TRUPACT-II. Each approved payload container must be assigned to a shipping category and a TRUCON code, with the payload container contents and packaging configuration consistent with the TRUCON code and shipping category descriptions.

TRUCON codes are required to be in the form, RL $1 \mathrm{n} 1 \mathrm{X}$ or RL $2 \mathrm{n} 1 \mathrm{X}$, where

RL = Identifies the waste as being from the Hanford Site (other identifiers are used for other sites)

1 or $2=$ Provides a distinction between newly generated and retrievably stored waste. The " 100 " series denotes newly generated waste, and the " 200 " series is used for retrievably stored waste.

n1 $=$ A number from 11 to 29 that denotes different TRUCON codes based on the physical and chemical forms of the waste

$\mathrm{X}=\mathrm{A}$ letter that denotes the TRUCON code subcategory. The letters are used to further differentiate the waste form in terms of varying packaging configurations

\subsubsection{Compliance and Verification}

Program personnel review acceptable knowledge information on waste form and packaging methods used to assign TRUCON codes. NDE personnel verify the waste form and shipping category through NDE of all payload containers and visual examination of randomly selected payload containers following the procedures listed in Appendix A. The TCO verifies the waste form and TRUCON code of each payload container before certification for shipment to WIPP and documents this on the PCTCD and PATCD in accordance with Transuranic Waste Transportation and Disposal Certification (WMH-400, Section 7.1.8).

If a TRUCON code has not been assigned to the waste in the container, Program personnel assign the appropriate TRUCON code based on the waste stream characterization information as described in the TRUCON. If the waste is not listed in the correlation tables of the TRUCON or if there is no corresponding TRUCON code listed in the TRUCON, the payload container is not eligible for shipment.

See also Appendix A, column "WIPP WAC and Certification Plan Section," row 3.5.5, which contains the titles of applicable procedures that implement the requirements of this section. 
HNF-2600 Revision 0

\subsection{PHYSICAL FORM OF THE WASTE}

\subsubsection{Requirements}

In accordance with Section 4.0 of the TRAMPAC, the physical form of waste constituting the TRUPACT-II payload is restricted to solid or solidified materials. Liquid waste is prohibited, except for residual amounts in well-drained containers. The total volume of residual liquid in a payload container is restricted to less than one volume percent and not more than 1 in. in any container. In addition, sharp or heavy objects must be blocked, braced, or suitably packaged to provide puncture protection.

Sealed containers are prohibited from being included as part of the waste, except for containers $4 \mathrm{~L}$ or less in size. Containers greater than $4 \mathrm{~L}$ in size may be present only if there is verifiable evidence that they are not sealed (e.g., visible absence of a cap or presence of a puncture in the container). Metal cans with roll-seam closures cannot be used for waste types I and II because they are air tight (Appendix 1.3.6 of the TRUPACT-II SARP). Pressurized containers are also prohibited.

The physical waste form in each payload container must be identified, and prohibited physical waste forms must be excluded from payload containers. For newly generated waste, physical waste form identification is accomplished by either visual examination or NDE (e.g., radiography), or both. A second, independent verification of the physical waste form must be performed prior to transport for no less than 10 percent of the payload containers transported from the site per year. For retrievably stored waste, a combination of acceptable knowledge and verification, using real-time radiography (RTR) or a waste sampling program, must be used.

Visual examination personnel must inspect for and remove from the waste all prohibited waste forms. Independent verification must occur either visually prior to closure of the payload container or by NDE after the payload container is closed. When the verification occurs prior to closing the payload container, a second visual examiner (or QA inspector), other than the original examiner who filled the payload container, must inspect the waste and verify that the physical waste form is in compliance with the transport requirements. The second examiner must document this verification by aftixing signature, initials, or stamp to the payload container data sheet.

\subsubsection{Compliance and Verification}

The Hanford Site does not generate CH TRU waste forms other than solid or solidified materials for transportation off site. Waste generators remove prohibited physical waste forms from the waste prior to packaging. Waste generators process items such as pressurized or sealed containers to eliminate any condition that may result in rejection of the payload container. The generator verifies that the waste placed in the container meets the physical form requirements.

Program personnel ensure compliance with the physical form requirements through acceptable knowledge verified by radiography of the payload container contents prior to certification. Retrievably stored waste containers from all matrix parameter categories are randomly selected and visually examined as a QC check on radiography. The specific methodology for certifying retrievably stored waste, based on the use of acceptable knowledge, radiography, and/or visual examination, is described in the TRUCON document for each content code, the QAPJP, Hanford Site Transuranic Waste Sampling Plan (Hanford 1998c), and applicable implementing procedures. See also Appendix 
A, column "WIPP WAC and Certitication Plan Section," rows 3.2.7 and 3.4.5, which contain the titles of applicable procedures that implement the requirements of this section. A payload container rejected for noncompliance with the physical form requirements is marked and segregated or the noncompliant item is removed and the container is repackaged and reprocessed to verify remaining certification requirements.

\subsection{CHEMICAL PROPERTIES OF THE WASTE}

The chemical properties of the waste are determined by the chemical constituents allowed in a given waste type (e.g., solidified aqueous or homogeneous inorganic solids are Waste Type I). These constituents are restricted so that all payload containers are safe for handling and transport. Specific requirements on the chemical properties of the waste are described below. As required by the TRUPACT-II SARP, potential changes that may require reclassification of a given waste form into a different waste type will be documented in a revision to the TRUCON, which will be submitted for formal approval by the NRC. Specific requirements in these areas are described in the following sections.

\subsubsection{Prohibited Waste Items}

\subsubsection{Requirements}

As defined in Section 5.0 of the TRAMPAC, four types of chemical constituents are prohibited from a TRUPACT-II payload: (1) explosives, (2) nonradioactive pyrophorics, (3) corrosives, and (4) flammable VOCs:

- An explosive is "any chemical compound, mixture, or device, the primary or common purpose of which is to function by explosion (i.e., with substantial instantaneous release of gas and heat)." Examples of explosives are ammunition, dynamite, black powder, detonators, nitroglycerin, urea nitrate, and picric acid.

- A pyrophoric is "a flammable solid which, under transport conditions, might cause fires through friction or retained heat, or, which can be ignited readily, and when ignited, burns vigorously and persistently so ds to create a serious transportation hazard." This includes spontaneously combustible materials, water reactive materials, and oxidizers. Pyrophoric radioactive materials may be present only in a small residual amount (i.e., less than 1 weight percent) in payload containers.

- A corrosive is an aqueous material that has a pH less than 2 or more than 12.5. Acids and bases that are potentially corrosive must be neutralized and rendered noncorrosive prior to being a part of the waste.

- A flammable VOC has an NFPA Flammability Hazard Degree of 3 or 4 and a flash point of less than $100^{\circ} \mathrm{F}$, or is considered by the EPA to be a significant fire hazard under WIPP repository conditions.

Typically, waste-generating sites administratively control and monitor the procurement, distribution, use, and disposal of explosive materials through site-specific operating and QA 
procedures. Additionally, waste-generating processes must be assessed for safety hazards such as potential explosion hazards and potential inadvertent production of explosive materials.

Nonradioactive pyrophorics are subject to the same controls as explosives (i.e., procurement controls, operational and QA procedures, and safety assessments). Operating procedures must require that pyrophoric material be rendered chemically safe by processing prior to being placed into a payload container or the pyrophoric material shall be segregated from the waste form and excluded from the payload container.

Corrosives must be either excluded from the payload container or processed to neutralize the corrosive material, or otherwise render it noncorrosive. Process-specific operating procedures describe the specific actions required to ensure compliance with the corrosive material prohibition. (See also Sections 3.4.2.1 and 3.4.5.1, which prescribe requirements prohibiting ignitable, corrosive, or reactive wastes in payload containers.)

The total amount of potentially flammable organics that can occur in the headspace of a payload container shall be limited to $500 \mathrm{ppm}$. The limit on flammable VOCs will be met either by means of process controls or by suitable sampling programs (see Section 4.3.2.1).

\subsubsection{Compliance and Verification}

The Hanford Site does not allow the mixing of explosives and TRU waste. Nonradionuclide pyrophoric materials at the Hanford Site are subject to procurement controls and safety assessments. In general, the Hanford Site does not permit pyrophoric materials in TRU waste process areas. If a process requires the use of pyrophoric materials, the quantity of pyrophoric materials that enters the process is limited and controlled and the waste must be treated to render it chemically safe prior to placement in a waste container. Explosives, compressed gases, pyrophorics, and corrosive liquids are prohibited from payload containers. Chemicals (e.g., oxidizers) capable of forming explosive mixtures under some conditions are also prohibited from the waste.

Program personnel verify compliance with the prohibited items requirement by obtaining information (e.g., administrative, operating, and QA procedures and safety assessments) documenting that waste does not contain explosives, pyrophorics, or corrosives, and reviewing acceptable knowledge to verify that waste-producing processes included no pyrophorics, explosives, or corrosives. Acceptable knowledge includes sampling and analysis data, documentation of waste stream descriptions, or actions to treat or stabilize the waste to eliminate specific characteristics. See also Appendix A, column "WIPP WAC and Certification Plan Section," row 3.4.5, which contains the titles of applicable procedures that implement the requirements of this section. Program personnel verify that prohibited wastes are not in the waste container through visual examination of randomly selected waste containers.

\subsubsection{Restricted Chemical Constituents}

\subsubsection{Requirements}

Pyrophoric radionuclides and potentially flammable VOCs are restricted to specified levels for the TRUPACT-II payload, as follows: 
- Pyrophoric radionuclides may be present only in small residual amounts (less than one weight percent)

- The total amount of potentially flammable VOCs that can be present in the headspace of a payload container is restricted to $500 \mathrm{ppm}$

The content codes from DOE sites are grouped into waste types (e.g., solid inorganics are Waste Type II) and further divided into waste material types based on their gas generation potential which is quantified by the effective $G$ value (see Appendix 3.6.7 of the TRUPACT-II SARP). To conform to these limits, the chemicals and materials within a given waste material type are further restricted. These restrictions apply to all materials that are present in the waste in amounts greater than one weight percent.

The materials allowed within each waste type to conform with the bounding G-values (which quantify the gas-generation potential of the waste) are listed in Tables 4 through 8 of Appendix 3.6.7 of the TRUPACT-II SARP for Waste Types I, II, and III. (Presently, an effective G-value cannot be assigned to Waste Type IV, and this waste type has been assigned to the test category. Waste Type IV can be qualified for shipment only by gas generation testing of each individual payload container. The test procedures and controls for test category waste are discussed in Attachment 2.0 of the TRAMPAC).

\subsubsection{Compliance and Verification}

Program personnel verify that wastes are in compliance with the $500 \mathrm{ppm}$ flammable VOC limit through review of documentation of the chemical inputs and outputs. Program personnel review acceptable knowledge information to verify that waste-producing processes included no pyrophoric radionuclides greater than one weight percent. Program personnel obtain headspace gas samples from all containers in accordance with the procedures listed in Appendix A, and analytical laboratory personnel analyze headspace gas samples to verify that wastes are in compliance with the $500 \mathrm{ppm}$ flammable VOC limit. Analytical laboratory personnel determine VOCs, SVOCs, and metals in the waste matrix according to the approved procedures listed in Appendix A. Appendix A, column "WIPP WAC and Certification Plan Section," rows 3.4.1 and 3.5.2, contain the titles of applicable procedures that implement the requirements of this section.

The SPM or designee reviews the analytical data to ensure that chemical constituents in the waste are allowable in accordance with the Chemical Lists and that flammable VOCs in the headspace of the payload containers are less than $500 \mathrm{ppm}$. At the discretion of the SPM, additional sampling of the waste stream from which nonconforming containers originated will be performed to determine whether the container is anomalous or is representative of the entire waste stream.

\subsection{CHEMICAL COMPATIBILITY}

\subsubsection{Requirements}

Chemical compatibility of a waste with its packaging ensures that chemical processes will not occur that might pose a threat to the safe transport of a payload in the TRUPACT-II. A chemical compatibility study is specifically required to determine the following:

- Chemical compatibility of the waste form within each individual payload container 
- Chemical compatibility between contents of payload containers during hypothetical accident conditions

- Chemical compatibility of waste forms within the TRUPACT-II inner containment vessel (ICV)

- Chemical compatibility of the waste form with the TRUPACT-II O-ring seals

Chemical compatibility is evaluated in accordance with $A$ Method for Determining the Compatibility of Hazardous Wastes (EPA-600/2-80-076)(EPA 1980). Any incompatibilities between the payload and the package must be evaluated separately if not covered by the EPA method.

\subsubsection{Compliance and Verification}

Program personnel ensure compliance with the chemical compatibility requirements based on acceptable knowledge and analytical data. The TCO verifies chemical compatibility by comparing payload container inventory with approved TRUCON codes using Tables 5-1 through 5-6 of the TRAMPAC. Chemicals and materials are restricted according to the TRUPACT-II Chemical Lists (Attachment B-1 of the TRUPACT-II SARP). If necessary, Program personnel repackage CH TRU waste containers.

Refer to Appendix A, column "WIPP WAC and Certification Plan Section," row 3.4.3, which contains the titles of applicable procedures that implement the requirements of this section.

\subsection{GAS DISTRIBUTION AND PRESSURE BUILDUP}

\subsubsection{Requirements}

Gas generation and pressure buildup during transport of CH TRU wastes in the TRUPACTII payload are restricted to the following limits:

- The gases generated in the payload must be controlled to prevent the occurrence of potentially flammable concentrations of gases within the payload confinement layers and the void volume of the ICV cavity. Specifically, hydrogen concentrations within the payload confinement layers are limited to five percent by volume during a maximum 60 day shipping period.

- The gases generated in the payload and released into the ICV cavity must be controlled to maintain the pressure within the TRUPACT-II ICV cavity below the acceptable design package limit of $50 \mathrm{psig}$.

\subsubsection{Compliance and Verification}

Program personnel ensure compliance with the TRUPACT-II gas generation and pressure buildup requirements by controlling other parameters, as follows:

- Restricting and verifying the chemicals and materials present within each waste type 
- Limiting the maximum number of internal layers of confinement within each payload container

- Ensuring that tilters in payload containers meet requirements

- Limiting the allowable decay heat within each payload container

In this Certification Plan, chemical properties are discussed in Section 4.3; payload container type and contents configuration are discussed in Section 4.6; and decay heat is discussed in Section 4.8. Refer to Appendix A, column "WIPP WAC and Certitication Plan Section," rows 3.2.6, 3.4.1, $3.5 .1,3.5 .2$, and 3.5 .6 , which contain the titles of applicable procedures that implement the requirements of this section.

\subsection{PAYLOAD CONTAINER AND CONTENTS CONFIGURATION}

Requirements specific to the payload container and the configuration of its contents (e.g., liners) are based on the following:

- Payload container and overpacking configuration

- Payload container filters

- Rigid liners

- Inner confinement layers

- Venting and aspiration

The following sections describe specific requirements in these areas.

\subsubsection{Payload Container and Overpacking Configuration}

\subsubsection{Requirements}

The payload container for each TRUPACT-II shipment must be a 55-gal. drum, an SWB, or a TDOP. Each payload container must meet the applicable requirements of Appendix 1.3.3 of the TRUPACT-II SARP. In addition to meeting these specifications at the time of procurement, the integrity of each payload container must be inspected prior to transport. Drums that appear by visual inspection to be corroding or are determined to have a wall thickness less than what is allowable per container specifications must be overpacked in an SWB or repacked into an approved 55-gal. drum.

In addition to the above specifications, payload containers and overpacking configurations must conform to the shipping category designations shown in Table 4-2 and to applicable TRUCON code descriptions provided in the TRUCON. Only certified and categorized payload containers will be overpacked in the TDOP.

\subsubsection{Compliance and Verification}

TRU waste is packaged in accordance with procedures that specify the types of containers used for packaging TRU waste for shipment to WIPP, the filters used on the containers, the use of both rigid liners and inner bags, and venting and aspiration processes. Program personnel review container procurement and inspection records to document that waste containers meet the 
requirements of Appendix 1.3.3 of the TRUPACT-II SARP. Program personnel inspect and verify the integrity of new waste containers (prior to placing waste in them) and of drums in RCRA-compliant storage areas as part of the Hanford Site RCRA inspection program. Drums retrieved from buried storage will be inspected pursuant to independent work plans. Nonconforming containers are overpacked or repackaged in accordance with Transuranic Waste Repackaging, Visual Examination, and Sampling (WMH-400, Section 7.1.3). The TCO verifies that the containers have been inspected and verifies shipping category designation and TRUCON code assignment as indicated in 4.1.1.2 and 4.1.2.2, respectively.

Refer to Appendix A, column "WIPP WAC and Certification Plan Section," row 3.2.1, which contains the titles of applicable procedures that implement the requirements of this section.

\subsubsection{Payload Container Filters}

\subsubsection{Requirements}

Each payload container (except dunnage containers) to be transported in the TRUPACT-II must have one or more filter vents. Appendix 1.3.5 of the TRUPACT-II SARP specifies the flow and hydrogen diffusion requirements for these filters. The minimum number of filter vents shall be one for a heat-sealed plastic bag, one for a drum, one for a pipe container overpacked in a drum, two for an SWB, two for a bin overpacked in an SWB, and nine for a TDOP. All filters installed in drums, SWBs, and TDOPs must meet the specifications in Sections 2.0, 3.0, and 5.0, respectively, of Appendix 1.3 .5 of the TRUPACT-II SARP. Dunnage containers shall have open vent ports (i.e., not filtered or plugged).

\subsubsection{Compliance and Verification}

Waste storage personnel visually verify that filter vents, if present, have been installed properly. If filter vents are not installed, Program personnel procure filter vents that meet specifications and install the correct number of filter vents. The TCO verifies and records this information on the PCTCD in accordance with Receive and Load TRUPACT Containers (WRP1-OP-0521). When a payload container does not meet the payload container filter requirements, an NCR is initiated. Nonconforming waste containers are repackaged in accordance with Transuranic Waste Repackaging, Visual Examination, and Sampling (WMH-400, Section 7.1.3).

Refer to Appendix A, column "WIPP WAC and Certification Plan Section," row 3.2.6, which contains the titles of applicable procedures that implement the requirements of this section.

\subsubsection{Rigid Liners}

\subsubsection{Requirements}

A rigid liner, if present in a payload container, must be punctured (with a $\geq 0.3$-in.diameter hole) or filtered before the container can be transported in a TRUPACT-II. Specifications are provided in Appendix 1.3.3 of the TRUPACT-II SARP. 


\subsubsection{Compliance and Verification}

Program personnel use radiography, visual examination, or acceptable knowledge information to verify that the rigid liner, if present, has been punctured or fitted with a filter vent. When a payload container is found that does not meet the rigid liner requirements, the container is repackaged.

Refer to Appendix A, column "WIPP WAC and Certification Plan Section," row 3.5.6, which contains the titles of applicable procedures that implement the requirements of this section.

\subsubsection{Inner Confinement Layers \\ 4.6.4.1 Requirements}

The inner layers of confinement around the waste material in the payload containers must be plastic bags and/or metal cans meeting the specifications for closure outlined in Appendix 1.3.6 of the TRUPACT-II SARP. Waste may also be placed in containers with no additional inner layers of confinement. Unfiltered bags must be closed with either a twist-and-tape closure or a fold-and-tape closure. At least one filter must be installed on each heat-sealed plastic bag. For waste within a given TRUCON code, the maximum number of layers of bags is specified in the TRUCON. Table 4-3 lists the maximum number of payload container inner bags, liner bags, and total bags allowed for each shipping category.

\subsubsection{Compliance and Verification}

Program personnel review acceptable knowledge information to determine the number of inner liners and the method of inner liner closure from records of the waste management techniques in use at the time the waste was packaged. Radiography operators and visual examination personnel verify this information and document the following:

- Inner liner configuration corresponds to the shipping category indicated on the payload container and on the acceptable knowledge documentation

- Inner liners are closed using one of the approved methods (i.e., fold-and-tape, twist-andtape, or heat-sealed with a minimum of one filter vent)

These activities are conducted in accordance with radiography and visual examination procedures listed in Appendix A. A payload container rejected for noncompliance with the inner confinement layers requirements is repackaged to a compliant configuration, if required. Refer to Appendix A, column "WIPP WAC and Certification Plan Section," row 3.5.6, which contains the titles of applicable procedures that implement the requirements of this section.

\subsubsection{Venting and Aspiration}

\subsubsection{Requirements}

When filters are added to unvented payload containers of waste, the payload containers must be aspirated for a sufficient period of time to equilibrate gases that may have accumulated in the closed containers prior to transport. The procedures to be followed for aspiration and determination of 


\section{HNF-2600 Revision 0}

Table 4-3. Approved Payload Configurations for TRUPACT-II Shipments.

\begin{tabular}{|c|c|c|c|}
\hline $\begin{array}{l}\text { Payload Shipping } \\
\text { Category }^{\mathrm{a}}\end{array}$ & $\begin{array}{l}\text { Number of } \\
\text { Inner Bags }\end{array}$ & $\begin{array}{l}\text { Number of } \\
\text { Liner Bags }\end{array}$ & $\begin{array}{c}\text { Total Number } \\
\text { of Bags }\end{array}$ \\
\hline I. $1 \times 0$ & 0 & 0 & 0 \\
\hline I. $1 X 1$ & 0 & 1 & 1 \\
\hline I. $1 \mathrm{X} 2$ & 0 & 2 & 2 \\
\hline I. $1 \mathrm{X} 3$ & 2 & 1 & 3 \\
\hline I. $2 \times 0$ & 0 & 0 & 0 \\
\hline I. $2 \times 1$ & 0 & 1 & 1 \\
\hline I. $2 \times 2$ & 0 & 2 & 2 \\
\hline I. $2 \times 3$ & 2 & 1 & 3 \\
\hline I. $2 \times 4$ & 3 & 1 & 4 \\
\hline I. $3 \times 0$ & 0 & 0 & 0 \\
\hline $1.3 \times 1$ & 0 & 1 & 1 \\
\hline I. $3 X 2$ & 0 & 2 & 2 \\
\hline I. $3 \times 3$ & 2 & 1 & 3 \\
\hline I. $3 \times 4$ & 3 & 1 & 4 \\
\hline II. 1 X0 & 0 & 0 & 0 \\
\hline II. $1 \mathrm{X} 1$ & 0 & 1 & 1 \\
\hline II. $1 \times 2$ & 1 & 1 & 2 \\
\hline II. $1 X 2 a$ & 0 & 2 & 2 \\
\hline II. $1 \mathrm{X} 3$ & 2 & 1 & 3 \\
\hline Il. $1 \times 4$ & 3 & 1 & 4 \\
\hline II. $1 X 5$ & 4 & 1 & 5 \\
\hline II. 1 X6 & 5 & 1 & 6 \\
\hline II. $2 \mathrm{XM}$ & $\mathrm{N} / \mathrm{A}$ & N/A & N/A \\
\hline IIl. $1 \mathrm{X} 0$ & 0 & 0 & 0 \\
\hline III. 1X1 & 0 & 1 & 1 \\
\hline III. $1 \mathrm{X} 2$ & 1 & 1 & 2 \\
\hline III. $1 X 2 a$ & 0 & 2 & 2 \\
\hline III. $1 \times 3$ & 2 & 1 & 3 \\
\hline III. $1 \mathrm{X} 4$ & 3 & 1 & 4 \\
\hline III. 1 X5 & 4 & 1 & 5 \\
\hline III. $1 \times 6$ & 5 & 1 & 6 \\
\hline IV.1X0T & 0 & 0 & 0 \\
\hline IV.1X1T & 0 & 1 & 1 \\
\hline IV. $1 \mathrm{X} 2 \mathrm{~T}$ & 0 & 2 & 2 \\
\hline IV.1X3T & 2 & 1 & 3 \\
\hline
\end{tabular}

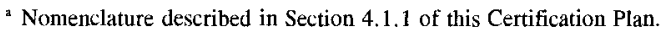

b An inner bag is any plastic bag containing waste with the proper bag closure method, as described in Section 4.6.4.1.

' Liner bag is a drum liner made of polyethylene (PE) or polyvinyl chloride (PVC) with a nominal thickness between 5 and 15 millimeters and having a surface area of at least 1 to $6 \mathrm{~m}^{2}$.

Source: Table 5B, TRUCON (Revision 10). 
aspiration time are presented in Appendix 3.6.11 of the TRUPACT-II SARP. The following three options are provided for showing compliance with aspiration requirements, any one of which may be implemented:

- Option 1 - Aspiration Time Based on Date of Drum Closure: This option determines aspiration time based on the closure date of the payload container and the TRUCON code. This method does not require sampling of headspace gases.

- Option 2 - Headspace Gas Sampling at the Time of Venting: This option determines aspiration time based on the measured concentration of hydrogen in the headspace of the drum (between the drum lid and the rigid liner) at the time of venting.

- Option 3 - Headspace Gas Sampling During Aspiration: This option utilizes the measured headspace concentration of hydrogen two or more weeks after venting to determine aspiration time.

\subsubsection{Compliance and Verification}

Program personnel ensure that all containers are properly vented or repackage CH TRU waste into vented containers. Unvented containers will be allowed to aspirate for a period of time determined using one of the options presented in Section 8.1 .3 of the TRAMPAC and described in Section 4.6.5.1 requirements. The TCO enters the aspiration option used and the information required to compute the aspiration time on the PCTCD.

Refer to Appendix A, column "WIPP WAC and Certification Plan Section," row 3.5.4, which contains the titles of applicable procedures that implement the requirements of this section.

\subsection{ISOTOPIC INVENTORY AND FISSILE CONTENT}

\subsubsection{Requirements}

There are two allowable methods for determining isotopic composition. Mass spectrometry (MS) is a primary method for determining radioisotopic composition of plutonium product material. Isotopic composition for gamma-emitting radionuclides is determined by gamma ray pulse height analysis. When MS is used to determine isotopic composition, the analysis must be performed in accordance with American Society for Testing and Materials (ASTM) methods. Sites that produce or utilize special (non-plutonium) TRU radionuclides have more variability in the isotopic composition of individual payload containers.

The quantity of the radionuclides in each payload container shall be estimated by either a direct measurement of the individual payload container, summation of assay results from individual packages in a payload container, or by direct measurement on a representative sample of a waste stream. The measured quantity of radiation is used to calculate the quantity of other radionuclides and the total quantity of Pu-239 FGE.

The isotopic inventory for each payload container shall include the identity, total quantity, and measurement error for all radionuclides in the waste container. In addition, the total fissile loading in Pu-239 FGE and its measurement error must be determined for each payload container. 
There are two limits for Pu-239 FGE: one for individual payload containers and one for TRUPACTII payloads.

In accordance with the TRAMPAC, Section 9.4.2, a payload container is acceptable for transport in a TRUPACT-II only if the Pu-239 FGE plus two times the error is below $200 \mathrm{~g}$ per drum, $200 \mathrm{~g}$ per pipe overpack, $325 \mathrm{~g}$ per SWB, or $325 \mathrm{~g}$ per TDOP.

The Pu-239 FGE for each payload container is summed to compute the total measured Pu239 FGE for the proposed TRUPACT-II payload. The total Pu-239 FGE error is the square root of the sum of the squares of the individual Pu-239 FGE errors. The total shipment Pu-239 FGE (measured value plus two times the total error) is compared to the TRUPACT-II limit for Pu-239 FGE. The Pu-239 FGE limit for a TRUPACT-II with a payload of 14 55-gal. drums, 2 SWBs, or 1 TDOP is $325 \mathrm{~g}$. The Pu-239 FGE limit for a TRUPACT-II with a payload of 14 pipe overpacks is $2,800 \mathrm{~g}$.

\subsubsection{Compliance and Verification}

NDA personnel obtain information on the isotopic composition of the waste from radiological data provided by waste generators in the acceptable knowledge record and through radioassay of the filled payload container, following Transuranic Waste Certification - Imaging Passive/Active Neutron Assay Operation (WRP1-OP-0905) and Transuranic Waste Certification Gamma Energy Assay Operations (WRP1-OP-0906). Radioassay equipment is qualified in accordance with PDP requirements.

NDA personnel compute the container Pu-239 FGE and container Pu-239 FGE error manually or using a computational algorithm. Software is designed and maintained in accordance with TRU Software Quality Assurance (WMH-400, Section 6.1.1). Individual radionuclide mass quantities and errors are converted to Pu-239 FGE by multiplying the mass values (g) by Pu-239 FGE conversion factors (FGE/g) listed in Table 10.1 of the TRAMPAC, Section 10.1. The container Pu239 FGE is determined by summing the Pu-239 FGE for each radionuclide in the container. The container Pu-239 FGE error is determined by taking the square root of the sum of the squares of the individual Pu-239 FGE errors.

The TCO verities the container FGE data and records them on the PCTCD in accordance with Transuranic Waste Transportation and Disposal Certification (WMH-400, Section 7.1.8). The TCO sums the container Pu-239 FGE and two times the container Pu-239 FGE error and compares the result to the limits of 200 FGE per drum and 325 FGE per SWB. If the container does not meet the criterion, Program personnel repackage it in accordance with TRU Waste Certification - TRU Sorting Glovebox Operation (WRP1-OP-0725).

To assess compliance with the payload Pu-239 FGE requirements, the TCO computes the payload Pu-239 FGE and the payload Pu-239 FGE error. The payload Pu-239 FGE is computed as the sum of the container Pu-239 FGE values for all containers in the proposed payload. The payload Pu-239 FGE error is computed by taking the square root of the sum of the squares of two times the container Pu-239 FGE error values for all containers in the payload. Finally, the payload Pu-239 FGE and the payload Pu-239 FGE error are summed and compared to the limit of $325 \mathrm{Pu}-239 \mathrm{FGE}$. If the payload does not meet the criterion, a different combination of payload containers is identified that meets the TRUPACT-II Pu-239 FGE limit. Once a compliant payload is identified, the TCO records 
HNF-2600 Revision 0

the sum of the payload Pu-239 FGE and payload Pu-239 FGE error on the PATCD in accordance with Transuranic Waste Transportation and Disposal Certification (WMH-400, Section 7.1.8). 
The SQAO (or designee) reviews the isotopic inventory information and verifies the calculation of the Pu-239 FGE. Any payload container found to have incorrect or incomplete information is identified for reassay or other means of resolution.

Refer to Appendix A, column "WIPP WAC and Certification Plan Section," row 3.3.1, which contains the titles of applicable procedures that implement the requirements of this section.

\subsection{DECAY HEAT}

\subsubsection{Requirements}

There are two limits for decay heat:

- A container in a given shipping category is transported in a TRUPACT-II only if the calculated decay heat plus error is below the limits for that shipping category or if the container meets the test requirements specified in the "TRUPACT-II Gas Generation Test Plan to Qualify Test Category Waste for Shipment in the TRUPACT-II" (Attachment 2.0 of TRUPACT-II SARP).

- The total shipment decay heat value (calculated value plus total error) must be less than the TRUPACT-II limit for decay heat. Only those payloads that meet the decay heat limit may be transported in a TRUPACT-II.

\subsubsection{Compliance and Verification}

NDA personnel compute the container decay heat and container decay heat error manually or using a computational algorithm. Software is designed and maintained in accordance with $T R U$ Software Quality Assurance (WMH-400, Section 6.1.1). Individual radionuclide mass quantities and errors are converted to decay heat by multiplying the mass values ( $\mathrm{g}$ ) by decay heat conversion factors $(\mathrm{w} / \mathrm{g}$ ). Table 10.1 in the TRAMPAC lists Pu-239 FGE, decay heat, and specific activity for many radionuclides. The container decay heat is computed by summing the decay heat for all radionuclides in the container. The container decay heat error is computed by taking the square root of the sum of the squares of the decay heat errors for individual radionuclides.

The TCO sums the container decay heat and container decay heat error and compares the result to the limit for individual containers for the applicable shipping category. The TCO verifies the container decay heat data and records it on the PCTCD (described in Section 4.11). If the container does not meet the criterion, it falls into the test category and is tested according to the "TRUPACT-II Gas Generation Test Plan to Qualify Test Category Waste for Shipment in the TRUPACT-II" (Attachment 2.0 of the TRUPACT-II SARP). If the container fails to qualify for transportation, Program personnel repackage it.

To assess compliance with the payload decay heat requirements, the TCO computes the payload decay heat and payload decay heat error. The payload decay heat is computed as the sum of the container decay heat values for all containers in the proposed payload. The payload decay heat error is computed by taking the square root of the sum of the squares of the container decay heat error values for all containers in the payload. Finally, the payload decay heat and payload decay heat error are summed and compared to the limit for the applicable shipping category. If the payload does 
not meet the criterion, a different combination of payload containers is identified that meets the TRUPACT-II decay heat limit. Once a compliant payload is identified, the TCO records the sum of the payload decay heat and payload decay heat error on the PATCD.

Refer to Appendix A, column "WIPP WAC and Certification Plan Section," row 3.5.1, which contains the titles of applicable procedures that implement the requirements of this section.

\subsection{WEIGHT AND CENTER OF GRAVITY}

\subsubsection{Requirements}

The TRUPACT-II SARP restricts the weight of individual payload containers, the payload assembly, loaded TRUPACT-IIs, and on the center of gravity of each payload assembly. The weight limits are as follows:

- 1,000 lbs per drum (for DOT Specification $17 \mathrm{C} / 17 \mathrm{H}$ )

- 700-959 lbs per drum (depending on applicable UN specification - See Table 3-2)

- 1,450 lbs per drum overpacked in an SWB

- 4,000 lbs per SWB

- 6,450 lbs per TDOP

- 328 lbs per 6-in. pipe overpack

- 547 lbs per 12-in. pipe overpack

- 7,265 lbs per payload assembly of 14 drums (including pallet, guide tubes, slip sheets, and reinforcing plates)

- 7,265 lbs per payload assembly of two SWBs

- 19,250 lbs per loaded TRUPACT-II

The center of gravity requirements are as follows:

- The total weight of the top seven drums or SWB must be less than or equal to the total weight of the bottom seven drums or SWB.

- The total weight of the top five drums in a TDOP must be less than or equal to the total weight of the bottom five drums.

The weight of each payload container must be measured and recorded in the PCTCD for individual containers, along with an estimate of the error in the weight (described in Section 4.11). The weight and error of the total TRUPACT-II payload is calculated and reported in the PATCD (described in Section 4.11). 


\subsubsection{Compliance and Verification}

Loading personnel weigh individual payload containers in accordance with Move Waste Drums Throughout the WRAP Facility (WRP1-OP-0503) to ensure that payload containers do not exceed maximum allowable or manufacturer certification weights. Loading personnel calibrate and maintain the scale (to \pm 1 percent) in accordance with National Institute of Standards and Technology (NIST) (formerly the National Bureau of Standards) Handbook 44 (NIST 1988), calculate the error, and record the calibration results. If the waste container meets applicable weight limits, loading personnel record the weight of the container for each payload container. The TCO enters this weight information on the PCTCD (described in Section 4.11) as the container is being prepared for certification. If the measured weight of the payload container (including the error) exceeds applicable weight limits, the containers are repackaged and reweighed.

The TRUPACT-II payload weight limit of 7,265 lbs includes a payload of 14 drums and the payload pallet, optional slip sheets, reinforcing plates, guide tubes, and banding material, or a payload of two SWBs and optional nylon strap assemblies, or one TDOP. The total payload weight is obtained either from the weights and associated errors of the individual components or by weighing the complete assembly. Loading personnel ensure compliance with the center-of-gravity requirements by placing the heavier seven-pack of drums or the heavier SWB at the bottom of the TRUPACT-II. The TCO records assembly weight information on the PATCD.

The TCO reviews loading data and the PCTCD to verify compliance with the individual payload container weight requirement and signs the PCTCD. Payload containers that do not comply with weight limits are segregated and repackaged. The TCO reviews the data and information, approves the weight of the total payload, verifies compliance with the TRUPACT-II payload weight and the center-of-gravity requirements, and signs the PATCD (described in Section 4.11). The TCO also verifies that TRUPACT-II trailer loads meet all DOT weight restrictions.

Refer to Appendix A, column "WIPP WAC and Certification Plan Section," row 3.2.2, which contains the titles of applicable procedures that implement the requirements of this section.

\subsection{RADIATION DOSE RATES}

\subsubsection{Requirements}

The external radiation dose rates of individual payload containers and the three loaded TRUPACT-II payloads to be shipped on a trailer must be less than or equal to $200 \mathrm{mrem} / \mathrm{hr}$ at the surface and $10 \mathrm{mrem} / \mathrm{hr}$ at a $2-\mathrm{m}$ distance, as specified in the TRUPACT-II SARP. The radiation dose rates for the TRUPACT-II must also comply with 10 CFR $\$ 71.47$.

Occasionally, drums of CH TRU waste that meet the surface dose radiation limits require shielding to meet DOE site requirements. The radiation levels at the surface and at a $2-\mathrm{m}$ distance from the unshielded payload container are measured to ensure compliance with the $200 \mathrm{mrem} / \mathrm{hr}$ and $10 \mathrm{mrem} / \mathrm{hr}$ limits, respectively. If the measured radiation levels are below the specified levels but do not meet site as-low-as-reasonably-achievable criteria, shielding may be added to the drum. Drums that exceed the $200 \mathrm{mrem} / \mathrm{hr}$ surface reading or $10 \mathrm{mrem} / \mathrm{hr}$ at $2 \mathrm{~m}$ without shielding may not be transported in a TRUPACT-II. 


\subsubsection{Compliance and Verification}

A Hanford Site RCT measures surface dose rates of the individual payload containers in accordance with Release Survey (WRP1-OP-1209) and Radioactive Material Shipment and Receipt Surveys (WRP1-OP-1201) using the beta-gamma and neutron dose rates for each container at the surface and at $2 \mathrm{~m}$ and records the results for each payload container. If the combined beta-gamma and neutron dose rate exceeds $200 \mathrm{mrem} / \mathrm{hr}$ at the surface or $10 \mathrm{mrem} / \mathrm{hr}$ at $2 \mathrm{~m}$ for any container, the container is rejected, marked, and segregated. Corrective action is taken to resolve the noncompliant condition.

The RCT also surveys the loaded TRUPACT-II surface before shipping and records the highest combined gamma and neutron reading on the PATCD. If this reading exceeds $200 \mathrm{mrem} / \mathrm{hr}$ combined gamma and neutron, the TRUPACT-II is rejected from shipment. Additionally, the reading from a TRUPACT-Il at a 2 -m distance from any side of the TRUPACT-II (excluding the top and bottom) is recorded on the PATCD. If this reading exceeds $10 \mathrm{mrem} / \mathrm{hr}$, the TCO rejects the TRUPACT-II from shipment. If the TRUPACT-II is rejected from shipment, corrective action is taken to resolve the noncompliant condition.

After the payload assemblies are loaded into the TRUPACT-II, the RCT surveys the vehicle's driver and passenger space to ensure the dose rate does not exceed $2 \mathrm{mrem} / \mathrm{hr}$. The TCO reviews the radiation dose rates and records the results of the RCT survey of the TRUPACT-II and transport vehicle on the PATCD for the payload assembly. Program personnel submit radiation dose rate measurement reports to the SPM. The TCO verifies compliance with the radiation dose rate requirements by signing the PATCD.

Refer to Appendix A, column "WIPP WAC and Certification Plan Section," row 3.3.3, which contains the titles of applicable procedures that implement the requirements of this section.

\subsection{PAYLOAD ASSEMBLY CRITERIA}

This section describes the procedures that must be followed to assemble a payload approved for transport in the TRUPACT-II in accordance with Section 13.0 of the TRAMPAC. The parameters described in previous sections must be evaluated in accordance with the constraints in Section 1.2.3 of the TRUPACT-II SARP for selection of a payload.

Only waste with content codes described in the TRUCON may be transported in the TRUPACT-II. The TRUCON assigns each content code to a payload shipping category. Shipping categories impose restrictions and requirements on the manner in which a payload can be assembled as follows:

- After all the payload parameters have been quantified and verified, the shipping category must be clearly marked on the payload container to provide a visual verification that the container is authorized for shipment.

- All containers forming a payload within each TRUPACT-II must belong to the same shipping category. The container identification number uniquely identifies the payload container and the content code identifies a shipping category per the TRUCON which is confirmed if all parameter limits are met. This precludes the mixing of different waste 
material types, different payload containers, and different internal packaging configurations. This requirement applies to drums, SWBs, and TDOPs.

- Payload containers qualified for transport in the analytical and test categories cannot be mixed in a TRUPACT-II.

- Transportation parameters of individual payload containers are recorded on the PCTCD. Separate PCTCD forms are used for the analytical payload shipping category and the test payload shipping category. (Examples of these forms are provided in Appendices $C$ and $D$, respectively.) Information on these forms should be available for each payload container, even if the format is not identical to that shown in Appendices C and D (e.g., use of a computer-generated form is acceptable provided all information required by the QAPD is included). A payload container may be certified for transport only if all transportation parameters are in compliance. The TCO verifies compliance before containers are authorized for transport.

- The transportation parameters of every TRUPACT-II shipment are recorded on the PATCD (shown in Appendix E). The information on this form must be available for each payload assembly, even if the format is not identical to that shown in Appendix E (e.g., use of a computer-generated form is acceptable provided all information is included). A TRUPACT-II shipment is authorized only if all the transportation parameters are in compliance. The TCO verifies compliance before a shipment is authorized for transport.

All authorized payloads must meet the requirements set forth in the TRUPACT-II SARP. Data on the parameters for specific payloads are obtained by the methods outlined in this document in accordance with the specific limits of the TRUCON. The following sections describe methods for evaluating the payload container and shipment data against TRUPACT-II limits and restrictions.

\subsubsection{Certification of Individual Payload Containers for Transport in the TRUPACT-II (Analytical Payload Shipping Category)}

\subsubsection{Requirements}

As required by Section 13.3.1 of the TRAMPAC, individual payload containers must be qualified for transport in a TRUPACT-II by verifying that each container meets the requirements and limits for the parameters listed on the PCTCD for the Analytical Payload Shipping Category.

\subsubsection{Compliance and Verification}

The TCO completes a PCTCD for analytical category waste in accordance with Transuranic Waste Transportation and Disposal Certification (WMH-400, Section 7.1.8) to qualify an individual payload container for shipping. The TCO signs and dates the PCTCD after verifying that each container meets the following transportation parameter requirements:

- Container ID and Container Bar Code numbers-identification numbers unique to each container and used to track process data and package history

- Shipping Category-assigned using the corresponding tables in the TRUCON 
- Content Code-acquired either from the data package (preassigned) or by correlating the waste description with the applicable contents code list in the TRUCON

- Decay Heat Limit-when the shipping category is determined, the allowable decay heat for that category is recorded from Tables 1.2.3.3-1 to 1.2.3.3-3 of Section 1.2.3.3 of the TRUPACT-II SARP

- Container Type-obtained by visual inspection

- Certification Site-the location at which transportation takes place (i.e., the generating site for newly generated waste; the generating or storage site for retrievably stored waste)

- WIPP WAC/Transportation Parameters-for each payload container, the following criteria must be met:

- free liquids limited to residual amounts

- non-radioactive pyrophorics are prohibited

- explosives prohibited

- corrosives are prohibited

- pressurized containers are prohibited

- drum liner (if present) is punctured/filtered

- flammable VOCs are limited to not more than $500 \mathrm{ppm}$

- Filter Identification-information obtained by visual inspection includes filter vent identification of both supplier and date of manufacture, lot number, or unique serial number

- Weight-loaded weight of each payload container obtained from the data package

- Decay Heat-obtained from NDA data report (calculated by combining isotopic inventory data and calculated decay heat for each radionuclide in the waste)

- Fissile Mass (FGE)-obtained from NDA data report (calculated by combining isotopic inventory data and $\mathrm{Pu}-239$ FGE for each radionuclide in the waste)

- Container Weight (plus Error)-obtained from the data package (an error is assigned to the container weight in accordance with methods listed in Chapter 8.0 of the TRAMPAC and compared against the limits listed in Section 1.2.3.3 of the TRUPACT-II SARP)

- Decay Heat (plus Error) - obtained from the data package (decay heat plus error is compared against the limits listed in Section 1.2.3 of the TRUPACT-II SARP)

- Fissile Mass (plus two times the Error) - obtained from the data package (an error is assigned to the fissile mass in accordance with methods listed in Chapter 9.0 of the TRAMPAC and compared against the transport limits listed in Section 1.2.3 of the TRUPACT-II SARP)

- Aspiration Method-confirms that the requirements on aspiration time for containers that have been closed (i.e., not vented with an approved filter vent) for a period of time are met, and answers the following questions: 
- identifies the method for determination of the aspiration period

- indicates the period of time the payload container has been unvented (for option 1 only)

- indicates the concentration of hydrogen measured in the headspace (for options 2 and 3)

- indicates the aspiration time for the option chosen and the aspiration table that the value was derived from in the TRUPACT-II SARP

- indicates if the payload container has been vented for the prescribed period of time

- Approved for Transport-The TCO signs and dates the PCTCD certifying that the requirements for the transportation parameters are met.

After the TCO has verified and documented that all parameters are met, loading personnel clearly mark the individual payload containers with the appropriate shipping category designator. Payload containers that do not comply with parameter limits are not qualified for shipment. These containers are segregated and corrective action is taken to resolve the noncompliant condition.

Refer to Appendix A, column "WIPP WAC and Certification Plan Section," rows 3.2.4 and 3.6.3, which contain the titles of applicable procedures that implement the requirements of this section.

\subsubsection{Certification of Individual Payload Containers for Transport in the TRUPACT-II (Test Payload Shipping Category)}

\subsubsection{Requirements}

In accordance with Section 1.3.2 of the TRAMPAC, payload containers assigned to the test category must meet additional criteria for certification (see Appendix D). These criteria evaluations can be made once the "TRUPACT-II Gas Generation Test Plan to Qualify Test Category Waste for Shipment in the TRUPACT-II" has been instituted at the site. The test plan for this program is presented in Attachment 2.0 of the TRAMPAC.

\subsubsection{Compliance and Verification}

With the exception of waste type IV (solidified organics), which currently is test category waste by definition, the Hanford Site will repackage test category waste into an acceptable configuration to qualify as analytical category waste. For type IV waste or test category waste that cannot be repackaged, the Hanford Site will segregate and store this waste until test category requirements are refined by $\mathrm{CAO}$.

Refer to Appendix A, column "WIPP WAC and Certification Plan Section," rows 3.5.1, 3.5 .2 , and 3.6.3, which contain the titles of applicable procedures that implement the requirements of this section. 


\subsubsection{Assembly of a TRUPACT-II Payload}

\subsubsection{Requirements}

In accordance with Section 13.3.3 of the TRAMPAC, certified payload containers of the same type and shipping category shall be assembled into TRUPACT-II payloads. Only one TDOP, 14 drums, two SWBs, or 14 pipe overpacks of a single shipping category can be assembled into a specific payload. Total TRUPACT-II package limits must be met by ensuring the TRUPACT-II SARP restrictions and requirements are met, and by evaluating the data from the individual PCTCDs.

\subsubsection{Compliance and Verification}

The TCO combines data from the individual PCTCDs and completes a PATCD upon verifying the applicable transportation parameters are met. The parameters listed below correspond with data fields on the PATCD:

- Shipment No,--the shipment number of the trailer of TRUPACT-IIs

- TRUPACT-II OCA Body/Lid Nos. - the identification numbers on the TRUPACT-II OCA body and lid

- Payload Shipping Category -all payload containers must be of the same shipping category (verified through visual inspection of the affixed shipping category labels on each payload container)

- Category Decay Heat Limit-when the payload shipping category is assigned, the allowable decay heat limit for that category is recorded from Tables 1.2.3.3-1 to 1.2.3.3-3 of Section 1.2.3.3 of the TRUPACT-II SARP

- Type of Payload--identifies the approved payload configuration (verified by visual inspection)

- Date ICV Closed-identifies the data the inner containment vessel is closed

- Payload Composition-identifies the following container parameters:

- payload container identification number

- weight and error

- decay heat and error

- FGE and error

Weights, decay heats, and FGEs of individual containers are summed for both top and bottom layers of the assembly, and the total error for each parameter is calculated as indicated on the PATCD

- Total Weight (plus error) of payload and package-indicates that the total weight of the payload and package does not exceed limits established in Section 1.2.3 of the

TRUPACT-II SARP; the total error can be determined by weighing the entire payload assembly 
- Bottom Layer (plus error) $\geq$ Top Layer (plus error)-the total weight of the bottom layer of seven drums, seven pipe overpacks, SWB, or five drums in a TDOP must be verified to be greater than or equal to the top layer

- Total Weight (plus error) $\leq 7,265$ lbs-the total weight plus error must be verified to be less than or equal to $7,265 \mathrm{lbs}$

- Total Decay heat (plus error) of all containers-indicates that the total decay heat plus error for all containers comprising the shipment does not exceed limits set in Section 1.2.3 of the TRUPACT-II SARP for the shipping category

- Total Pu-239 FGE (plus error) of all containers-indicates that the calculated total fissile quantity plus two times the error for all containers comprising the shipment does not exceed limits set in Section 1.2.3 of the TRUPACT-II SARP

- TRUPACT-II Dose Rates-indicates that dose rate measurements do not exceed limits set in Section 1.2.3 of the TRUPACT-II SARP

The TCO signs and dates the PATCD upon verifying the TRUPACT-II transportation requirements are met and the payload is certified for transport. When a complete payload of an acceptable configuration (i.e., 1 TDOP, 2 SWBs, 14 55-gal. drums, or 14 pipe overpacks) of a single shipping category is assembled, loading personnel load the TRUPACT-II in accordance with Assemble and Stretch Wrap TRUPACT Payload (WRP1-OP-0522).

Refer to Appendix A, column "WIPP WAC and Certification Plan Section," rows 3.2.1 and 3.6.3, which contain the titles of applicable procedures that implement the requirements of this section.

\subsubsection{Use of Dunnage Containers}

\subsubsection{Requirements}

In accordance with Section 13.4 of the TRAMPAC, dunnage is not required in TRUPACTII shipments when the 14-drum or two-SWB configuration is used. However, dunnage must be used to complete one of the above configurations if fewer payload containers than meet all payload container and transportation requirements are available per shipment.

\subsubsection{Compliance}

Loading personnel can use empty 55-gal. drums or SWBs as dunnage. Dunnage drums may be assembled into a seven-pack of only dunnage drums, or may be assembled into a seven-pack with drums of waste that meet all applicable requirements. In the latter case, the dunnage drum(s) are labeled with a unique package identification number like the waste drums. All dunnage containers are labeled "EMPTY" or "DUNNAGE." Loading personnel ensure that dunnage containers have open vent ports (i.e., vent ports shall be unplugged of filtered). Shoring, including empty drums, is provided as necessary inside a TDOP. The TCO ensures that dunnage drums meet all applicable requirements following the procedures in Assemble and Stretch Wrap TRUPACT Payload (WRP1-OP0522). 
Refer to Appendix A, column "WIPP WAC and Certification Plan Section," row 3.2.5, which contains the titles of applicable procedures that implement the requirements of this section. 


\subsection{QUALITY ASSURANCE PLAN}

The WIPP WAC requires each site to develop and implement QA plans for TRU waste characterization, certification, and packaging. QA plans are submitted to CAO for approval before TRU wastes are formally characterized, certified, and transported to WIPP. The TRAMPAC requires payload compliance for shipment in a TRUPACT-II be certified under a QA program that is equivalent to 10 CFR Part 71, Subpart H. The QAPD establishes QA program requirements for all programs, projects, and activities sponsored by CAO. The QA plan associated with the Certification Plan must apply QAPD requirements. The QAPP supplements the QAPD requirements and establishes QA requirements for TRU waste characterization. QAPP requirements are implemented by the QAPjP and associated program- and operational-level procedures, including the QA/QC elements for analytical laboratories and sampling and testing facilities.

This QA plan implements the QA requirements for certification established in the QAPD, 10 CFR $\$ 830.120$, and TRAMPAC. Table 5-1 provides a cross-reference of applicable QA requirements. The Hanford Transuranic Waste Packaging Quality Assurance Plan (Hanford 1998d) implements DOT and NRC requirements applicable to the use, maintenance, and control of packages used to transport TRU waste to WIPP. QA/QC activities applicable to loading the TRUPACT-II comply with TRUPACT-II Procedures and Maintenance Instructions. The TRUPACT-II is not used without CAO granting authority.

The organization of this QA plan is based on the QAPD and is outlined below:

- Organization and QA Program documents the organizational structure, primary interfaces functional responsibilities, levels of authority, and lines of communication for activities affecting quality, and identifies the activities and items to which the QA program applies.

- Personnel Qualification and Training identifies the Hanford Site qualification and training programs and plans established to ensure personnel are provided training to perform their assignments and maintain job proficiency.

- Quality Improvement describes the processes to detect and prevent conditions adverse to quality, pursue continuous quality improvement, and control and correct nonconforming items.

- Documents and Records describes the processes for preparation, review, approval, issue, use, revision, and control of Program documents and records.

- Work Processes identifies the processes by which work conditions and equipment are controlled to ensure quality.

- Design Control identifies implementing documents that control design processes.

- Procurement identifies the technical and QA requirements for procured items and services.

- Inspection and Testing identifies the processes for inspection and testing. 
HNF-2600 Revision 0

Table 5-1. Cross-Reference of Quality Assurance Requirements.

\begin{tabular}{|c|c|c|}
\hline $\begin{array}{l}\text { QAPD and } \\
\text { QA Plan Section }\end{array}$ & 10 CFR $\$ 830.120$ & TRAMPAC \\
\hline Organization and QA Program & Program & $\begin{array}{l}\text { QA Organization } \\
\text { QA Program }\end{array}$ \\
\hline $\begin{array}{l}\text { Personnel Qualification and } \\
\text { Training }\end{array}$ & $\begin{array}{l}\text { Personnel Training and } \\
\text { Qualification }\end{array}$ & QA Program \\
\hline Quality Improvement & Quality Improvement & $\begin{array}{l}\text { Corrective Action } \\
\text { Nonconforming Materials, Parts, or } \\
\text { Components }\end{array}$ \\
\hline $\begin{array}{l}\text { Documents } \\
\text { Records }\end{array}$ & Documents and Records & $\begin{array}{l}\text { Document Control } \\
\text { QA Records }\end{array}$ \\
\hline Work Processes & Work Processes & $\begin{array}{l}\text { Instructions, Procedures, and Drawings } \\
\text { Identification and Control of Materials, } \\
\text { Parts, and Components } \\
\text { Control of Special Processes }\end{array}$ \\
\hline Procurement & Procurement & $\begin{array}{l}\text { Procurement Document Control } \\
\text { Control of Purchased Material, } \\
\text { Equipment, } \\
\text { and Services }\end{array}$ \\
\hline Inspection and Testing & $\begin{array}{l}\text { Work Process and Acceptance } \\
\text { Testing }\end{array}$ & $\begin{array}{l}\text { Internal Inspection } \\
\text { Test Control } \\
\text { Control of Measuring and Test } \\
\text { Equipment } \\
\text { Inspection, Test, and Operating Status }\end{array}$ \\
\hline Assessment Requirements & $\begin{array}{l}\text { Management Assessment } \\
\text { Independent Assessment }\end{array}$ & Audits \\
\hline Sample Control Requirements & Work Processes & Not applicable \\
\hline $\begin{array}{l}\text { Scientific Investigation } \\
\text { Requirements }\end{array}$ & $\begin{array}{l}\text { Work Processes } \\
\text { Design }\end{array}$ & $\begin{array}{l}\text { Identification and Control of Materials, } \\
\text { Parts, and Components }\end{array}$ \\
\hline Software Requirements & Not applicable & Not applicable \\
\hline
\end{tabular}


- Assessment Requirements describes the requirements for conducting management and independent assessments to measure management effectiveness, item quality, and process effectiveness and to promote improvement.

- Sample Control Requirements identifies the requirements for the control of waste samples, including identification, handling, storing, shipping, and archiving.

- Scientific Investigation Requirements describes the requirements for defining, controlling, verifying, and documenting scientific investigations.

- Software Requirements specifies the requirements for developing, procuring, maintaining, and using software.

\subsection{ORGANIZATION AND QA PROGRAM}

This QA program applies to items and activities affecting Program quality. The QA activities are integrated into the Program through reviews, assessments, inspections, and approval and control of records and documents. The Hanford Site has identified the SPM, SQAO, CO, and TCO as responsible for ensuring QA within the Program. The responsibilities of each of these positions, as well as other personnel involved with TRU waste characterization, certification, packaging, and transportation, are summarized in this Certification Plan (Section 2.1) and the QAPJP (Section 1.1)

All personnel involved with TRU waste certification, packaging, and transportation ensure the quality of their activities and products. If work is delegated, the individual making the delegation retains responsibility for the delegated work. Disputes related to QA program requirements will be resolved by the SQAO and cognizant Program personnel.

Figure 1-1 (see Section 1.0) illustrates the hierarchy and interrelationships of QA documents governing the QA program. Quality management documents are audited and/or assessed to ensure they meet Program requirements.

Program personnel plan certification activities and document the planning process. Planning documentation is subject to review by facility managers and subject matter experts. Program planning documentation consists of this Certification Plan, the QAPjP, implementing procedures, QA plans, training plans, and facility and certification process designs. These documents establish performance criteria and methods to measure performance relevant to the Program.

\subsection{PERSONNEL QUALIFICATION AND TRAINING}

Personnel performing work in support of the Program are qualified and trained to ensure that suitable proficiency is achieved and maintained in the performance of their assigned tasks. Records documenting qualifications and completed training programs are maintained and controlled as described in Sections 5.4 and 5.5. 


\subsubsection{Qualification}

Facility managers determine qualification standards for each job category relevant to the Program and ensure that qualifications of Program personnel, including minimum education and experience, have been verified. Waste management program personnel maintain minimum qualifications in accordance with Transuranic Training and Qualification Plan (WMH-400, Section 1.2.1). The SPM assists facility managers in determining which positions relevant to the Program require minimum qualifications. Facility managers ensure that auditable records documenting each key individual's qualifications and certifications are maintained as described in TRU Records Management (WMH-400, Section 1.5.1).

\subsubsection{Training}

The SPM and facility managers ensure that all Program personnel receive indoctrination and training on the scope, purpose, and objectives of the Program and the specific QAOs of the tasks being performed. Personnel receive initial and continuing training requisite with their activities and level of responsibility, as described in Transuranic Training and Qualification Plan (WMH-400, Section 1.2.1).

Training is designed, developed, conducted, and evaluated in accordance with Hanford Site requirements described in TRU Training and Qualification Program (WMH-400, Section 1.2.4). Training programs may include classroom instruction; practical hands-on experience; supervised onthe-job training; self-paced individual study; and written, oral, or practical demonstration of worker competence. Facility managers (or designees) analyze job positions and determine task responsibilities for Program personnel to ensure education, experience, and training is commensurate with minimum requirements specified. Facility managers are responsible for ensuring that auditable records documenting the required training and certification are maintained in accordance with TRU Records Management (WMH-400, Section 1.5.1).

\subsection{QUALITY IMPROVEMENT}

Program personnel continually evaluate and improve program activities. The SQAO ensures that quality improvement in the Program is achieved by identifying and controlling conditions adverse to quality, analyzing trends, reporting and tracking nonconformances, and implementing corrective actions. These quality improvement activities detect and prevent unacceptable quality problems and thereby increase accuracy and reliability, and reduce variability.

A condition adverse to quality is an all-inclusive term used in reference to failures, malfunctions, deficiencies, and nonconforming items and processes. Program personnel report conditions adverse to quality to facility QA officers and/or the SQAO, who ensure that the condition adverse to quality is investigated and that corrective action is taken as described in this section.

Nonconformances are uncontrolled and unapproved deviations from an approved plan, procedure, or expected result. Nonconformances specific to the Program also include documentation or management practices that do not meet the requirements related to waste certification, packaging, and transportation which are identified in the QAPP, WIPP WAC, QAPD, DOE orders, and applicable federal and state regulations. Program personnel are responsible for identifying any condition that affects the program's compliance with these requirements. Audits and assessments may 
often identify systems, processes, products, or services that do not meet performance criteria established in planning documents. Program personnel take prompt action to rectify the situation.

The SQAO, the SPM, facility managers, and facility QA officers have the authority to stop certification activities and/or refuse to accept work products or services (e.g., procured items, documentation, packaging, and waste shipments) that do not conform to Program requirements. The stop work authority is documented and verified through Hanford Site line management concurrence with, and DOE-RL approval of, this Certification Plan. All Hanford Site employees have the responsibility to stop work that poses a clear and imminent danger to the safety and health of employees, subcontractors, or visitors or the environment.

Any individual who identifies a nonconformance prepares an NCR in accordance with TRU Nonconformance Item Reporting and Control (WMH-400, Section 1.3.2). If the safety or quality of the certification process could be compromised by continued use of a nonconforming item, the item is taken out of service and tagged or otherwise identified to prevent reuse or acceptance until the nonconformance is corrected. The facility manager of the facility where the nonconformance is identified ensures that an NCR is initiated and that corrective action is taken to resolve the nonconformance. TRU Corrective Action Management (WMH-400, Section 1.3.1) guides the corrective action process.

If the nonconformance affects Program-related activities, the facility manager (or designee) forwards the NCR to the SQAO. The SQAO is responsible for documenting and tracking Programrelated nonconformances and ensures that corrective action is implemented and resolves the nonconformance. TRU Corrective Action Management (WMH-400, Section 1.3.1) guides the corrective action process. The SQAO ensures dissemination of information that may prevent problems or help improve parallel processes in other waste generator or Program activities, and reevaluates system performance after corrective actions have been implemented. The facility manager provides the resources necessary to accomplish corrective actions.

The SQAO, facility managers, and facility QA officers are jointly responsible for identifying the following:

- Trends in nonconformances

- Root-causes of nonconformances

- Specific, measurable corrective actions to resolve current problems and prevent recurrence

- Personnel responsible for implementing corrective actions

- Schedules for completing corrective actions

\subsection{DOCUMENTS}

Documents that specify quality requirements or establish activities affecting quality are controlled to ensure that accurate and current documents are used. Document control ensures that documents have gone through the designated review and approval process and are distributed to the appropriate personnel.

Program personnel prepare and control documents supporting the quality of the Program in compliance with TRU Document Control (WMH-400, Section 1.4.1). Document control coordinators ensure that documents are developed as prescribed by current procedures; reviewed for adequacy, correctness, and completeness; approved; revised; and distributed to the appropriate personnel. 
Document control coordinators control documents and all revisions developed specifically for the Program, including:

- Certification Plan

- QAPjP

- Transuranic Waste Sampling Plan

- QAPD Procedures Matrix

- Plans and procedures implementing the TRU waste characterization, certification, packaging, and transportation requirements

\subsection{RECORDS}

A QA record is an authenticated record that furnishes evidence of the quality of items and/or activities. The minimum Program records maintained are identified in Table $1-4$ of the QAPjP. QA records are controlled and maintained to certify compliance with requirements, and to reflect completed work. QA records are indexed, classified, controlled, and maintained by records management personnel as described in TRU Records Management (WMH-400, Section 1.5.1).

\subsection{WORK PROCESSES}

The work processes and items supporting and affecting Program quality are controlled through plans and procedures identified in this Certification Plan, the QAPjP, and the QAPD Procedures Matrix. Procedures and plans are developed, reviewed, approved, revised, and distributed in accordance with TRU Document Control (WMH-400, Section 1.4.1). Program technical and QA personnel comply with the applicable technical standards and administrative controls described in procedures, which are reviewed and approved by the SPM (or designee), the SQAO (or designee), and cognizant facility manager. Facility managers ensure personnel perform work following established procedures.

The procedures identified in this Certification Plan, the QAPJP, and the QAPD Procedures Matrix, provide the following information: organizational and individual responsibilities, training and qualification requirements, technical, regulatory, and QA requirements, step-by-step instructions for the process, equipment specifications, methods and criteria for ensuring and verifying the acceptability of equipment and materials used in the process (i.e., calibration and maintenance), the products of the process, and the records generated by the process. Activities highly dependent on process control require more detailed procedures.

Each individual performing the work is responsible for ensuring that work processes are controlled and comply with established criteria. Facility managers are responsible for ensuring that workers have the correct procedures, materials, and training to perform quality work. 


\subsection{PROCUREMENT}

The following procurement documents ensure that items and services procured in support of the Program meet established requirements:

- TRU Procurement Planning (WMH-400, Section 2.3.1)

- TRU Procurement Document Control (WMH-400, Section 2.3.2)

- TRU Control of Purchased Items and Services (WMH-400, Section 2.3.3)

These documents describe control of procured items, services, subcontractors, and suppliers, and describe processes for controlling procurement documents to ensure the following:

- Quality-affecting procurements are performed in accordance with established requirements for evaluation of selected services or equipment

- Review and evaluation of the supplier's QA program are conducted

- Inspections, audits, and/or examinations of items and services are performed upon receipt or completion

\subsection{INSPECTION AND TESTING}

Program personnel routinely test and inspect items and processes and control, calibrate, and maintain equipment to ensure proper operation and data quality. Inspection, testing, and calibration procedures are identified in the QAPjP (Sections 7.0 through 15.0) and the QAPD Procedures Matrix. These procedures and documents address planning, parameters for evaluation, techniques to be used, qualification of inspection and test personnel, hold points, documentation, acceptance criteria, and organizational responsibilities.

\subsection{ASSESSMENT REQUIREMENTS}

The Hanford Site participates in assessments and audits to ensure that the Program is in compliance with applicable requirements. Management assessments are conducted by Hanford Site Program management, and independent assessments by site personnel independent of the Program. $\mathrm{CAO}$ and external regulatory agencies conduct audits and assessments. For example, testing and analytical facilities supporting the Program participate in the PDP, as described in the QAPJP (Section 2.3). The SQAO and facility QA officers track nonconformances identified during audits and assessments, identify corrective actions to resolve them according to TRU Nonconformance Item Reporting and Control (WMH-400, Section 1.3.2) and ensure the resolutions are reported to the SPM, DOE-RL, and CAO as described in the QAPjP (Section 2.0) and this Certification Plan (Section 5.3).

\subsubsection{Management Assessments}

Program managers at all levels periodically assess the performance of their organization to determine the effectiveness of QA Program provisions that enable the organization to comply with requirements of the QAPP, QAPD, WIPP WAC, TRAMPAC, and applicable procedures and documents. Managers evaluate QA Program effectiveness by focusing on the identification and 
resolution of both systemic and management issues and problems, and identifying strengths and weaknesses to facilitate actions to improve quality efficiency and cost-effectiveness. The management assessment should include an introspective evaluation to determine whether the entire integrated management system effectively focuses on meeting strategic goals. Management assessments are conducted as described in TRU Management Assessment (WMH-400, Section 3.1.1). Program managers are responsible for the conduct of these assessments and report at least annually on relevant findings.

\subsubsection{Independent Assessments}

Documented independent assessments are used to measure item service and quality, process adequacy and effectiveness, and to promote improvement. Independent assessments are conducted in accordance with TRU Independent Assessments (WMH-400, Section 3.2.1). Program personnel and facilities are subject to periodic independent assessments performed by teams assembled by the SQAO. Independent assessment teams include one or more qualified assessors, one of whom is also a certified lead auditor. Audit personnel qualifications are addressed in TRU Training and Qualification Plan (WMH-400, Section 1.2.1) and Qualification and Certification of Audit Personnel (WMH-400, Section 1.2.3) and are in accordance with the QAPD.

The SQAO and facility QA officers track assessment results, identified nonconformances, and resulting corrective actions. Facility managers are responsible for carrying out necessary corrective actions.

\subsubsection{Audits}

Facilities participating in the Program are subject to CAO audits. A CAO audit of the Program is conducted before waste is shipped to WIPP and annually thereafter. These audits are the responsibility of the CAO QA manager, who coordinates these audits through the SPM and SQAO. The SQAO ensures that all conditions adverse to quality are resolved and that appropriate corrective actions are implemented in a timely manner. The SQAO develops a schedule, in association with Program facility managers, that details follow-up activities and final resolution of all corrective actions. The SQAO tracks corrective actions to completion and monitors the status of the corrective actions to ensure timely closure of nonconforming conditions.

\subsection{SAMPLE CONTROL REQUIREMENTS}

Program personnel utilize procedures to ensure proper documentation and tracking of sample possession from the time of collection/identification, through handling, preservation, shipment, transfer, analysis, storage, and final disposition. Sample control procedures used by Program personnel are described in Transuranic Waste Sample and Waste Container Management (WMH-400, Section 7.1.7). Program personnel ship samples in compliance with DOT regulations and Program $Q A$ requirements.

\subsection{SCIENTIFIC INVESTIGATION REQUIREMENTS}

The plans and procedures developed and implemented to support the Program define, control, verify, and document the scientific investigations (i.e., planning and data collection activities) related 
to TRU waste management. Scientific investigations supporting the Program are controlled by the QAPjP and include testing, sampling, and analyses, and documenting and validating analytical data. The TRU waste characterization and validation methods are controlled by procedures listed in the QAPJP (Sections 3.0 and 7.0 through 15.0)and the QAPD Procedures Matrix (Section 5.0). These procedures require Program personnel to: (1) document all activities, results, and deviations in scientific notebooks; (2) plan all investigations to ensure collection of useable data; (3) undergo peer review of work; and (4) validate data.

\subsection{SOFTWARE REQUIREMENTS}

TRU Software Quality Assurance (WMH-400, Section 6.1.1) controls the development, procurement, maintenance, use, verification, and validation of software supporting the Program. Software includes computer programs, procedures, rules, and associated documentation and data pertaining to the operation of a computer system. 


\subsection{REFERENCES}

10 CFR Part 71, "Packaging and Transportation of Radioactive Material," Code of Federal Regulations, Washington, D.C., Office of the Federal Register National Archives and Records Administration.

10 CFR Part 830, "Nuclear Safety Management," Code of Federal Regulations, Washington, D.C., Office of the Federal Register National Archives and Records Administration.

10 CFR Part 835, "Occupational Radiation Protection," Code of Federal Regulations, Washington, D.C., Office of the Federal Register National Archives and Records Administration.

40 CFR Part 191, "Environmental Radiation Protection Standards for the Management and Disposal of Spent Nuclear Fuel, High-Level and Transuranic Radioactive Wastes, "Code of Federal Regulations, Washington, D.C., Office of the Federal Register National Archives and Records Administration.

40 CFR Part 194, "Criteria for the Certification and Re-Certification of the Waste Isolation Pilot Plant's Compliance with the 40 CFR Part 191 Disposal Regulations," Code of Federal Regulations, Washington, D.C., Office of the Federal Register National Archives and Records Administration.

40 CFR Part 261, "Identification and Listing of Hazardous Waste," Code of Federal Regulations, Washington, D.C., Office of the Federal Register National Archives and Records Administration.

40 CFR Part 262, "Standards Applicable to Generators of Hazardous Wastes," Code of Federal Regulations, Washington, D.C., Office of the Federal Register National Archives and Records Administration.

40 CFR Part 264, "Standards for Owners and Operators of Hazardous Waste Treatment, Storage, and Disposal Facilities," Code of Federal Regulations, Washington, D.C., Office of the Federal Register National Archives and Records Administration.

40 CFR Part 268, "Land Disposal Restrictions," Code of Federal Regulations, Washington, D.C., Office of the Federal Register National Archives and Records Administration.

40 CFR Part 270, "EPA Administered Permit Programs: The Hazardous Waste Permit Program," Code of Federal Regulations, Washington, D.C., Office of the Federal Register National Archives and Records Administration.

49 CFR Part 172, "Hazardous Materials Table, Special Provisions, Hazardous Materials Communications, Emergency Response Information, and Training Requirements," Code of Federal Regulations, Washington, D.C., Office of the Federal Register National Archives and Records Administration.

49 CFR Part 173, "Shippers-General Requirements for Shipments and Packagings," Code of Federal Regulations, Washington, D.C., Office of the Federal Register National Archives and Records Administration. 
ASME, 1989, Quality Assurance Program Requirements for Nuclear Facilities, ASME NQA-1, 1989 Edition, New York, New York, American Society of Mechanical Engineers.

ASME, 1990, Quality Assurance Program Requirements of Computer Software for Nuclear Facility Applications, ASME NQA-2a-1990, Part 2.7, Addenda to NQA-2, New York, New York, American Society of Mechanical Engineers.

DOD, 1989, Standard Department of Defense Bar Code Symbology, U.S. Department of Defense.

DOE, 1996, TRUPACT-II Content Codes (TRUCON), DOE/WIPP 89-004, Current Revision, Waste Isolation Pilot Plant, Carlsbad, New Mexico, U.S. Department of Energy.

DOE, 1995a, 40 CFR 191 Compliance Certification Application, DOE/CAO-2056, Carlsbad Area Office, Carlsbad, New Mexico, U.S. Department of Energy.

DOE, 1995b, Transuranic Waste Baseline Inventory Report, CAO-95-1121, Current Revision, Carlsbad Area Office, Carlsbad, New Mexico, U.S. Department of Energy.

DOE, 1996a, U.S. Department of Energy-Carlsbad Area Office Quality Assurance Program Document, CAO-94-1012, Current Revision, Carlsbad Area Office, Carlsbad, New Mexico, U.S. Department of Energy.

DOE, 1996b, Transuranic Waste Characterization Quality Assurance Program Plan, CAO-94-1010, Current Revision, Carlsbad Area Office, Carlsbad, New Mexico, U.S. Department of Energy.

DOE, 1996c, Test and Evaluation Document for the U.S. Department of Transportation Specification 7A, Type A Packaging, WHC-EP-0558, U.S. Department of Energy.

DOE, 1996d, Waste Acceptance Criteria for the Waste Isolation Pilot Plant, DOE/WIPP-069, Current Revision, Waste Isolation Pilot Plant, Carlsbad, New Mexico, U.S. Department of Energy.

DOE, 1996e, WIPP RCRA Part B Permit Application, DOE/WIPP-91-005, Current Revision, Waste Isolation Pilot Plant, Carlsbad, New Mexico, U.S. Department of Energy.

DOE, 1997, Carlsbad Area Office Interim Guidance on Ensuring that Waste Qualifies for Disposal at the Waste Isolation Pilot Plant, Current Revision, Carlsbad Area Office, Carlsbad, New Mexico, U.S. Department of Energy.

DOE Order 1324.5B, 1995, Records Management Program, Washington, D.C., U.S. Department of Energy.

DOE Order 5700.6C, 1996, Quality Assurance, Washington, D.C., U.S. Department of Energy.

DOE Order 5820.2A, 1988, Radioactive Waste Management, Washington, D.C., U.S. Department of Energy.

DOE Order 6430.1A, 1989, General Design Criteria, Washington, D.C., U.S. Department of Energy.

EPA, 1980, A Method for Determining the Compatibility of Hazardous Wastes, EPA-600/2-80-076, Washington D.C., U.S. Environmental Protection Agency. 
EPA, 1997, Test Methods for Evaluating Solid Waste, Physical/Chemical Methods, SW-846, Third Edition, Final Update I and Final Update II and III, Office Solid Waste and Emergency Response, Washington, D.C., U.S. Environmental Protection Agency.

Hanford, 1998a, Hanford Site TRU Waste Characterization Quality Assurance Project Plan, Richland, Washington, Waste Management Federal Services of Hanford, Inc.

Hanford, 1998b, Hanford Site TRU Waste Program Quality Assurance Program Document Procedures Matrix, Draft, Richland, Washington, Waste Management Federal Services of Hanford, Inc.

Hanford, 1998c, Hanford Site Transuranic Waste Sampling Plan, Richland, Washington, Waste Management Federal Services of Hanford, Inc.

Hanford, 1998d, Hanford Transuranic Waste Packaging Quality Assurance Plan, Draft, Richland, Washington, Waste Management Federal Services of Hanford, Inc.

Hanford, 1994, Hanford Site Radiological Control Manual (HSRCM-1), Richland, Washington, Waste Management Federal Services of Hanford, Inc.

NIST, 1988, Specifications, Tolerances, and Other Technical Requirements for Weighing and Measuring Devices, Handbook 44, Boulder, Colorado, U.S. Department of Commerce, National Institute of Standards and Technology.

NRC, 1997, Safety Analysis Report for the TRUPACT-II Shipping Package, Docket No. 9218, Current Revision, Washington, D.C., U.S. Nuclear Regulatory Commission.

Waste Isolation Pilot Plant Land Withdrawal Act, Public Law 102-579.

Westinghouse, 1995, Waste Isolation Pilot Plant Safety Analysis Report, DOE/WIPP-95-2065, Carlsbad, New Mexico, Westinghouse Electric Corporation. 


\section{APPENDIX A}

SUMMARY OF CH TRU WASTE ACCEPTANCE CRITERIA, REQUIREMENTS, AND COMPLIANCE AND VERIFICATION DOCUMENTS AND PROCEDURES 
HNF-2600 Revision 0

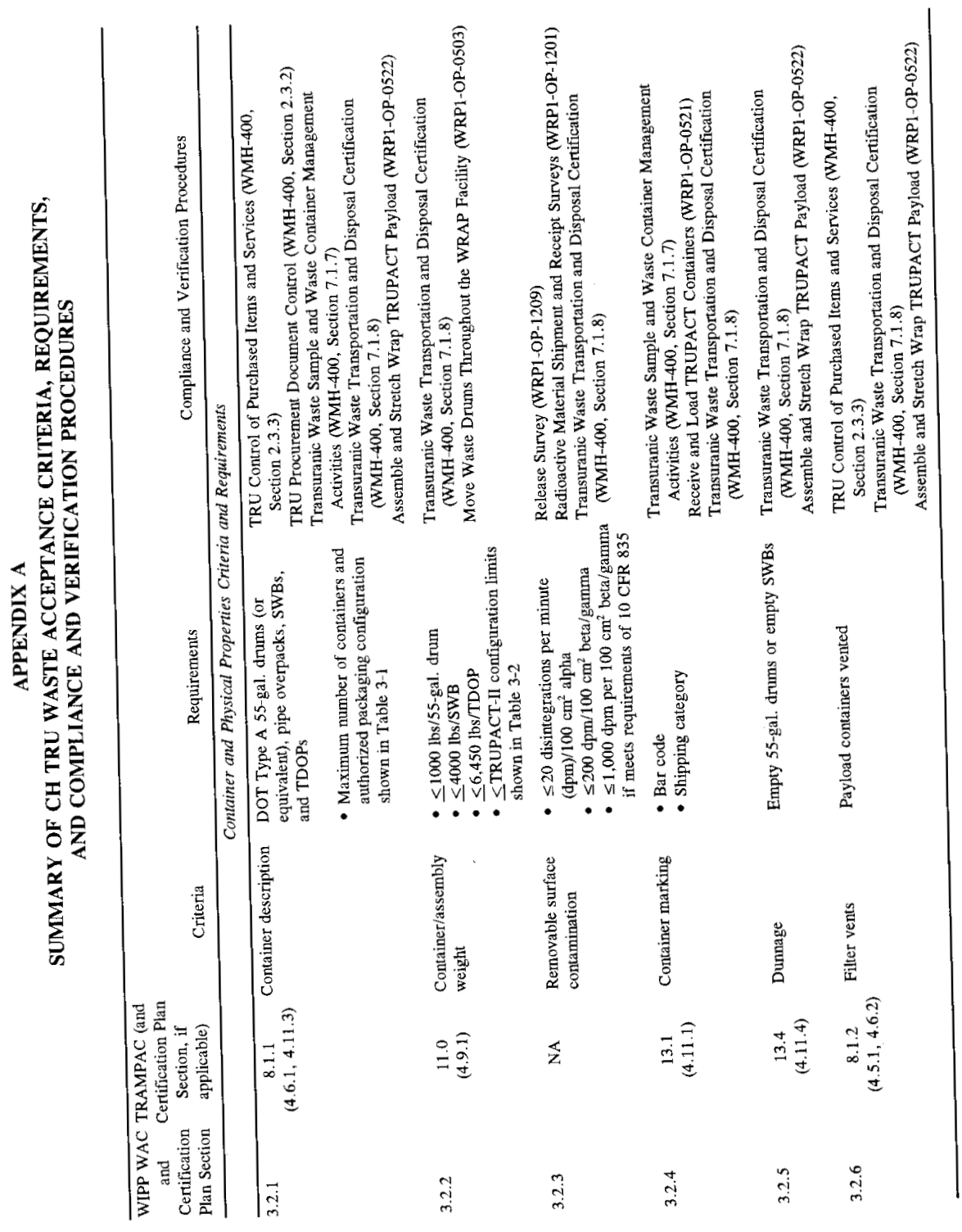


HNF-2600 Revision 0
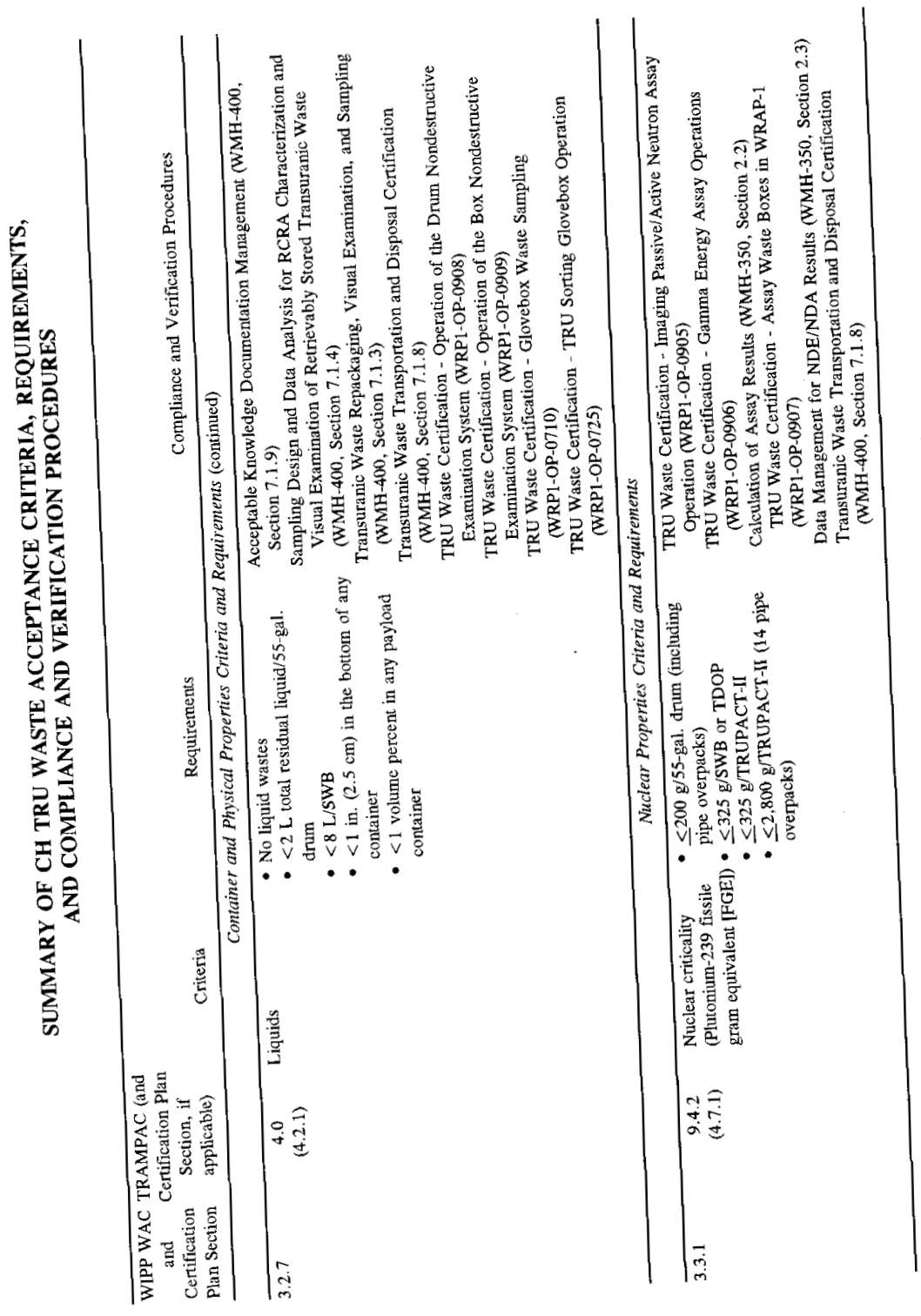
HNF-2600 Revision 0

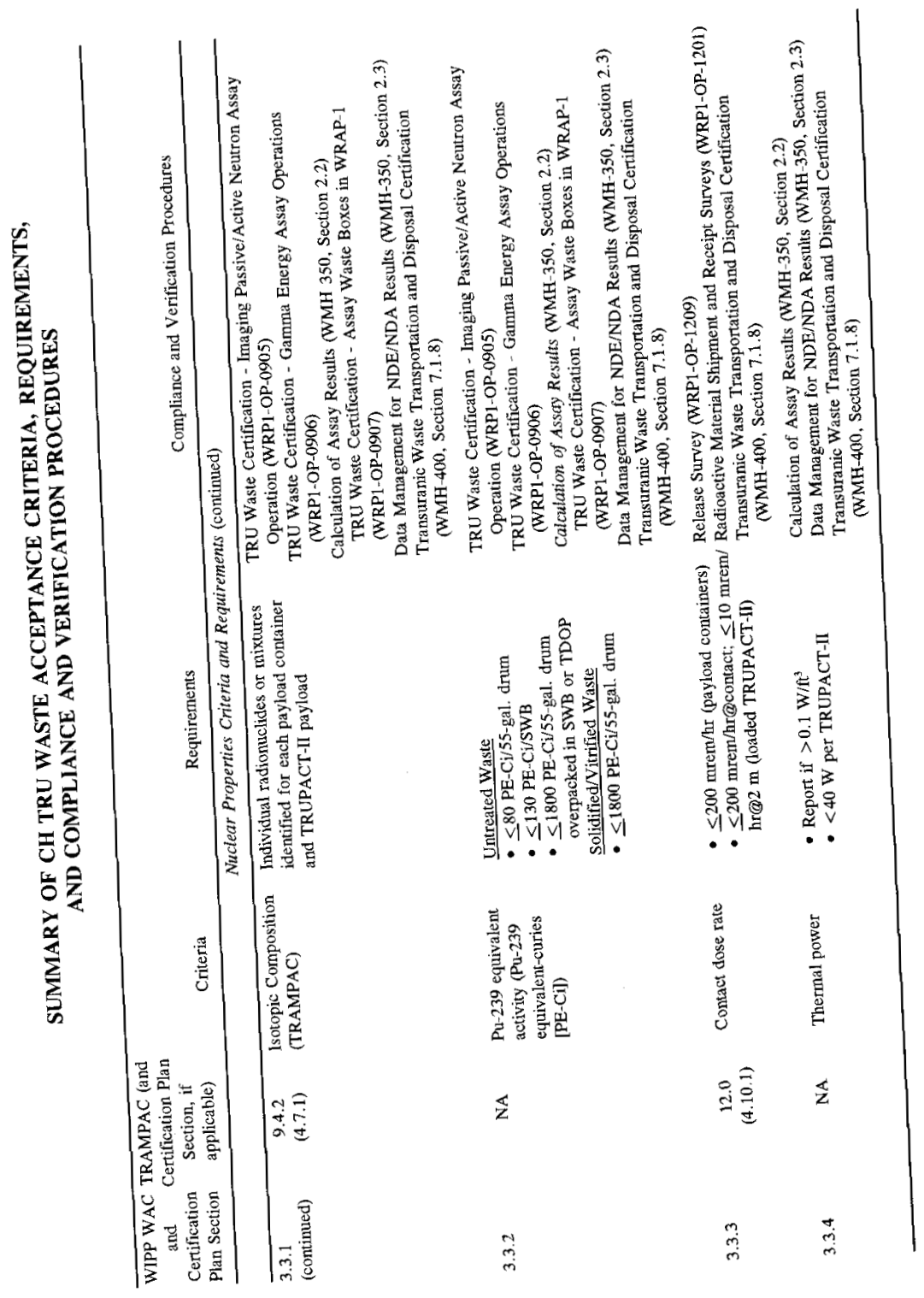

November 10, 1998 
HNF-2600 Revision 0

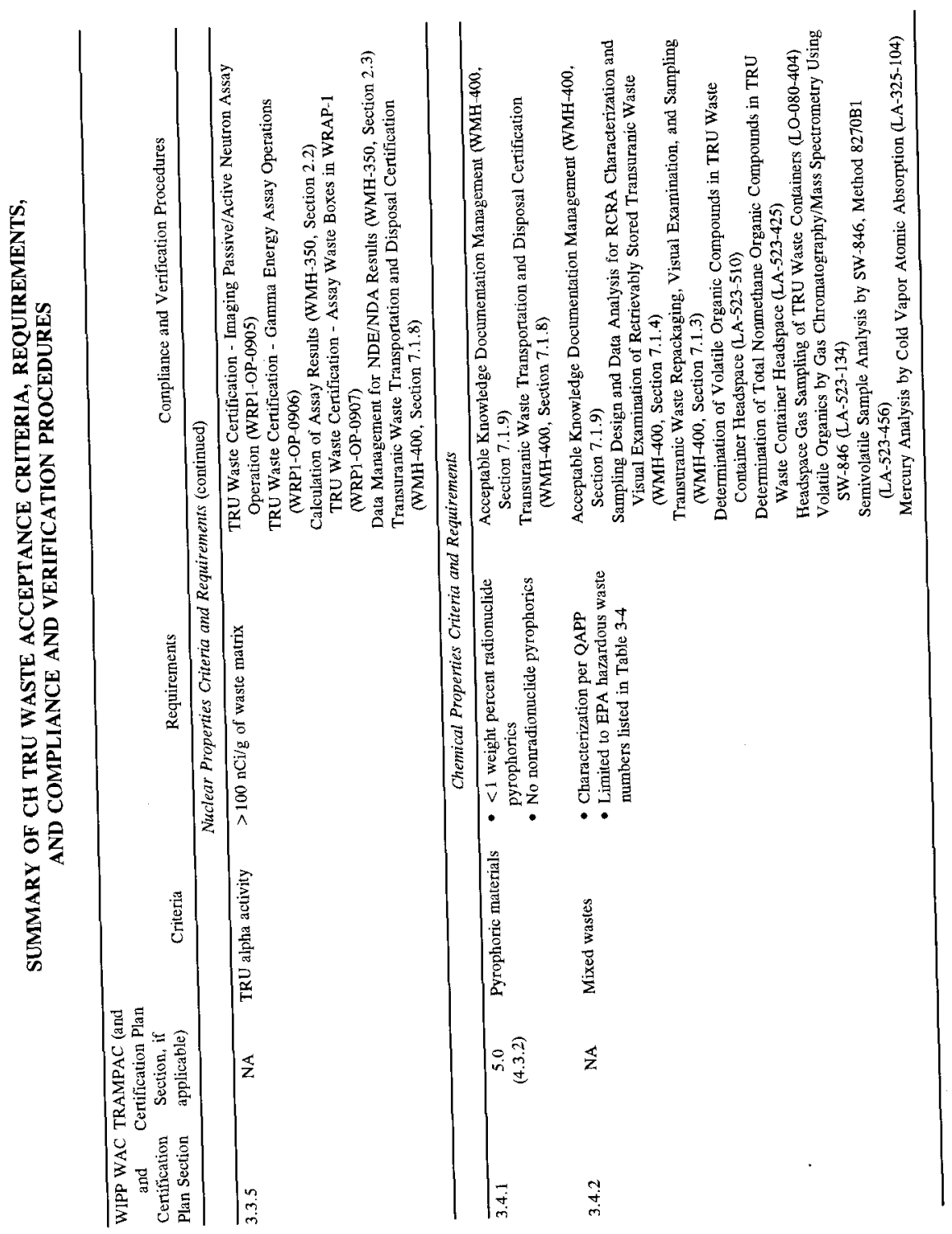


HNF-2600 Revision 0

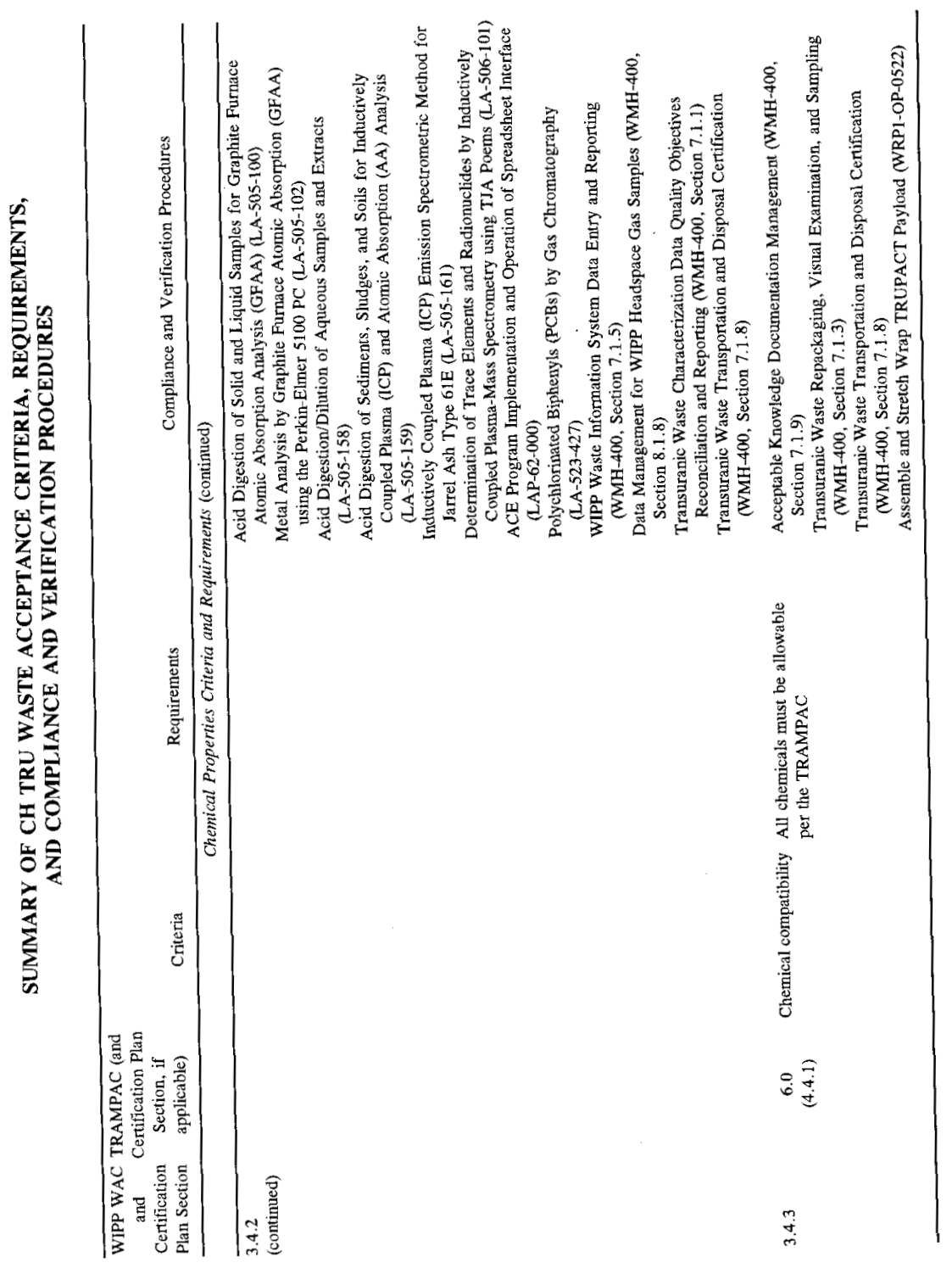




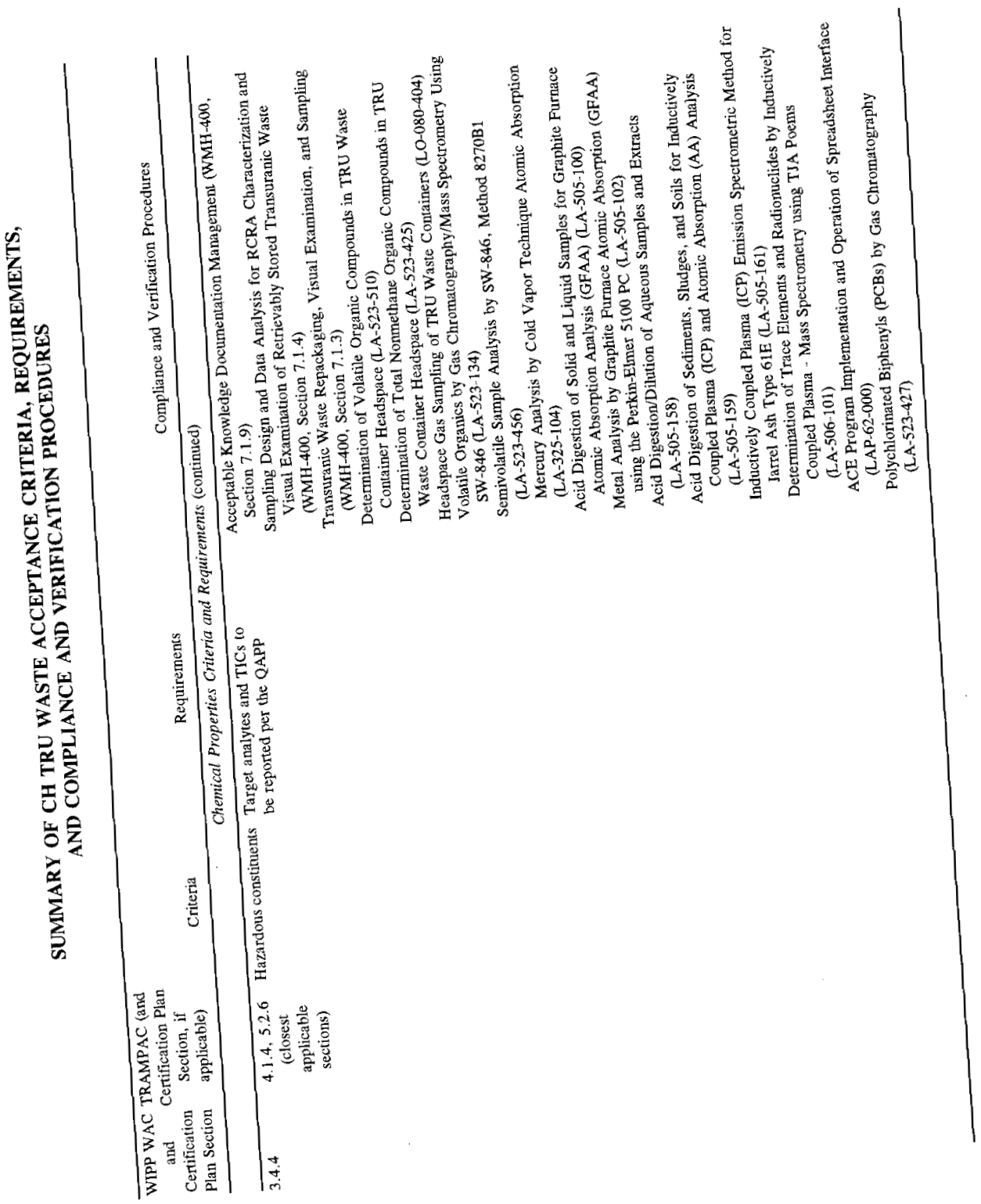


HNF-2600 Revision 0

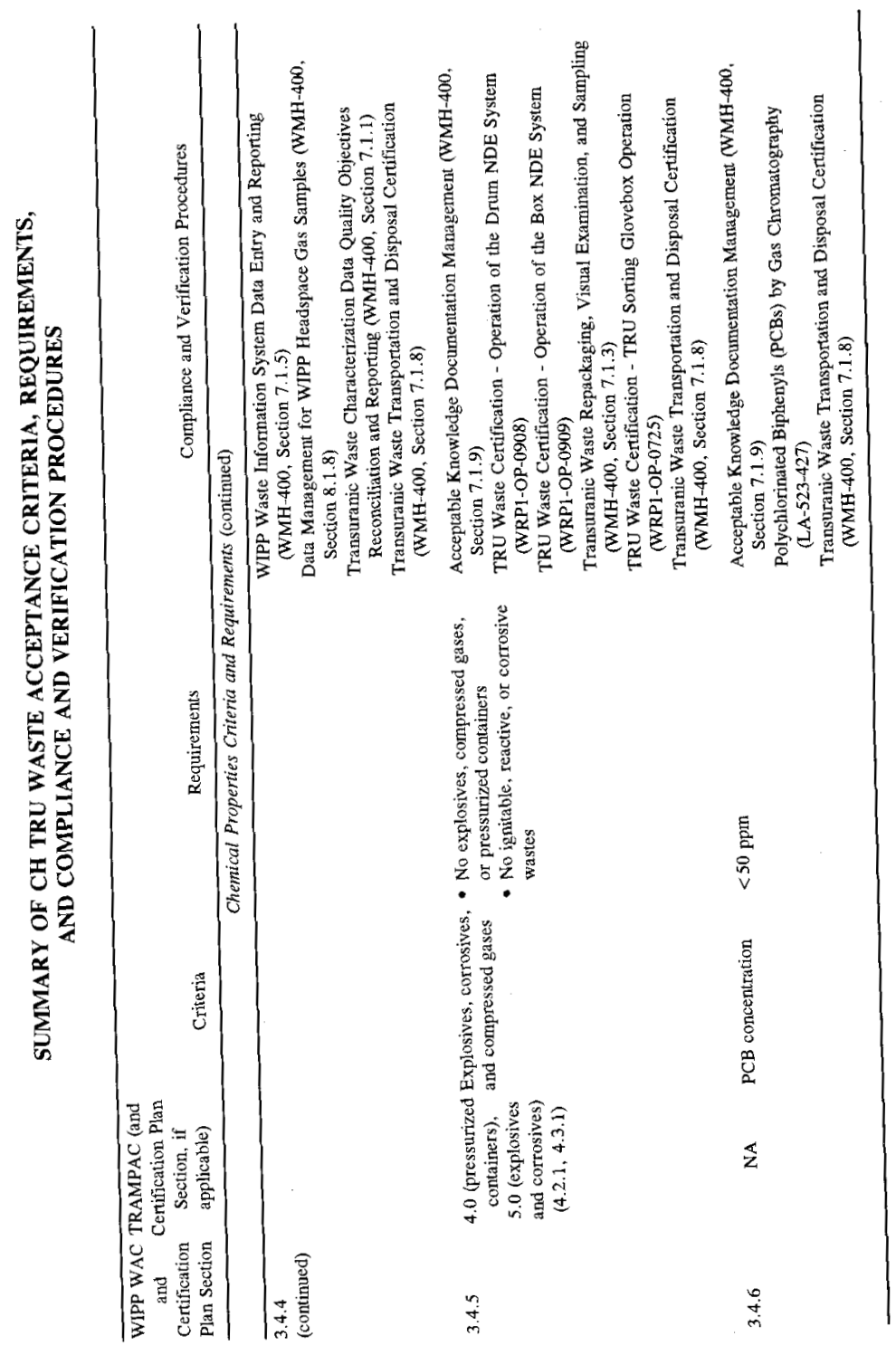


HNF-2600 Revision 0

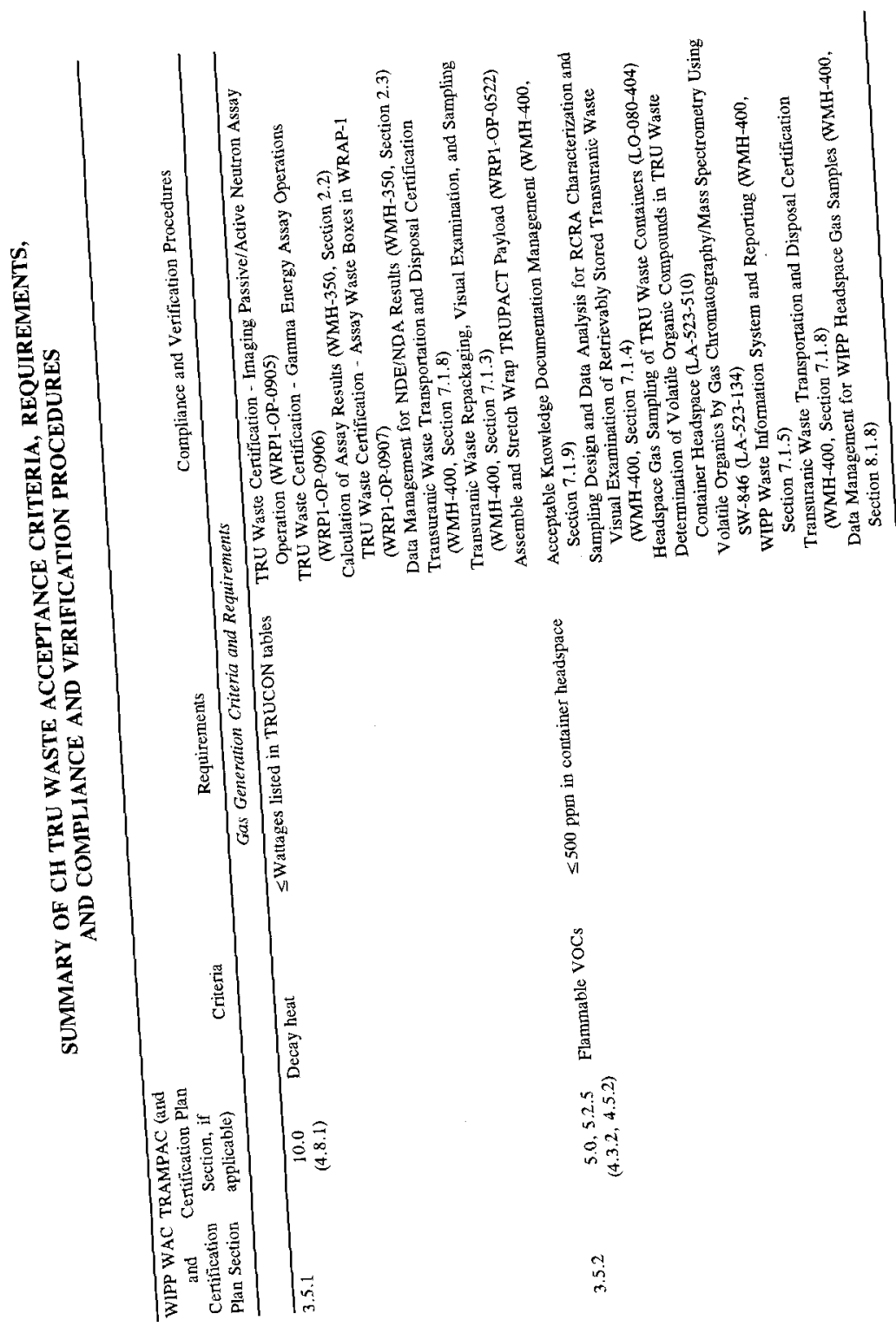

November 10, 1998 
HNF-2600 Revision 0

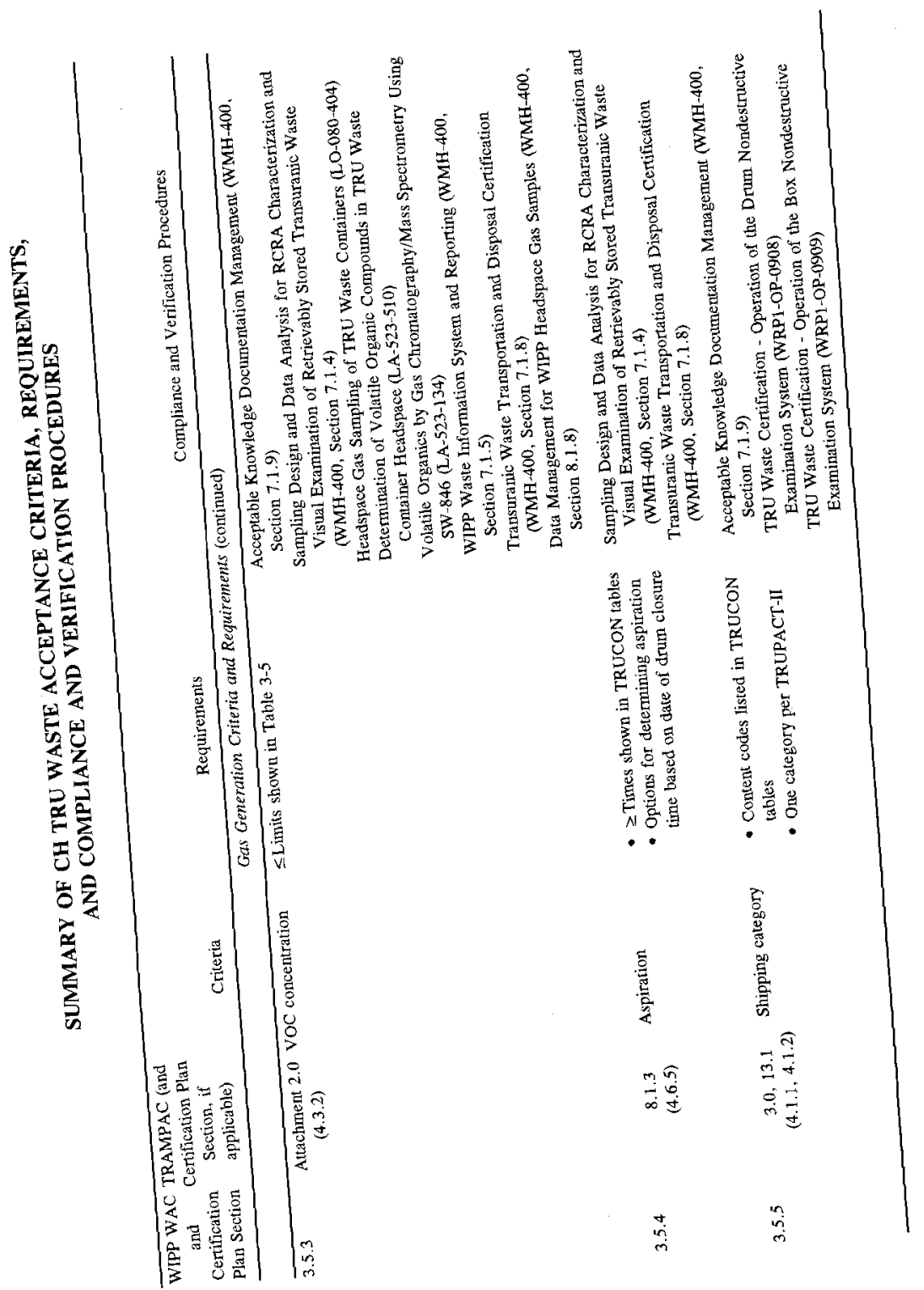

November 10, 1998 
HNF-2600 Revision 0

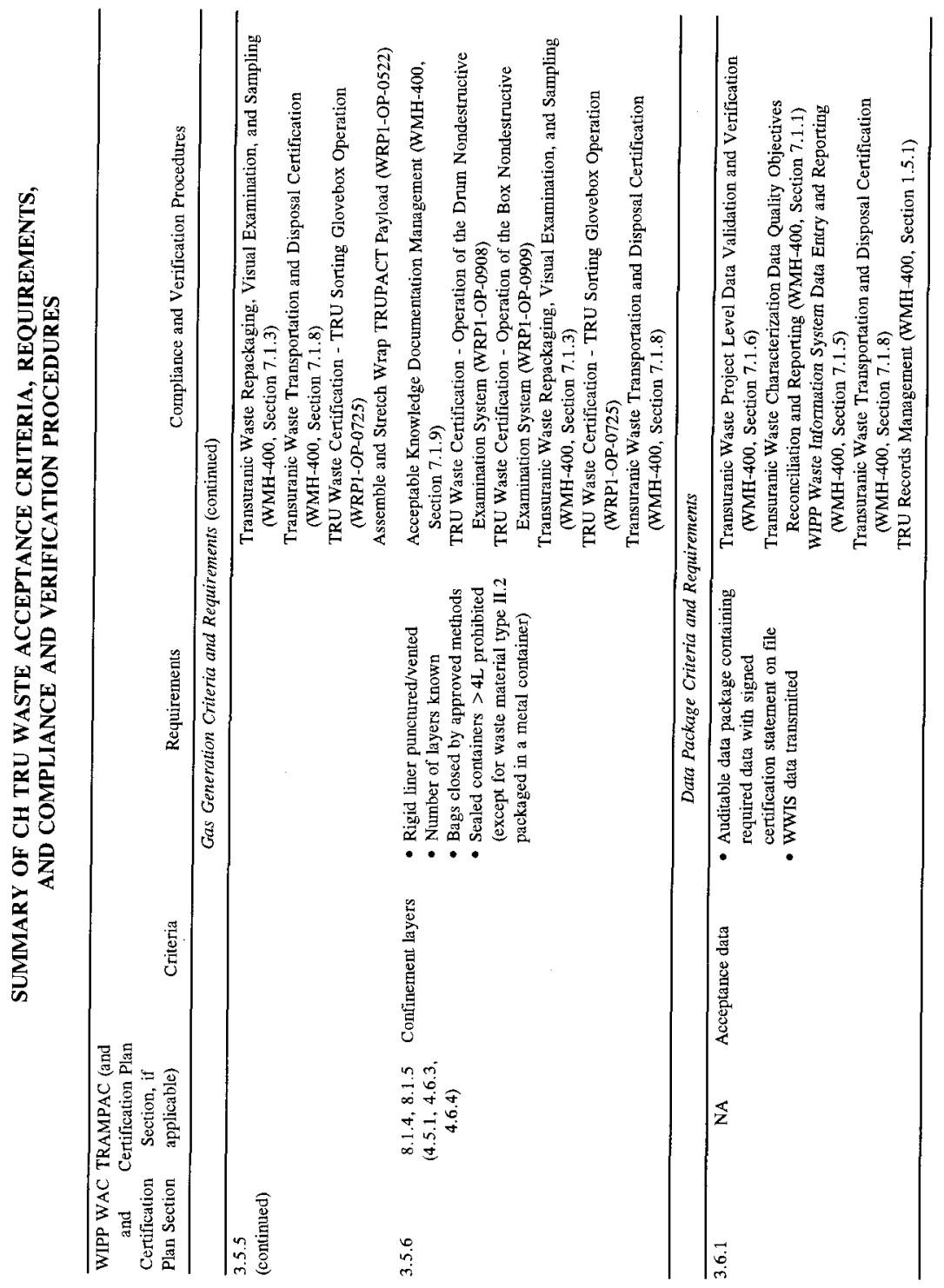


HNF-2600 Revision 0

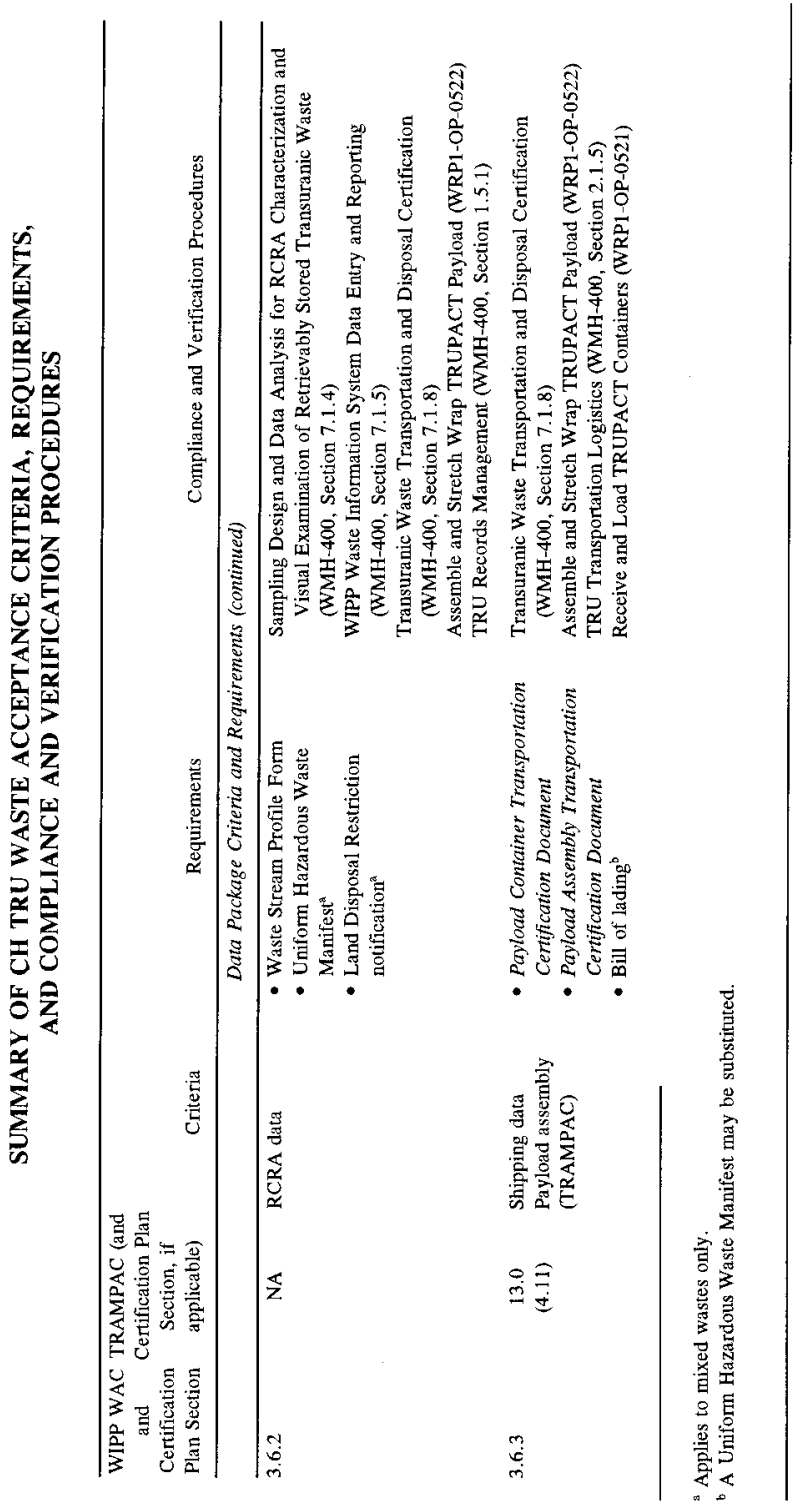


HNF-2600 Revision 0

\section{APPENDIX B}

\section{CH TRU WASTE CERTIFICATION CHECKLIST}


HNF-2600 Revision 0

\section{APPENDIX B}

\section{CH TRU WASTE CERTIFICATION CHECKLIST}

\section{CONTAINER ID NUMBER:}

Instructions: Review the documentation and visually inspect the container (if necessary) to verify that the waste and the container meet the requirements. Place a check in each applicable box if the requirement is met. Initial each criteria section if all requirements/limits of that section are met.

\begin{tabular}{|c|c|c|c|}
\hline Criteria & $\checkmark$ & Requirements/Limits & Initials \\
\hline Container Attribute & & - DOT Type A 55-gal, drum or SWBs & \\
\hline $\begin{array}{l}\text { Container/Assembly } \\
\text { Weight }\end{array}$ & & $\begin{array}{l}\bullet \leq 1000 \mathrm{hbs} / 55 \text {-gal. drum } \\
-\quad \leq 4000 \mathrm{lbs} / \mathrm{SWB} \\
-\quad \text { TRUPACT-II weight limits shown in Table } 3.2 .2 .2 \\
\text { of WIPP WAC, Current Revision }\end{array}$ & \\
\hline $\begin{array}{l}\text { Removable Surface } \\
\text { Contamination }\end{array}$ & & $\begin{array}{l}-\leq 20 \mathrm{dpm} / 100 \mathrm{~cm}^{2} \text { alpha } \\
-\leq 200 \mathrm{dpm} / 100 \mathrm{~cm}^{2} \text { beta-gamma (may be } 1000 \\
\left.\mathrm{dpm} / 100 \mathrm{~cm}^{2} \text { for certain isotopes [10 CFR } 835\right] \text { ) }\end{array}$ & \\
\hline Container Marking & & $\begin{array}{l}\text { - } \text { Bar Code } \\
\text { Shipping Category (Applies to TRUPACT-II payload } \\
\text { control only) }\end{array}$ & \\
\hline Dunnage & & - Empty 55-gal. drums or empty SWB & \\
\hline Filter Vents & & - Payload containers vented & \\
\hline Liquids & & $\begin{array}{l}- \\
-\quad<2 \mathrm{~L} \text { total residual liquid/55-gal. drum } \\
-\quad<8 \mathrm{~L} / \mathrm{SWB} \\
-\quad<1 \text { in. }(2.5 \mathrm{~cm}) \text { in the bottom of any container }\end{array}$ & \\
\hline $\begin{array}{l}\text { Nuclear Criticality } \\
\text { Pu-239 FGE }\end{array}$ & & $\begin{array}{l}\bullet \quad \leq 200 \mathrm{~g} / 55 \text {-gal. drum } \\
\bullet \quad \leq 325 \mathrm{~g} / \mathrm{SWB} \\
-\leq \text { TRUPACT-II limits shown in Table } 3.3 .1 .2 \text { of } \\
\text { WIPP WAC, Current Revision }\end{array}$ & \\
\hline $\begin{array}{l}\text { Pu-239 Equivalent } \\
\text { Activity }\end{array}$ & & $\begin{array}{l}\text { Untreated Waste } \\
-\leq 80 \mathrm{PE}-\mathrm{Ci} / 55 \text {-gal. drum } \\
-\leq 130 \mathrm{PE}-\mathrm{Ci} / \mathrm{SWB} \\
\leq 1800 \mathrm{PE}-\mathrm{Ci} / 55 \text {-gal. drum overpacked in } \mathrm{SWB} \text { or } \\
\text { TDOP } \\
\text { Solidified/Vitrified Waste } \\
-\leq 1800 \mathrm{PE}-\mathrm{Ci} / 55 \text {-gal. drum }\end{array}$ & \\
\hline Thermal Power & & $\begin{array}{l}\text { Reported if }>0.1 \mathrm{~W} / \mathrm{ft}^{3} \\
-<40 \mathrm{~W} / \mathrm{TR} \text { UPACT-II }\end{array}$ & \\
\hline Contact Dose Rate & & - $\leq 200 \mathrm{mrem} / \mathrm{hr}$ & \\
\hline
\end{tabular}


HNF-2600 Revision 0

\section{CH TRU WASTE CERTIFICATION CHECKLIST}

(continued)

\begin{tabular}{|c|c|c|c|}
\hline Criteria & $\checkmark$ & Requirements/Limits & Initials \\
\hline $\begin{array}{l}\text { TRU Alpha } \\
\text { Activity }\end{array}$ & & - $>100 \mathrm{nCi} / \mathrm{g}$ of waste matrix & \\
\hline $\begin{array}{l}\text { Pyrophoric } \\
\text { Materials }\end{array}$ & & $\begin{array}{l}\text { - <1 weight \% radionuclide pyrophorics } \\
\text { - No nonradionuclide pyrophorics }\end{array}$ & \\
\hline Mixed Waste & & $\begin{array}{l}\text { - Characterization per QAPP } \\
\text { - Limited to EPA hazardous waste numbers listed in } \\
\text { WIPP WAC, Current Revision, Table } 3.4 .2 .3-2\end{array}$ & \\
\hline $\begin{array}{l}\text { Chemical } \\
\text { Compatibility }\end{array}$ & & - Chemicals allowed by the CH TRAMPAC & \\
\hline $\begin{array}{l}\text { Hazardous } \\
\text { Constituents }\end{array}$ & & $\begin{array}{l}\text { - Target analytes and Tentatively Identified } \\
\text { Compounds reported per the QAPP }\end{array}$ & \\
\hline $\begin{array}{l}\text { Explosives, } \\
\text { Corrosives, and } \\
\text { Compressed Gases }\end{array}$ & & $\begin{array}{l}\text { - No compressed gases } \\
\text { - No ignitable, reactive, explosive, or corrosive waste }\end{array}$ & \\
\hline PCBs Concentration & & - $<50 \mathrm{ppm}$ & \\
\hline $\begin{array}{l}\text { Decay Heat } \\
\text { (TRUPACT-II } \\
\text { payload control } \\
\text { only) }\end{array}$ & & - $\leq$ Wattages listed in CH TRUCON tables & \\
\hline Flammable VOCs & & - $\leq 500 \mathrm{ppm}$ in container headspace & \\
\hline VOC Concentration & & $\begin{array}{l}\text { - } \leq \text { Limits listed in WIPP WAC, Current Revision, } \\
\text { Table 3.5.3.3 }\end{array}$ & \\
\hline $\begin{array}{l}\text { Aspiration } \\
\text { (TRUPACT-II } \\
\text { payload control } \\
\text { only) }\end{array}$ & & - $\geq$ Times listed in CH TRUCON tables & \\
\hline $\begin{array}{l}\text { Shipping Category } \\
\text { (TRUPACT-II } \\
\text { payload control } \\
\text { only) }\end{array}$ & & $\begin{array}{l}\text { - Content Codes listed in CH TRUCON tables } \\
\text { - One category per TRUPACT-II }\end{array}$ & \\
\hline $\begin{array}{l}\text { Confinement } \\
\text { Layers } \\
\text { (TRUPACT-II } \\
\text { payload control } \\
\text { only) }\end{array}$ & & $\begin{array}{l}\text { - Liner punctured/vented } \\
\text { - Number of layers known } \\
\text { - Bags closed by approved methods } \\
\text { - Sealed containers >4 L prohibited (except for waste } \\
\text { material Type II.2) }\end{array}$ & \\
\hline
\end{tabular}


HNF-2600 Revision 0

\section{CH TRU WASTE CERTIFICATION CHECKLIST}

(continued)

\begin{tabular}{|l|l|l|l|}
\hline \multicolumn{1}{|c|}{ Criteria } & $\checkmark$ & \multicolumn{1}{|c|}{ Requirements/Limits } & Initials \\
\hline Acceptance Data & & $\begin{array}{l}\text { - Auditable data package with signed Certification } \\
\text { Statement on file } \\
\text { - WWIS data transmitted }\end{array}$ & \\
\hline RCRA Data & $\begin{array}{l}\text { - Waste Stream Profile Form } \\
\text { - Uniform Hazardous Waste Manifest (mixed waste } \\
\text { only) } \\
\end{array}$ & $\begin{array}{l}\text { Land Disposal Restriction notification (mixed waste } \\
\text { only) }\end{array}$ & \\
\hline
\end{tabular}

I hereby certify that I have reviewed the data for this waste container and that they are complete and accurate to the best of my knowledge. I have determined that the data meet the requirements stated in the current revision of the WIPP WAC. I understand that this information will be made available to regulatory agencies and that there are significant penalties for knowingly submitting false information, including the possibility of fines and imprisonment.

Waste Certification Official Signature

$\widehat{\text { Date }}$

Initials

\begin{tabular}{|c|c|c|c|}
\hline Criteria & $\checkmark$ & Requirements/Limits & Initials \\
\hline Shipping Data & & $\begin{array}{l}\text { - TRUPACT-II Payload Container Transportation } \\
\text { Certification Document } \\
\text { - TRUPACT-II Payload Assembly Transportation } \\
\text { Certification Document } \\
\text { - Bill of Lading (Uniform Hazardous Waste Manifest } \\
\text { may be substituted) }\end{array}$ & \\
\hline
\end{tabular}

I hereby certify that I have reviewed the shipping data for this waste container and that they are complete and accurate to the best of my knowledge. I have determined that the data meet the requirements stated in the current revision of the WIPP WAC. I understand that this information will be made available to regulatory agencies and that there are significant penalties for knowingly submitting false information, including the possibility of fines and imprisonment.

Transportation Certification Official Signature 


\section{APPENDIX C}

PAYLOAD CONTAINER TRANSPORTATION CERTIFICATION DOCUMENT: ANALYTICAL PAYLOAD SHIPPING CATEGORY 
HNF-2600 Revision 0

APPENDIX C

TRUPACT-II PAYLOAD CONTAINER TRANSPORTATION

CERTIFICATION DOCUMENT (PCTCD)

(ANALYTICAL PAYLOAD SHIPPING CATEGORY)

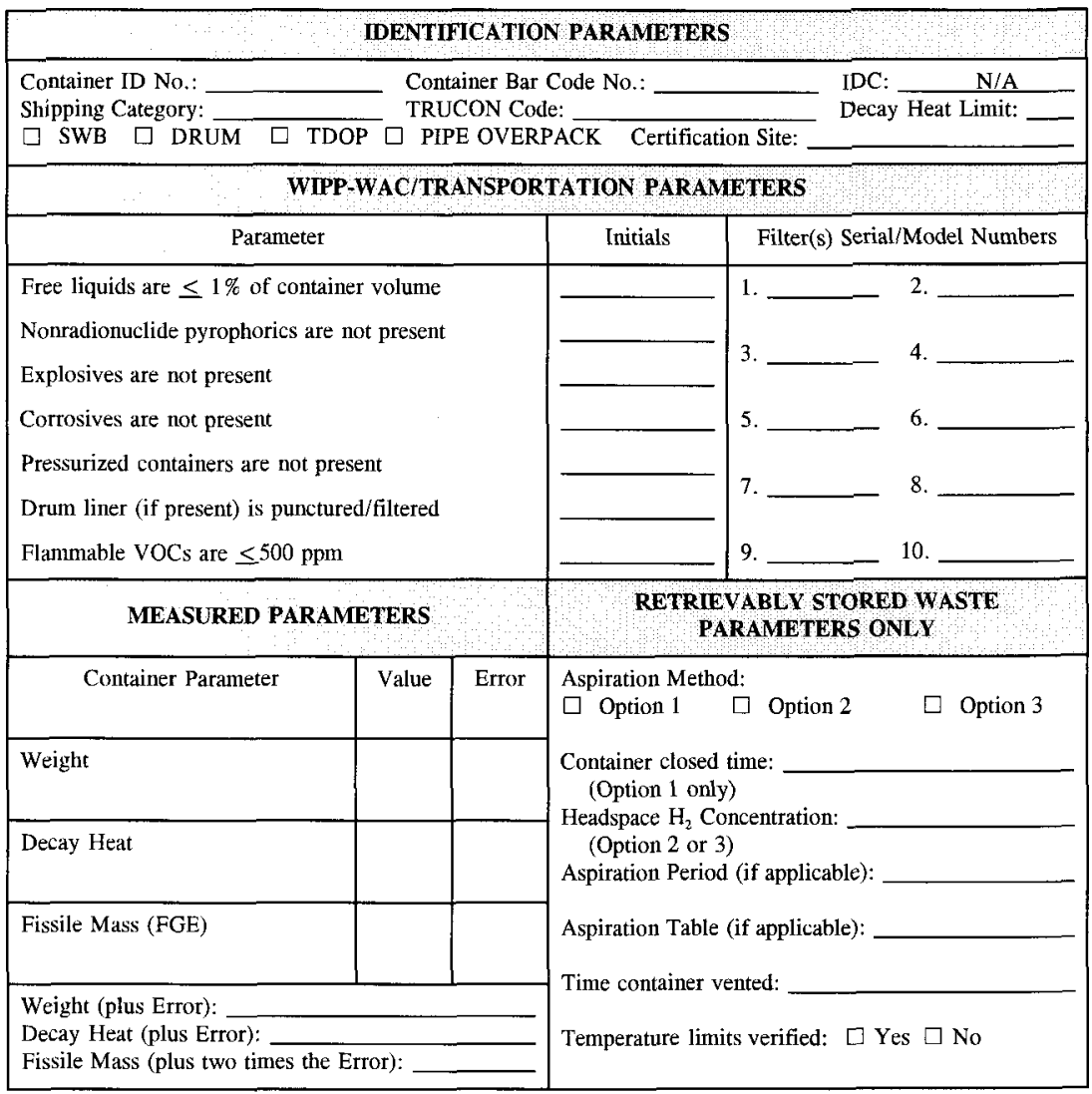

I certify that the above container meets all the requirements for shipment as stated in Appendix 1.3.7 of the Safety Analysis Report for the TRUPACT-II Shipping Package (current revision). The container is approved for shipment.

Transportation Certification Official

Date 
HNF-2600 Revision 0

APPENDIX D

PAYLOAD CONTAINER TRANSPORTATION CERTIFICATION DOCUMENT: TEST PAYLOAD SHIPPING CATEGORY 
HNF-2600 Revision 0

\section{APPENDIX D}

TRUPACT-II PAYLOAD CONTAINER TRANSPORTATION

CERTIFICATION DOCUMENT (PCTCD)

(TEST PAYLOAD SHIPPING CATEGORY)

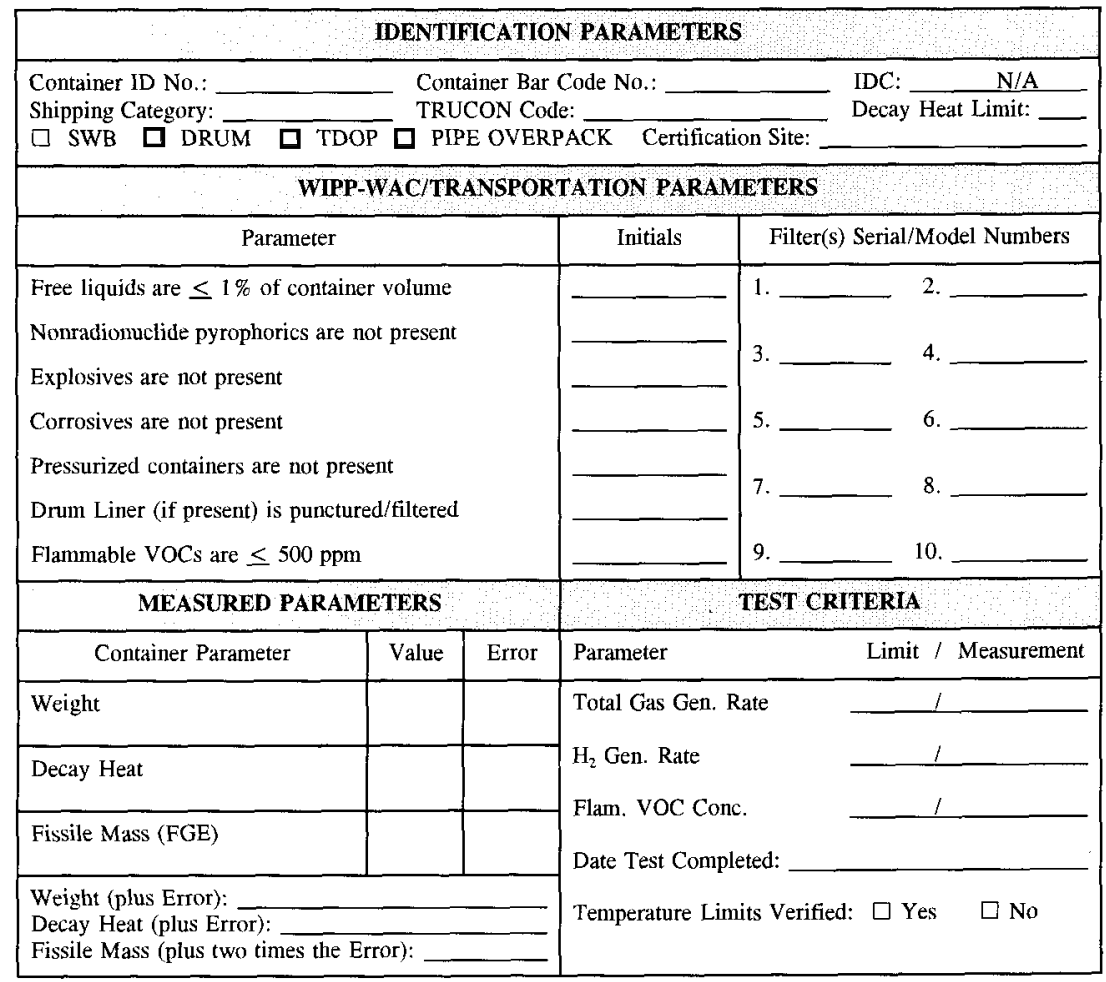

I certify that the above container meets all the requirements for shipment as stated in Appendix 1.3.7 of the Safety Analysis Report for the TRUPACT-II Shipping Package (current revision). The container is approved for shipment.

$\overline{\text { Transportation Certification Official }} \quad \overline{\text { Date }}$ 


\section{APPENDIX E}

\section{PAYLOAD ASSEMBLY TRANSPORTATION CERTIFICATION DOCUMENT}


HNF-2600 Revision 0

\section{APPENDIX E}

\section{TRUPACT-II PAYLOAD ASSEMBLY TRANSPORTATION CERTIFICATION DOCUMENT (PATCD)}

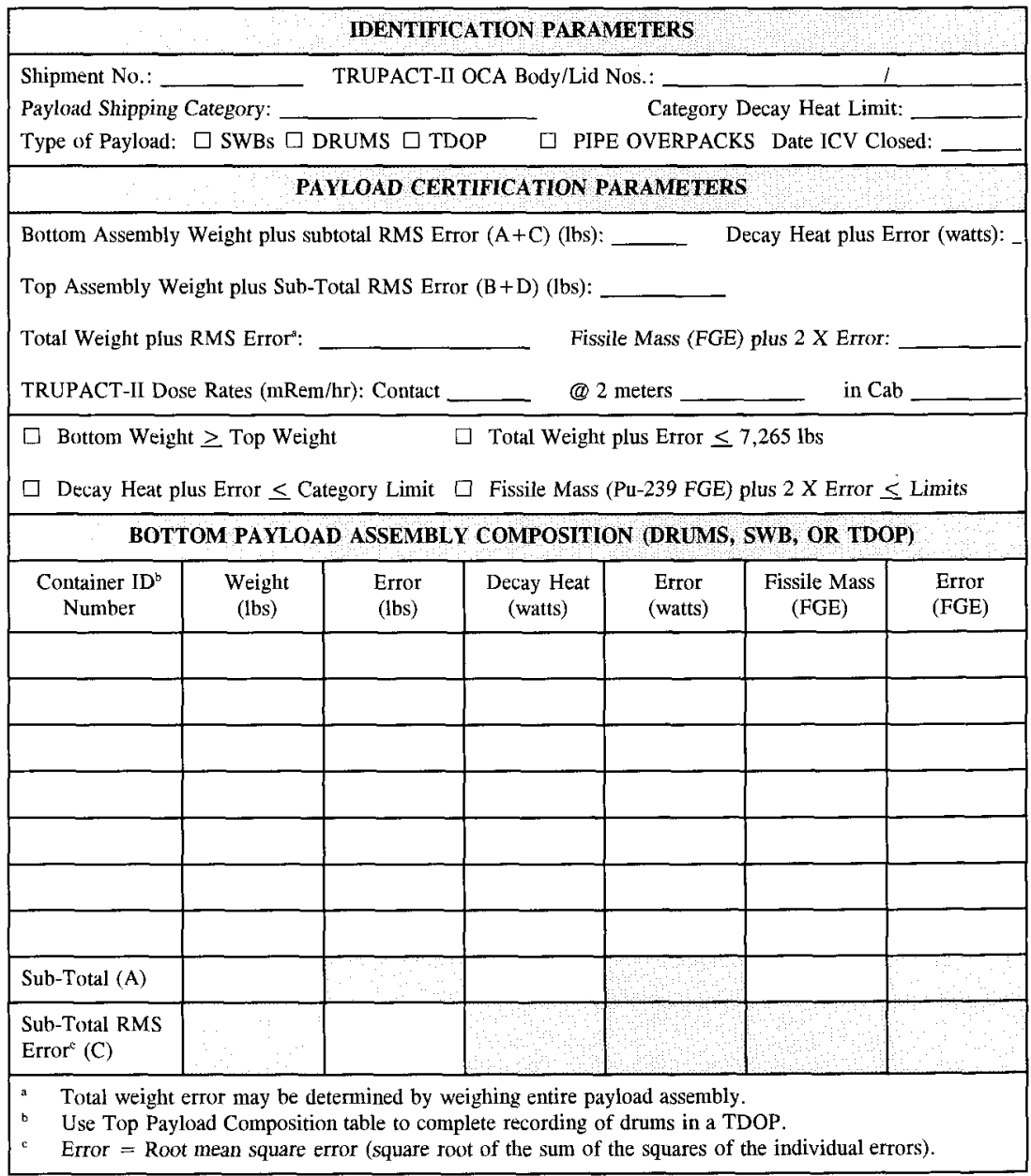


HNF-2600 Revision 0

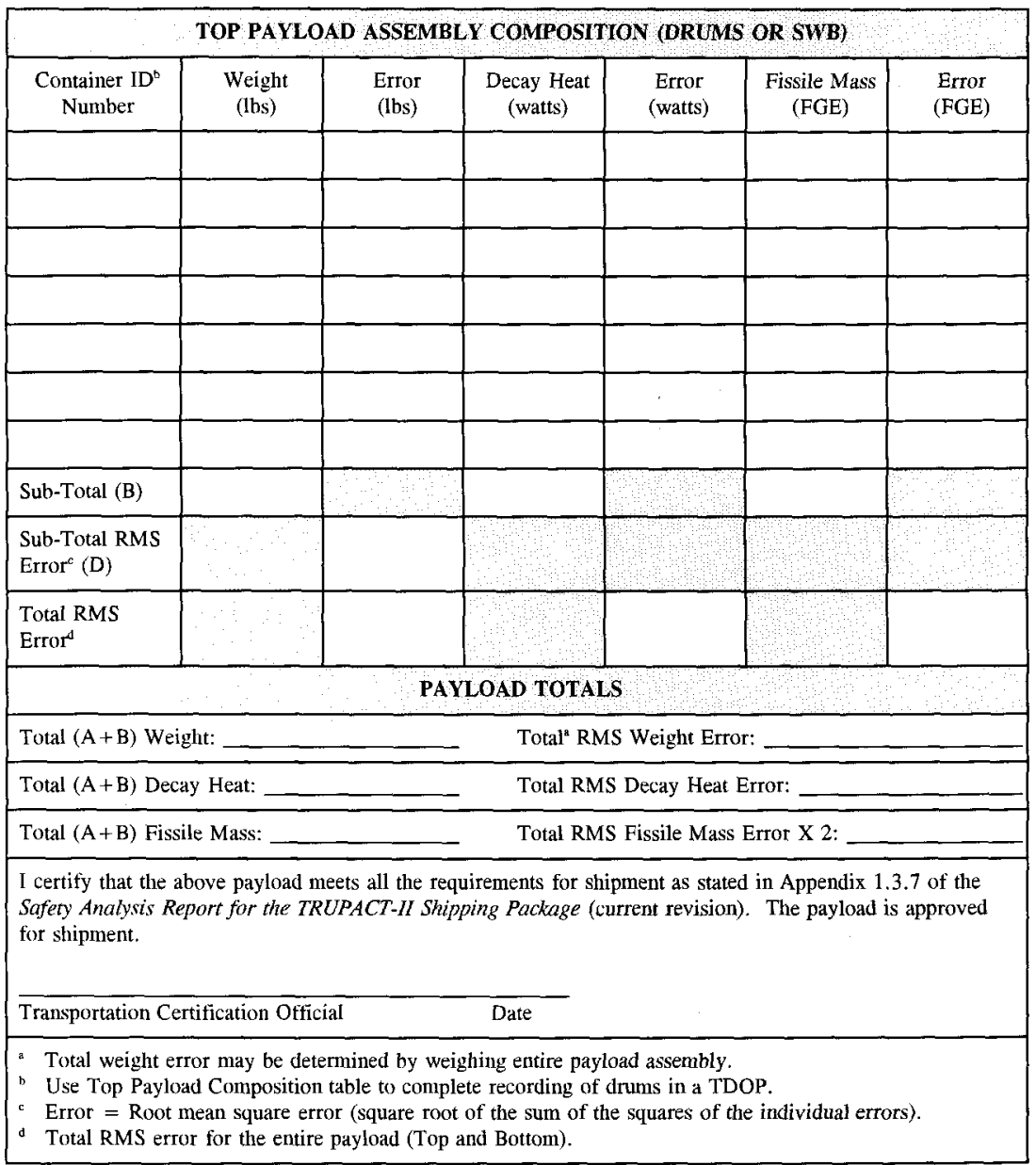




\section{DISTRIBUTION SHEET}

To

Distribution

From

TRU Waste Rrogram

\section{Project Title/Work Order}

HNE-2600, Hanford Site Transuranic Waste Certification Plan

\begin{tabular}{l} 
Page 1 of 1 \\
\hline Date $02 / 12 / 99$ \\
\hline EDT No. 625622 \\
ECN No. \\
\hline
\end{tabular}

Name

Tim Greager

Paul Crane

John C. MCCoy

Bill Jasen

Jim Maupin

Jennifer Cabaniss

Don Volkman

John Weidert

Lee $w$. Roberts

James Buckley

Dan Mantooth

DeYonne Southwick

Rich Clinton

Robert Bolls

Glen Triner

Cindy Girres

Ron Hadley

Tom Orgil1

Joyce McGuffey

Chuck Wolfe

Craig Wills

Dan Chase

Rampur Viswanath

Norm Willis

Susan stitt

Rhonda Connolly

Russ Bisping

Mark French

Bill Thackaberry

Melanie Myers

Engineering files

DOE/RL Reading Room

\begin{tabular}{|c|c|c|c|c|}
\hline MSIN & $\begin{array}{c}\text { Text } \\
\text { With All } \\
\text { Attach. }\end{array}$ & Text Only & $\begin{array}{c}\text { Attach.f } \\
\text { Appendix } \\
\text { Only }\end{array}$ & $\begin{array}{c}\text { EDT/ECN } \\
\text { Only }\end{array}$ \\
\hline T4-05 & $x$ & & & \\
\hline T 4-04 & $\mathrm{x}$ & & & \\
\hline $\mathrm{H} 1-15$ & $x$ & & & \\
\hline T4-05 & $x$ & & & \\
\hline T4-06 & $\mathrm{x}$ & & & \\
\hline $\mathrm{H} 1-15$ & $x$ & & & \\
\hline T3-05 & $x$ & & & \\
\hline $\mathrm{T} 4-52$ & $\mathrm{x}$ & & & \\
\hline $\mathrm{T} 4-51$ & $x$ & & & \\
\hline T3-04 & $x$ & & & \\
\hline$T 6-03$ & $\mathrm{x}$ & & & \\
\hline $53-30$ & $x$ & & & \\
\hline $\mathrm{T} 3-05$ & $\mathrm{x}$ & & & \\
\hline T3-05 & $x$ & & & \\
\hline T3-05 & $x$ & & & \\
\hline T3-01 & $x$ & & & \\
\hline $\mathrm{H} 6-33$ & $\mathrm{x}$ & & & \\
\hline $53-32$ & $\mathrm{x}$ & & & \\
\hline T3-05 & $x$ & & & \\
\hline T3-06 & $\mathrm{x}$ & & & \\
\hline$T 4-52$ & $x$ & & & \\
\hline $\mathrm{T} 4-52$ & $x$ & & & \\
\hline $53-90$ & $\mathrm{x}$ & & & \\
\hline$T 4-52$ & $x$ & & & \\
\hline T4-05 & $x$ & & & \\
\hline$T 4-05$ & $x$ & & & \\
\hline $\mathrm{N} 1-26$ & $\mathrm{x}$ & & & \\
\hline $57-55$ & $x$ & & & \\
\hline $\mathrm{T} 4-52$ & $x$ & & & \\
\hline $\mathrm{s} 3-90$ & $x$ & & & \\
\hline B1-07 & $x$ & & & \\
\hline $\mathrm{H} 2-53$ & $x$ & & & \\
\hline
\end{tabular}

